NBER WORKING PAPER SERIES

\title{
ON THE ECONOMICS OF AUDIT PARTNER TENURE AND ROTATION: EVIDENCE FROM PCAOB DATA
}

\author{
Brandon Gipper \\ Luzi Hail \\ Christian Leuz \\ Working Paper 24018 \\ http://www.nber.org/papers/w24018 \\ NATIONAL BUREAU OF ECONOMIC RESEARCH \\ 1050 Massachusetts Avenue \\ Cambridge, MA 02138
}

November 2017, Revised June 2018

This study uses proprietary PCAOB data. To access these data, we submitted a research proposal to the PCAOB describing the research questions, the research design as well as the data necessary to conduct the study. As a condition of data access, our study is reviewed by the PCAOB with respect to the release of nonpublic information (but not for its results). The PCAOB, as a matter of policy disclaims responsibility for any private publication or statement by any of its economic research fellows, advisors, and employees. The views expressed in this paper are the views of the authors and do not necessarily reflect the views of the Board, individual Board members, or staff of the PCAOB. Brandon Gipper was an Economic Research Fellow of the PCAOB. Christian Leuz is Economic Advisor of the PCAOB's Center of Economic and Risk Analysis. We appreciate the helpful comments of Preeti Choudhary, Michael Gurbutt, Robert Knechel, Luigi Zingales, PCAOB staff, two partners from one audit firm in our sample, and seminar participants at the PCAOB's Center for Economic Analysis and Stanford Summer Camp. The views expressed herein are those of the authors and do not necessarily reflect the views of the National Bureau of Economic Research.

NBER working papers are circulated for discussion and comment purposes. They have not been peer-reviewed or been subject to the review by the NBER Board of Directors that accompanies official NBER publications.

(C) 2017 by Brandon Gipper, Luzi Hail, and Christian Leuz. All rights reserved. Short sections of text, not to exceed two paragraphs, may be quoted without explicit permission provided that full credit, including $\odot$ notice, is given to the source. 
On the Economics of Audit Partner Tenure and Rotation: Evidence from PCAOB Data

Brandon Gipper, Luzi Hail, and Christian Leuz

NBER Working Paper No. 24018

November 2017, Revised June 2018

JEL No. G30,J44,J62,K22,L84,M21,M41,M42,M51,M54

\section{ABSTRACT}

This paper provides the first partner tenure and rotation analysis for a large cross-section of U.S. publicly listed firms over an extended period. We analyze the effects on audit quality as well as economic tradeoffs related to partner tenure and rotation with respect to audit hours and fees. On average, we find no evidence for audit quality declines over the tenure cycle and little support for fresh-look benefits after rotations. Nevertheless, partner rotations have significant economic consequences. We find increases in audit fees and decreases in audit hours over the tenure cycle, which differ by partner experience, client size, and competitiveness of the local audit market. More generally, our findings are consistent with efforts by the audit firms to minimize disruptions and audit failures around mandatory rotations. We also analyze special circumstances, such as audit firm switches and early partner rotations, and show that they are more disruptive than mandatory rotations, and also more likely to exhibit audit quality effects.

Brandon Gipper

Stanford University

Graduate School of Business

655 Knight Way

Stanford, CA 94305

gipperbr@stanford.edu

Luzi Hail

Wharton School

University of Pennsylvania

Locust Walk

Philadelphia, PA 19104

lhail@wharton.upenn.edu
Christian Leuz

Booth School of Business

University of Chicago

5807 S. Woodlawn Avenue

Chicago, IL 60637-1610

and NBER

cleuz@chicagobooth.edu 


\section{Introduction}

Does tenure of an audit partner at a given client influence audit quality? How disruptive and costly are partner rotations, say, in terms of audit hours and fees? Do audit firms rotate partners early when audit quality is low? Questions like these are central to audit practice and regulation and have been studied extensively in academic research (see, e.g., DeFond and Zhang, 2014, and Lennox and $\mathrm{Wu}, 2017$, for overviews). This literature recognizes information asymmetry, conflicts of interest, learning, and competition in audit market as key forces and highlights several economic tradeoffs. For instance, engagement partners with long tenure have developed close relationships with their clients, which could compromise audit quality or make them reluctant to update audit procedures. A partner that comes in after a rotation did not approve prior audit procedures and, hence, can take a "fresh look" at the engagement. Over the years, engagement partners develop a deeper understanding and specific knowledge of their clients and respective industries, which should enable them to perform audits better and more efficiently. Newly-assigned partners need time to acquire this knowledge, which is costly and could temporarily decrease audit quality. This short discussion highlights a myriad of potential effects.

Prior literature finds mixed evidence when it comes to the effects of partner tenure and rotation on audit quality. ${ }^{6}$ However, many of these studies rely on small samples obtained from individual audit firms or settings outside the U.S., where engagement partner names must be disclosed. It is not obvious that the results from foreign settings carry over to the U.S. where partner tenure and rotation have not been observable to outside investors until recently. In fact,

6 For instance, studies on the effects of mandatory partner rotation find decreases (Litt, Sharma, Simpson, and Tanyi, 2014), increases (Lennox, $\mathrm{Wu}$, and Zhang, 2014; and Laurion, Lawrence, and Ryans, 2016), and no change (Chi, Huang, Liao, and Xie, 2009) in audit quality. Studies on audit partner tenure find evidence of decreases (Carey and Simnett, 2006; Fitzgerald, Omer, and Thompson, 2018), increases (Chen, Lin, and Lin, 2008; Manry, Mock, and Turner, 2008), or an initial increase followed by a decrease (Chi and Huang, 2005) in audit quality. 
partner name disclosure could alter the effects of tenure and rotation. Moreover, the U.S. environment features major litigation risk for auditors, relatively strict audit oversight, including mandatory partner rotation every five years, as well as substantial monitoring by capital-market participants such as investors and analysts. These forces could substantially mitigate agency concerns relative to non-U.S. settings.

In this paper, we provide the first partner tenure and rotation analysis for a large crosssection of U.S. publicly listed issuers over an extended period (2008-2014). We analyze audit quality over the five-year tenure cycle, around partner rotations and as an impetus for early rotations. We also go back to first principles and study the underlying audit process and the economics of partner tenure and rotation. We shed light on how audit fees and hours evolve over the partner cycle and how the patterns differ with competitive pressures and partner experience. Our analysis provides novel evidence on the economic tradeoffs related to partner tenure and rotation for U.S. audit firms. Among other things, this evidence can serve as baseline for future research on the role of engagement partners using the disclosure of their names starting in 2017.

We use a proprietary dataset from the Public Company Accounting Oversight Board (PCAOB) that matches audit partners with client issuers. Aside from partner names and tenure, the dataset contains relevant engagement information, including total audit hours, partner hours, audit fees, billing realization, review partner names and hours, and internal audit risk ratings of the clients. Many of these data have not been previously analyzed for a large sample of U.S. firms. Our sample covers over 3,300 clients of six large U.S. auditors (henceforth "Big 6") ${ }^{7}$ from 2008 to 2014 and represents 46 percent of U.S. audit firms' clients covered by Audit Analytics

7 The six large audit firms are BDO USA, Deloitte \& Touche, Ernst \& Young, Grant Thornton, KPMG, and PwC PricewaterhouseCoopers. These firms are all subject to yearly PCAOB inspection and report partner and client data to the PCAOB annually in machine-readable form. Smaller audit firms are also required to report this information but do so with lower frequency (see Franzel, 2012). 
(85 percent in terms of market capitalization). The sample comprises more than 17,900 clientyear observations with 3,852 engagement-partner rotations (62 percent of which are from mandatory five-year rotations) and 431 audit-firm switches.

The analysis proceeds in several steps. We begin with audit quality, given a similar focus in prior work. We examine a large set of quality proxies (absolute accruals, restatements and their announcements, internal-control-weakness opinions, and PCAOB and audit-firm inspection findings). The nuances across proxies allow us to study various hypotheses related to partner tenure and around rotations (i.e., fresh look, learning, or capture). We show that, for the average engagement in our sample, audit quality is unrelated to partner tenure, except for the announcements of restatements, which are more frequent in the first two years after rotation (consistent with Laurion et al., 2017). Importantly, we show that this "no-result" is not a matter of power. Our tests could detect effects in absolute accruals as small as 7 basis points of total assets per year of the partner cycle, if they were present. As we examine different audit quality proxies, it is also unlikely that the no-result reflects measurement error. One potential reason for the difference in our findings compared to many prior U.S. (e.g., Manry et al., 2008; Litt et al., 2014; Fitzgerald et al., 2018) or foreign studies (e.g., Chen et al., 2008; Lennox et al., 2014) is that the large sample allows us to estimate "tight" models that include client, year, and audit firm tenure fixed effects, which should control for many of the confounds in audit quality analyses. Another plausible interpretation is that in the relatively robust U.S. reporting and audit environment the five-year rotation mandate is sufficiently short to prevent, on average, major declines in audit quality over the partner-tenure cycle.

In a next step, we examine several proxies related to the audit process. The goal is to shed light on the costs of partner rotations and to show how audit firms manage these transitions. 
Figure 1 summarizes the main insights from our analysis of audit fees, audit hours and partner hours. As the graph shows, we find a significant drop in audit fees in the initial year after partner rotation, but also systematic increases over the tenure cycle. At the same time, total audit hours and total partner hours as well as engagement partner hours exhibit a significant jump in year one of partner tenure, but revert to lower levels (audit hours and total partner hours) or steadily decrease (engagement partner hours) in the years that follow. Seeing these opposite trajectories for fees and hours is intuitive. When a new partner begins a five-year cycle, she needs to spend additional time familiarizing herself with the client and the audit procedures in place. She may also consider updating procedures or ask audit staff to help her with the transition. As the new partner does not yet have a relationship with the client, it could be harder for her to ask for fee increases. Moreover, the client could use partner rotation as a way to mount fee pressures.

We find rotation-related fee pressures to be more pronounced in competitive audit markets. When local audit markets are more concentrated, audit fees are, on average, lower and also relatively lower in the initial year after partner rotation. Over the rotation cycle, fees increase more in those markets. We find no differential relation in audit effort in competitive markets, suggesting that the result is due to (price) competition rather than unobservable differences in client types (which should be present in both fees and hours). The observed audit fee pattern is similar to the "low-balling" results around audit-firm switches (see Hay, Knechel, and Wong, 2006, for an overview). Yet, we document this pattern for partner rotation and partner tenure, in line with results in Bedard and Johnstone (2010) for planned audit hours and billing realization.

Combining the results for audit quality and audit hours suggests that U.S. audit firms exert extra effort to compensate the potential decline in audit quality in the initial years when a partner is new. The absence of "fresh look" benefits right after rotation is consistent with these findings 
and suggests that, on average, audit quality does not substantially decrease towards the end of the partner cycle, despite the sizeable decline in lead partner hours. Overall, the evidence for audit quality, fees, and hours is consistent with substantial transition management by the firms. In additional tests, we also look at non-audit fees, review partner hours, and billing realization.

We then examine a number of cross-sectional splits and special settings, in which audit quality concerns and fresh-look benefits as well as learning effects, disruptions, and economic tradeoffs may be more pronounced. Specifically, we consider (i) the arrival of new team members, (ii) differences in partner experience, (iii) differences in the complexity and size of clients, (iv) switches of the audit firm, (v) rotations of the audit team, and (vi) non-mandatory (or early) partner rotations before the five-year limit. We find that the arrival of new review partners or senior managers often occurs jointly with lead partner rotation, consistent with the existence of teams. We also show that these arrivals are disruptive, resulting in more total audit hours.

Next, we find that newer, less experienced partners exert more effort in the first year of the rotation cycle, but that they display greater declines in hours in years four and five, consistent with a steeper learning curve than experienced partners. Audit firms manage partner rotations for larger, complex clients differently. Consistent with anecdotal evidence that for such clients partner assignments are made far in advance so that new partners can "shadow" the outgoing partner ahead of the mandatory rotation, we find relatively higher total partner hours together with a reduction in engagement partner hours in the final year of the tenure cycle. We also do not see a significant jump in lead partner hours in the first year on a new engagement, as we do for smaller clients. Jointly, this pattern suggests that learning takes place earlier for large clients.

Disruptions and "fresh look" benefits of rotations could be much stronger when clients 
switch audit firms or when entire teams rotate off at the same time. ${ }^{8}$ Audit firm switches are rare events, occurring in only 2.3 percent of client-years. New clients require a substantial initial investment by the auditor and they likely exert pressure on fees (e.g., by initiating a bidding process). Supporting these ideas, we find that, for new audit firms, fees are substantially lower and audit hours are much higher in the first switch cycle (see also Bell, Causholli, and Knechel, 2015), not only compared to the previous audit firm but also relative to later partner cycles. However, the new auditor can recoup most of the initial fee discount and the extra hours over the first cycle. We also find a higher likelihood that (i) the new auditor issues an opinion indicating material control weaknesses and (ii) the PCAOB reports an inspection finding. The former result suggests fresh-look benefits when testing internal controls; the latter is consistent with lack of familiarity, learning, and the build-up of new systems for new clients. We find similar audit fee, hour, and quality effects after an audit team rotation (when the lead and review partner or senior manager jointly arrive), but the magnitudes are smaller, as one would expect. The likelihood that a client restates financials or announces a restatement, and the auditor provides a qualified 404b opinion is higher, consistent with fresh-look benefits when audit teams rotate.

Finally, we examine rotations before the five-year term limit. There are many reasons why a lead partner rotates early. Aside from personal motives, such as retirement, promotions, or illness, a client could pressure the audit firm to rotate the partner because of dissonances in the relationship or disagreements over certain accounting treatments. We are particularly interested whether audit quality events, such as PCAOB findings, lead to early partner rotations, especially given that partner names are not known. Our data shows that non-mandatory rotations are more frequent than previously thought (about 38 percent of all within-firm rotations). We find no

8 We acknowledge that these two rotation types are endogenous. They could reflect special circumstances such as poor client performance or aggressive reporting (e.g., Blouin, Grein, and Rountree, 2007). These circumstances at the client level could also affect audit quality and other audit variables in our analyses. 
incremental fee effects beyond mandatory rotations, but see small audit hour increases around early rotations, which can reflect concurrent (or persistent) quality issues or the unexpected nature of the rotation. With respect to audit quality, we generally find insignificant effects in the year after the non-mandatory rotation. However, in the year before, we find several significant audit quality associations. For instance, clients are more likely to restate their financials and to announce such a restatement. To sharpen our tests, we differentiate between early rotations that are explainable by retirements, promotions, office switches, or temporary leaves, and the remaining early rotations. We show that unexplained early rotations are more likely when an issuer restates the financials, announces a restatement, receives a qualified 404b opinion and after a PCAOB inspection finding (but not after audit firms' internal inspection findings). The effects are particularly pronounced for severe PCAOB inspection findings (e.g., when the inspection detects a likely GAAP departure). This evidence is novel and suggests that negative quality events give rise to early engagement partner rotations. We do not find any quality effects ahead of explainable rotations, lending further credence to this interpretation.

Our paper makes several contributions to the literature. We provide the first partner-tenure and rotation analysis for a large cross-section of publicly-traded U.S. issuers. Prior studies use proprietary data from individual audit firms (Manry et al., 2008; Bedard and Johnstone, 2010), survey data (Daugherty, Dickens, Hatfield, and Higgs, 2012), the introduction of the five-year rotation mandate (Litt et al., 2014; Sharma, Tanyi, and Litt, 2017), or disclosures of partner names in SEC comment letters (Laurion et al., 2017), resulting in fairly small and often selected U.S. issuer samples. ${ }^{9}$ Our large sample and the proprietary PCAOB data allow us to generate a number of novel insights into the economics of partner tenure and rotation. For instance, we add

\footnotetext{
9 An exception is Fitzgerald et al. (2018) who study a large sample of U.S. not-for-profit firms. For these entities,
} audit partner information is publicly available in Federal Audit Clearinghouse filings. 
to prior work by Bedard and Johnstone (2010) and Bell et al. (2015) and document fee pressures and extra hours around partner rotations, that audit firms compensate for these pressures and extra hours in subsequent years, without compromising audit quality, and that the fee effects differ depending on the competition in the local audit market. We also provide results consistent with partner learning and "shadowing" as well as new evidence for review partners. On a more descriptive level, we show that U.S. audit firms charge more for high-risk clients and spend more hours on them or that new review partners and senior managers join an engagement more often when the lead partner is new as well.

In contrast to many prior studies, we find limited audit quality effects over partner tenure and around rotation for the average U.S. engagement of Big-6 firms. This finding suggests that, on average, the mandated five-year rotation is short enough so that in the relatively robust U.S. environment we do not see major declines in audit quality over the partner cycle. However, we find associations with audit quality in instances that are potentially more disruptive (e.g., around audit firm switches and team rotations). We also show that low-quality audits, as evidenced by restatements or PCAOB findings, can give rise to early rotations and, in this sense, they have (career) consequences for partners (see also Aobdia and Petacchi, 2017).

\section{Conceptual underpinnings and prior literature}

\subsection{Institutional background and economic tradeoffs for audit quality, fees, and hours}

Partner rotation has been an important feature of U.S. audits for decades, dating back to the 1970s when the AICPA mandated rotation along with the peer review process for SEC Practice Section members. These new measures were largely a response to congressional investigations into the accounting industry in the mid-1970s (Zeff, 2003). Prior to Sarbanes Oxley (SOX), lead 
partners had to rotate at the latest after seven years and then had a two-year "cooling-off" period before they could again become the lead partner for the same engagement. ${ }^{10}$ The idea was that rotation would make it less likely that audit quality suffers because the lead partner and the client developed a close relationship and also that rotation would provide a new perspective on the engagement, so-called "fresh-look" benefits. ${ }^{11}$ Partner rotation, like many other features of the U.S. audit regime, came under scrutiny in the wake of Enron's bankruptcy and Arthur Andersen's demise. SOX reduced the maximum term for lead and review (also called “concurring") partners (Section 203). SEC rules implementing SOX Section 203 stipulate that the engagement and review partners are required to rotate off an engagement after five consecutive years in either capacity and, upon rotation, must be off the engagement for five years (17 C.F.R. $§ 210.2-01(c)(6))$. The rules came into effect for fiscal years beginning after May 2003 for lead partners and a year later for review partners. ${ }^{12}$ In their comment letters to the SEC regarding the implementation of Section 203, many large audit firms expressed support for the goals of rotation, highlighting the importance of fresh-look benefits, but often recommended

10 The AICPA rule stated a limit of five consecutive years as the norm but allowed for several exceptions. For instance, in unusual circumstances, a firm's chief executive partner (or designee) was allowed to grant a two-year extension so long as there was an in-depth supplemental review by another partner (AICPA, 1978).

11 The term "fresh look" and its economic intuition are not well defined in the literature. DeFond and Zhang (2014) discuss it in the context of mandated audit firm rotation (e.g., Section 5.2.1.1). Lennox and Wu (2017) use the term when discussing papers that find results consistent with "fresh look" in the context of mandatory partner rotation. SEC Chairman Harvey Pitt (2002) appears to be one of the first to use the phrase in Senate testimony.

12 The wording of the rule "fiscal years beginning after May 2003" implies that if the current lead partner's tenure equals or exceeds five years for the first fiscal year ending after May 2003, the partner must rotate the following year. For example, if 2003 is the lead partner's fifth year auditing a December 31 client, the partner will rotate, and a new partner will begin in 2004. This implementation could contribute to a relatively large number of fiveyear rotations of lead partners after 2008 and of review partners after 2009 (see Table 1, Panel B, for descriptive statistics). We use assumptions to expand the partner history data in the early years of our sample (i.e., we assume a fifth-year rotation prior to an observed switch). This assumption could also contribute to a larger number of five-year rotations in 2008. 
shorter cooling-off periods, especially for review partners. ${ }^{13}$ These comment letters also emphasized that client-specific knowledge and audit-team continuity can improve audit quality.

The letters and regulatory debate point to a number of important economic tradeoffs in auditing, which have been known for a long time (see also DeAngelo, 1981; Watts and Zimmerman, 1983). On one hand, long-term relationships can lead to agency concerns. Over time, the lead partner could become less vigilant. Moreover, the engagement partner could develop a personal relationship with management, which could compromise independence and, in turn, reduce audit quality (e.g., Bamber and Iyer, 2007). Frequent rotation makes it harder for personal relationships to form. In addition, the incoming partner is not (or less) tied to prior reporting choices or audit procedures, which could bring fresh-look benefits and greater independence, and lead to better audit quality (e.g., Hamilton, Ruddock, Stokes, and Taylor, 2005). On the other hand, engagements can be very complex, with clients operating businesses around the world having myriad types of transactions. Over time, partners learn about these complexities through repeated audits. This client-specific knowledge can improve audit quality (e.g., Beck, Frecka, and Solomon, 1988; Knapp, 1991). Incoming partners lack client-specific knowledge and need time to acquire it. Partner rotation likely disrupts this built-up knowledge and, hence, could lower audit quality, at least, until the new incoming partner is up to speed.

These economic tradeoffs make the pattern of audit quality over the engagement partner cycle and around rotation not obvious. Specifically, fresh-look benefits and partner capture suggest an initial increase and then a decrease in audit quality over the partner's tenure. Learning

${ }^{13}$ See, e.g., Deloitte (2003), Ernst \& Young (2003), KPMG (2003), PricewaterhouseCoopers (2003). However, other commentators (e.g., Turner, 2003) pointed out that shorter cooling-off periods can allow partners to bridge cycles between lead partner positions with the same client in a role described as "relationship partner." 
effects go in the opposite direction and predict an increase in audit quality over the tenure cycle. Similar tradeoffs and forces apply to the review partner on an engagement.

However, it is important to recognize that there are other economic and institutional forces affecting financial reporting and audit quality. In the U.S., clients and audit firms face strong capital-market forces, for instance, monitoring by analysts and investors. In addition, there is substantial regulatory oversight by the SEC and the PCAOB. These forces could mitigate the aforementioned agency concerns in auditing and, hence, attenuate tenure effects. Moreover, audit firms can take actions to reduce disruptions from rotation events. They can put client-specific systems in place, have the incoming partner "shadow" the outgoing one, and keep the audit team (e.g., senior managers) in place when the lead or the review partner rotate. These actions likely attenuate the learning effects that one would otherwise see around rotation or over the cycle.

The described tradeoffs are not only relevant for audit quality but should also be related to audit pricing, that is, competitive pressures around rotations and audit fee management over the tenure cycle. For instance, as the incoming partner knows the client management or audit committee less well, it could be harder for her to push for fee increases. Similarly, it is conceivable that clients actively use partner rotations as an apt time to renegotiate audit fees or to explore outside options for their audit, which would likely generate fee pressures to retain the client. These effects could depend on the competition in the local audit market. Specifically, clients headquartered in more competitive markets are likely to have lower audit fees, all else equal, and could see larger fee cuts around rotation. It is conceivable that audit firms attempt to recoup fee pressures around rotation with larger subsequent increases over the tenure cycle.

Aside from fees, we expect that the discussed economic tradeoffs manifest in audit effort as measured in audit hours and partner hours. For example, the described learning effects predict 
increases in audit and partner hours in the early years after rotation. Careful rotation management or partner shadowing could dampen such effects and instead increase partner hours towards the end of the tenure cycle. Studying the underlying audit process variables like partner hours should facilitate the interpretation of observed changes in audit quality.

\subsection{Prior literature and $P C A O B$ partner data}

There exists an extensive literature on partner tenure and rotation, primarily focusing on reporting and/or audit quality. A small subset of studies performs analyses using audit fees or audit hours. Audit hours are usually not publicly available and, hence, less commonly studied. ${ }^{14}$ Studies based on U.S. auditors tend to have relatively small samples, either made available by an audit firm or obtained by making assumptions about rotations observed in other sources (e.g., SEC comment letter responses). Studies with foreign samples rely on partner name disclosure, which are mandated in several countries. We briefly summarize this prior work, differentiating between studies on U.S. and foreign auditors.

In the U.S., Manry et al. (2008) and Bedard and Johnstone (2010) obtain private samples from undisclosed audit firms. Manry et al. (2008) have 90 observations and find that discretionary accruals decrease as partner tenure increases, consistent with an increase in audit quality over the cycle. Bedard and Johnstone (2010) examine planned audit hours and planned billing realization for over 500 observations. They find that planned hours increase and planned realization declines for an incoming partner. This evidence is consistent with learning, but the authors caution that, without measures of audit quality, it is not possible to disentangle learning over the tenure cycle from "decreased skepticism, with negative implications for audit quality."

${ }^{14}$ E.g., Cameran, Francis, Marra, and Pettinicchio (2014) use public fee data and proprietary hour data from audit firms in Italy. Kwon, Lim, and Simnett (2010) examine hours and fees around mandatory audit firm rotation in South Korea; they find evidence for low-balling effects and startup costs as predicted by DeAngelo (1981). 
Fitzgerald et al. (2018) examine internal control opinions for not-for-profit entities receiving federal funds, as these entities have to obtain internal control audits, for which the engagement partners are identified. They find results consistent with partner capture. ${ }^{15}$ Laurion et al. (2017) use partner names disclosed in SEC comment letter responses to infer rotations. Examining restatement announcements, they find results consistent with fresh-look benefits. Litt et al. (2014) and Sharma et al. (2017) examine clients that have recently changed audit firms and assume that partners rotate only after five years. ${ }^{16}$ Litt et al. (2014) find evidence based on discretionary accruals and going-concern opinions suggesting lower reporting quality following the assumed rotation. Sharma et al. (2017) find higher audit fees following the assumed rotation and longer reporting lags, consistent with learning effects for incoming partners and with rotations being disruptive (but inconsistent with the notion of fee pressure around rotation).

Outside the U.S., studies examine partner tenure and rotation in countries such as Australia, China, Germany, Italy, and Taiwan. Rotation mandates differed across these countries in the past but have largely converged following SOX. At this point, most countries have five-year cycles, though studies' sample periods often predate these changes and may cover longer tenures. Results are mixed, even within the same country and over relatively similar time periods. Some studies find results consistent with fresh-look benefits after rotation and partner capture over the cycle (e.g., Hamilton et al., 2005; Carey and Simnett, 2006; Fargher, Lee, and Mande, 2008; Chi et al., 2009; Firth, Rui, and Wu, 2012; Gold, Lindscheid, Pott, and Watrin, 2012; Lennox et al., 2014). Others find results consistent with learning and experience benefits that come along with tenure (e.g., Chen et al., 2008; Gold et al., 2012; Azizkhani, Monroe, and Shailer, 2013; Cameran et al., 2014; Lennox et al., 2014).

\footnotetext{
${ }^{15}$ Partner rotation is not mandatory for not-for-profit entities. Audit firms generally have internal policies that rotate the partner after seven years, though not all firms have such policies.

${ }^{16}$ We find that rotations before year five are relatively frequent (see Table 1, Panel B), questioning this assumption.
} 
In contrast to prior work, we examine a large sample of U.S. public issuer engagements by six large, annually-inspected audit firms. As lead and review partner names were not disclosed in the U.S. over our sample period, we rely on a proprietary dataset provided by the PCAOB. SOX authorizes the PCAOB to inspect audit firms of SEC registrants. As part of the inspection process, the PCAOB collects data on audit engagements. The PCAOB obtains data from the audit firms through an annual data request and the inspection process (e.g., CAQ, 2012). It uses these data in a variety of ways related to its oversight mission, including the selection of engagements for inspections. We exploit confidential data that were previously unavailable to academic research (e.g., partner names, partner hours, admission year to the partnership, etc.). A key difference to extant studies on foreign audit markets is the confidentiality of partner names in the U.S. This feature allows us to study tenure and rotation effects that are largely unaffected by partner name disclosures and the ensuing reputation effects.

\section{Research design and sample description}

\subsection{Research design}

To empirically examine the audit partner tenure and rotation effects we estimate the following Ordinary Least Squares (OLS) regression model:

Audit Quality / Audit Economics $s_{i, t}=\beta_{0}+\beta_{1} \times$ Partner Tenure $_{i, t}+\sum \beta_{\mathrm{m}}$ Audit-specific

Controls $_{i, t}+\sum \beta_{\mathrm{n}}$ Client-specific Controls $_{i, t}+\sum \beta_{\mathrm{k}}$ Fixed Effects $_{i, t}+\varepsilon_{i, t}$.

The dependent variables are various proxies for audit quality and variables related to the process and the economics of audits for client $i$ in fiscal year $t$. We discuss these proxies in more detail below. The primary test variable is Partner Tenure, a count variable reflecting the number of years, one through five, the lead partner has spent on the engagement. The coefficient estimate $\beta_{1}$ indicates the trend in the regression's left-hand side variable over the lead partner's tenure 
after controlling for all the other variables included in the model. In some specifications, we replace Partner Tenure with a series of binary indicators, Tenure Year 1 to 5, to map out the effects over the tenure cycle giving rise to the following version of the model in Eq. (1):

Audit Quality / Audit Economics $i, t=\beta_{0}+\beta_{1} \times$ Tenure Year $1_{i, t}+\beta_{2} \times$ Tenure Year $2_{i, t}+\beta_{4} \times$ Tenure Year $4_{i, t}+\beta_{5} \times$ Tenure Year $5_{i, t}+\sum \beta_{\mathrm{m}}$ Audit-specific Controls $\mathrm{s}_{i, t}+\sum \beta_{\mathrm{n}}$ Clientspecific Controls $_{i, t}+\sum \beta_{\mathrm{k}}$ Fixed Effects $\mathrm{E}_{i, t}+\varepsilon_{i, t}$.

The variable Tenure Year 3 serves as base period (i.e., no coefficient estimate) and the coefficients $\beta_{1}$ to $\beta_{5}$ measure the incremental effects of a particular year in the tenure cycle.

We construct the Partner Tenure variable using the partner names and identifiers in the PCAOB database. Because this dataset comes in a non-standardized format, we apply the following protocol: (i) we match on all available names and identifiers to construct a time series of individual partners, and then use this panel to identify within-client partner rotations and to count the number of tenure years. ${ }^{17}$ (ii) We use the information on planned, upcoming partner tenure years provided by the audit firm to fill existing gaps in the panel and to cross-check the observed tenure year count from (i). ${ }^{18}$ For instance, if we have data on the upcoming partner in a non-populated year for client $i$, we use this information to count up or down when data is missing or disagrees in the adjacent years. (iii) We fill in missing years under the assumption that a partner completes the entire five-year cycle. This procedure allows us to extend the sample by

\footnotetext{
${ }^{17}$ Matching on reported names is inherently noisy. For Partner Tenure, we match on family name alone. But it is still possible that some common names within an audit firm (e.g., "Smith") match even though they stem from different partners. Through manual inspection, we observe no cases where matching family names leads to a tenure cycle exceeding five years. Moreover, matching on family names misses family name changes or different spellings identifying the same person (e.g. "Smith" in 2008 and "Smiht" in 2009). As sensitivity check, we perform a "fuzzy" match and find fewer than 10 cases with misspellings. Thus, we believe that, on balance, precisely matching the last names dominates, as there are many close family name spellings that represent different individuals (e.g. "Johns" in 2008 and "Johnson" in 2009).

18 Audit firms do not report upcoming partner(s) for all years in our series. If there is a mismatch between "planned" partner and subsequent, observed lead partner (in about 2.6 percent of cases), we treat it as a non-mandatory partner rotation. It could also be related to an audit firm switch.
} 
back-filling tenure cycles early in the sample period when, for instance, we only observe the last year of an outgoing partner on the engagement. ${ }^{19}$

The models in Eq. (1) and (2) contain an extensive set of control variables. First, we include variables specific to the audit engagement that are primarily drawn from the PCAOB dataset. We use the Client Risk Rating, which audit firms assign to their clients early in the audit planning process (e.g., in April or May for large, December year-end clients). Including this proxy should help us isolate audit quality if audit firms give higher risk ratings to clients with lower reporting quality. As every audit firm has its own risk rating system, we normalize ratings by forming rank-ordered quintiles per audit firm with higher values marking higher perceived audit risk. Due to variation in the granularity of risk ratings, not all audit firms have clients in all quintiles. In the audit fee regressions, we include Audit Hours as a control. The variable reflects all hours performed by staff and partners on the engagement of client $i$ in year $t$. However, given the endogenous nature of audit hours (e.g., Copley, Gaver, and Gaver, 1995), we refrain from interpreting the coefficient estimates on audit hours in the fee regressions.

Second, we include multiple client characteristics as controls in the model. We follow prior literature (e.g., Minutti-Meza, 2013, for audit quality; Ball, Jayaraman, and Shivakumar, 2012, for audit economics) and include variables such as firm size, leverage, profitability, growth opportunities, all drawn from Compustat. Finally, we include an extensive fixed-effects structure. Most models include client, year, and audit firm tenure fixed effects. The latter represent the number of consecutive years the client is with the same audit firm (e.g., Johnson, Khurana, and Reynolds, 2002; Bell et al., 2015). Client fixed effects are important as they

19 Assumption (iii) will over assign five-year rotations in the early sample years (i.e., 2008 and 2009). Without this assumption, we lose 11.4 percent of the observations. However, we verify that the results are similar, and none of our inferences changes, when we drop back-filled observations (not tabulated). 
capture (time invariant) unobservable client characteristics and aspects of the client-audit firm match. Throughout the analyses, we assess the statistical significance of the OLS coefficient estimates using robust standard errors clustered by client firm.

\subsection{Proxies for audit quality and audit economics}

Our proxies for audit quality comprise the following measures: (i) absolute accruals, (ii) actual or announced restatements, (iii) opinions about material weaknesses for financials which are later restated, and (iv) inspection findings by the PCAOB or by the audit firms internally. ${ }^{20}$

Our first measure of audit quality is total Absolute Accruals. ${ }^{21}$ Accounting manipulations that are not identified and corrected by the auditor should manifest in accruals. But accruals also reflect clients' reporting choices and their business processes and, hence, are only an indirect measure of audit quality. Despite a number of well-known conceptual weaknesses (e.g., Hribar and Nichols, 2007; Dechow, Ge, and Schrand, 2010), accrual measures are widely used in the audit literature (see, e.g., DeFond and Zhang, 2014). We include them in the analysis, among other things, to benchmark our findings with prior research.

Our next set of audit quality proxies rely on restatements and/or internal control weaknesses. By their very nature, these events are infrequent, but they reflect poor financial reporting and are arguably more closely related to problems with audit quality. We code these events as binary indicators taking on a value of ' 1 ' in case of occurrence. Restated Financials represent annual reports that originally received an unqualified audit opinion, but subsequently had to be restated because the client and/or the auditor identified a material departure from GAAP. We measure the variable in the fiscal year of the restated reports. Announced Restatement code the year in which

${ }^{20}$ For details on the exact definitions and data sources, see Appendix A.

21 Given the conceptual flaws of two-stage discretionary accrual measures, we prefer to use total accruals. This approach avoids econometric issues related to the decomposition of accruals (Chen, Melessa, and Hribar 2017). 
a restatement is subsequently announced. The announcement could take place several years after the material departure from GAAP. Under SOX, management is required to assess the effectiveness of its internal controls over financial reporting, and the auditor must provide an opinion on management's assessment. We first identify instances where the auditor agrees with management's assessment of material control weaknesses (MCW). Such a situation could arise when a client finds and corrects a misstatement in preparing its financials, indicating internal control issues, and the auditor concurs that the client does not have proper controls to systematically "catch" such errors. We then limit the coding of the variable $404 b$ Opinion with $M C W$ to firm-years that are later restated. By only using these firm-years, we eliminate Type 1 errors and focus on observations with (ex post revealed) GAAP departures or misstatements that the auditor (ex ante) flagged as having material control weaknesses.

In addition, we use confidential PCAOB data to identify cases when the specific audit engagement had deficiencies according to the PCAOB or the audit firm's internal inspections. The $P C A O B$ Inspection Finding variable is set to ' 1 ' when, during its inspections, the PCAOB staff finds audit evidence that is insufficient to support an engagement's opinion and mentions this deficiency in the audit firm's inspection report (so-called Part I finding; PCAOB 2004). Such findings are often substantial (e.g., they are often related to restatements as shown in the appendix of Gipper, Leuz, and Maffett, 2017). Audit firms are required to internally monitor engagement quality. To fulfill this requirement, they perform internal inspections of their engagements and report results to the PCAOB (e.g., Bell et al., 2015). We set the variable Audit Firm Inspection Finding to ' 1 ' when there are any findings in internal inspections (e.g., minor findings like the lack of sufficient documentation of audit work or major findings like the failure 
to perform certain audit procedures). Both inspection findings variables are available only for client-years that were subject to the respective inspections.

It is important to note that our audit quality proxies do not uniformly indicate low (or high) audit quality. These nuances in the proxies allow insights into the various hypotheses for audit quality related to partner tenure and rotations (i.e., fresh look, learning, or capture), especially when we combine them with certain points in the partner cycle. For example, an Announced Restatement presumably occurs when the auditor discovers or facilitates the correction of prior misstatements, which indicates strong audits. Thus, this variable is particularly suited to study fresh-look benefits after rotations. ${ }^{22}$ Similarly, a $404 b$ Opinion with $M C W$ variable does not imply low audit quality, considering that the auditor flags the internal controls in a year that is later restated. The converse might indicate an audit failure, for instance, due to partner capture towards the end of the tenure or, alternatively, early on due to unfamiliarity with the client's systems. Restated Financials are typically viewed as indicating low quality audits based on the notion that the auditors failed to catch such misstatements. Similarly, a PCAOB Inspection Finding or an Audit Firm Inspection Finding typically indicate deficiencies and, hence, lower quality audit. Such "low quality events" could lead to early partner rotations. Flagging a client's internal controls as having material weaknesses could lead to dissonances in the relationship, leading to rotations before the five-year limit.

Finally, our proxies related to the economics and the process of audits comprise the following measures: (i) audit and non-audit fees, (ii) audit hours, and (iii) total partner and engagement partner hours. The Audit Fees and Non-Audit Fees paid by client $i$ in year $t$ are publicly available in the proxy statements. They represent the price for the audit services. For the

\footnotetext{
${ }^{22}$ Later in the tenure cycle, an Announced Restatement could indicate experience (i.e., some familiarity of the client
} is necessary to uncover and correct a prior misstatement). 
other variables, we rely on PCAOB data. Audit Hours serve as proxy for audit effort or input. Total Partner Hours and Engagement Partner Hours are of special importance for our study as they measure the input of the partners (as a group) and the lead partner with respect to a specific engagement over the tenure cycle. ${ }^{23}$

\subsection{Sample construction and description}

The PCAOB collects data from all audit firms but only the large auditors are subject to yearly inspections and provide data annually in machine-readable format. Thus, we focus on large, annually inspected audit firms. Table 1 provides an overview of the sample by audit firm (Panel A) and year (Panel B). We include all client-years from the six largest audit firms, for which we have PCAOB data as well as the relevant data for the main control variables from 2008 to 2014. The sample contains a maximum of 17,903 observations from 3,333 individual clients. Compared to the universe in Audit Analytics, our sample covers 67 (78) percent of the Big 6 clients (client-years). We lose a few observations of smaller clients for the Big 6 as input data to compute the control variables are missing. Clients of non-Big 6 auditors tend to be much smaller (i.e., average market value of non-Big 6 clients is $\$ 107$ million compared to our sample mean of $\$ 5,880$ million). Overall, our sample covers about 46 percent of the SEC registrants in the U.S. but 85 percent in terms of aggregate market capitalization.

Panel B of Table 1 provides a breakdown of the sample by years. It also shows the yearly numbers of within-firm partner rotations and audit-firm switches. For partner rotations, we distinguish between five-year rotations and non-mandatory rotations that fall short of the five-

\footnotetext{
23 The way the PCAOB collects partner hours has changed over time. From 2008 to 2011, the variable contains all partner hours including the lead partner, review partner, and other partners (e.g. relationship, IT, tax, etc.; Total Partner Hours). From 2012 onwards, the variable contains only the hours of the engagement partner (Engagement Partner Hours). In Appendix B, we analyze two more variables related to the audit process and economics, namely billing realization (Section B1) and review partner hours (Section B2).
} 
year limit. The somewhat elevated numbers of mandated rotations in 2008 and 2009 likely reflect missing tenure information for the preceding years in combination with our coding choices as well as the phase-in of SOX (see footnote 12). The number of non-mandatory rotations is fairly high, and even outpaces the number of mandatory rotations in 2011 and 2012. This finding is descriptively important and contrasts with anecdotal (and survey) evidence in prior literature. ${ }^{24}$ In contrast, audit firm switches are infrequent, consistent with prior literature (e.g., Minutti-Meza, 2013). We observe only 431 switches, and the numbers are particularly low during the financial crisis. Overall, our sample covers 3,852 audit partner changes.

Table 2 provides descriptive statistics for the main variables used in the regression analyses (Panel A) as well as some additional information by engagement partner (Panel B). For details on the variable definitions and data sources, see Appendix A. The mean (review) partner tenure is 2.7 (2.5) years, consistent with the presence of early rotations. In 17 percent of the clientyears, issuers restated their financials; they announced restatements in 6 percent of the clientyears. 404b opinions with MCW (and subsequent restatements) are rare events, occurring only in 10.2 percent of the restated client-years. About 10 percent of the sample observations are subject to PCAOB inspections and internal audit-firm inspections. Interestingly, both programs yield a similar frequency of findings, with 34 and 26 percent of the inspected engagements, respectively.

The distribution of audit fees and audit hours is highly skewed, reflecting the heterogeneity among audit clients. The median lead partner spends 293 hours on the engagement. This number amounts to 4.5 percent of the total audit hours for the median client. These figures are comparable to prior studies (e.g., O'Keefe, Simunic, and Stein, 1994; Hackenbrack and Hogan,

\footnotetext{
${ }^{24}$ For instance, Litt et al., 2014, p.67, survey 13 offices from Big 4 audit firms and receive responses indicating only one pre-five-year rotation. Laurion et al., 2017, p. 211, had discussions with partners from all Big 4 firms and find "few partner rotations in the U.S. are voluntary." We validate the high frequency of non-mandatory rotations that we observe in our sample using an alternative data source (see Appendix B, Section B3.1).
} 
2005; Bell, Doogar, and Solomon, 2008). The median review partner spends 51 hours per engagement. Taken together, lead partner and review partner hours come close to the median pooled Total Partner Hours (i.e., $293+51 \approx 358$ ). Most engagements fall into the intermediate risk category, as indicated by an interquartile range of zero for the Client Risk Rating.

Panel B provides additional descriptive information on engagement and review partners for Big 6 audit firms. On average, a partner acts as an engagement partner for two public issuers and five non-issuers (e.g., not-for-profit entities or private entities). The numbers are similar but slightly smaller for review partners. The average engagement partner manages more than 23,000 staff hours per year and spends about 60 percent of her time on billable client work. The average engagement partner has 10 years of experience on the job.

\section{Main analyses of audit partner tenure and rotation}

\subsection{Results for audit quality}

We begin our audit quality analyses using Absolute Accruals as the dependent variable. In column (1) of Table 3, we report coefficient estimates and (in parentheses) standard errors from estimating Eq. (1). In addition to the variable of interest, we report the coefficient on Client Risk Rating. As auditors likely respond with more effort to higher perceived audit risk, the sign of the relation between the rating and accruals is ex ante not obvious. We further include (but do not report) an extensive set of client-specific controls plus fixed effects. Specifically, we include firm size, financial leverage, contemporaneous and lagged return on assets, an indicator for loss firms, operating cash flow, the book-to-market ratio, and Altman's Z-score as default risk proxy. We also include controls for a firm's operating activities and business process such as sales growth, cash flow volatility, indicators for firms undergoing restructuring or being involved in 
M\&A transactions and the Jones (1991) model regressors (i.e., the inverse of total assets, sales growth, and PP\&E over total assets) together with the lagged turnover of accounts receivables and payables (Dechow and Dichev, 2002; Chen et al., 2017). We include fixed effects for clients, years, audit firm tenure, and the client firm's industry decile rank in terms of its return on assets. Appendix A contains variable definitions; in Appendix B, we tabulate the full models.

The estimated coefficient on Partner Tenure is insignificant and close to zero in magnitude (about two basis points of total assets per tenure year). Based on the magnitude of the standard errors, we could detect accrual effects as small as 7 basis points of total assets per year of partner tenure, if they were present. Thus, we conclude that there is no association between partner tenure and absolute accruals.

Columns (2) to (6) of Table 3 contain results for the other audit quality proxies. The specifications are the same except that we include absolute accruals as a control and drop the Jones model regressors, receivables and payables turnover and the industry-performance decile fixed effects, which are specific to the accruals model. We report $t$-statistics (in parentheses) instead of standard errors in these columns. In line with Laurion et al. (2017), we find a significantly negative coefficient on Partner Tenure for announced restatements, which can be viewed as evidence of "fresh-look" benefits after rotations. Yet, for the year of the restated financials, the 404b Opinion with subsequent restatements and the inspection findings either by the PCAOB or the audit firm, the Partner Tenure coefficient is small and insignificant.

In sum, the results show that, for the average engagement in our sample, proxies of audit quality are unrelated to partner tenure (except for the announcement of restated financials). ${ }^{25}$

25 To compare our internal inspection findings to those in Bell et al. (2015), we re-estimate our main specification with an indicator for major findings only (which occurs in our audit firm inspection sample at a rate of 8.8 percent, comparable to the 7.5 percent in Bell et al. (2015). With this modification, Partner Tenure has a 
Importantly, the coefficients on the audit quality variables are all small. Thus, our "non-result" does not seem to be a matter of power. Moreover, we examine many different audit quality proxies, and so it is also unlikely to reflect measurement error. ${ }^{26}$ The lack of tenure effects in audit quality is inconsistent with many prior studies using U.S. data (e.g., Manry et al., 2008; Litt et al., 2014; Fitzgerald et al., 2015) or international samples (e.g., Chen et al., 2008; Lennox et al. 2014). One reason might be that we use a tight model specification, including client, year, and audit firm tenure fixed effects, which controls for many confounds. Another plausible interpretation is that, in the U.S. with its robust reporting and audit environment, the rotation mandate is sufficient to prevent major declines in audit quality over the partner's five-year term.

\subsection{Results for audit fees}

Next, we examine several audit-process related proxies to better understand the economics of partner tenure and rotation. We begin with (log transformed) Audit Fees as the dependent variable. This variable has been used as proxy for audit pricing in the literature, reflecting many factors such as client size, risk, complexity, or financial statement verification (e.g., Simunic, 1980; Hay et al., 2006; Kealey, Lee, and Stein, 2007; Ball et al., 2012; Bell et al., 2015). Table 4, Panel A, reports coefficients and (in parentheses) $t$-statistics clustered by client from estimating Eq. (1). In some specifications, we control for client risk and the effort the auditor exerts in terms of (log transformed) Audit Hours. We include the same basic set of controls (i.e., everything from firm size to cash-flow volatility) and fixed effects as in the audit quality models. In addition we control for total absolute accruals, current assets, the number of days between the fiscal-year

coefficient of 0.008 with a $t$-statistic of 1.68 (p-value of 0.093 ). This finding could be viewed as evidence for audit quality declines over the tenure cycle, but we are hesitant to do so in light of our other results.

${ }^{26}$ In additional analyses (not tabulated), we estimate the tenure relation using going concern opinions (across the entire sample and conditional on negative cash flows), the M-Score (Beneish, 1999) and the F-Score (Dechow, Ge, Larson, and Sloan, 2011). In all cases, our inferences for partner tenure do not change. 
end and the signing of the audit opinion, the number of business segments, and foreign sales (for a tabulation of the full model see Appendix B). The explanatory power of the models exceeds 97 percent (or, without client fixed effects, ranges between 77 and 91 percent; not tabulated).

The coefficient on Partner Tenure in column (1) is positive and significant at the fivepercent level, suggesting that audit fees increase over the five-year tenure of the engagement partner. Next, we add Client Risk Rating and Audit Hours to the set of controls. Perhaps surprisingly, the coefficient on client risk is not significant (column 2), but this could reflect our extensive controls, which among other things likely also capture client risk. When we replace the continuous Client Risk Rating variable with an indicator for particularly risky clients (i.e., those with a risk rating of 4 and 5) in column (3), the coefficient on the risk variable becomes positive and significant, suggesting that high-risk clients are charged higher fees. Because audit fees and hours are simultaneously determined, it is not surprising that when we add Audit Hours to the model, the two variables are highly correlated. At the same time, the identification of the Partner Tenure effects becomes sharper in that the coefficient gets larger and more significant.

In column (4), we map out the fee associations for each tenure year by estimating Eq. (2). In tenure year 1, we observe a significant drop in audit fees, followed by a systematic increase over the tenure cycle. This fee pattern is similar in spirit to the "low-balling" results around audit-firm switches (e.g., Hay et al., 2006), but has not been shown for partner rotation or the partner tenure cycle. It suggests that clients can mount larger fee pressures around partner rotation, perhaps threatening more credibly to switch audit firms. Moreover, the incoming partner may find it harder to push for fee increases. Finally, we find an insignificant association between partner tenure and Non-Audit Fees (column 5), as one would expect if these activities are separated from 
the audit services within the audit firm. However, we note that the point estimate is comparable to the one for Audit Fees and, hence, the result should be interpreted cautiously.

If the above indicated fee pressures exist around rotations, they should be more prevalent in competitive environments. To test this conjecture and corroborate our interpretation of the fee pattern, we estimate the audit fee model separately for local audit markets with high and low competition. We create a binary indicator, High Competition, set equal to ' 1 ' in year $t$ if the competition among the auditors in the city of the signing partner's office is above the median. We measure competition based on a Herfindahl index computed using either local audit fees or audit hours. We introduce this indicator as a main effect and an interaction term with Partner Tenure in Eq. (1) and report results in Panel B of Table 4. Columns (1) and (4) show that audit fees start out lower in highly competitive markets. The coefficient on High Competition is negative and-when measuring competition based on audit hours-ignificant. The interaction term between High Competition and Partner Tenure is positive and significant, suggesting that the lower fees in a competitive environment are at least partly recovered in the subsequent years.

Next, we analyze the year-by-year pattern in audit fees by separately estimating Eq. (2) for local markets with high and low competition. We tabulate only the coefficients for Tenure Year 1 and Tenure Year 5 as they are the most relevant years. The results show that rotation-related fee effects seem to occur only in highly competitive markets. In both columns (2) and (5), the coefficient on the initial tenure year is significantly negative and more than twice the magnitude than the same coefficients in columns (3) and (6) with low competition. In additional tests (not tabulated), we re-run the competition analyses with the audit quality proxies or Audit Hours as the dependent variables. We do not find differences between high and low competition markets 
for these outcomes, which further corroborates that the fee effects reflect competition, rather than client differences across local markets.

\subsection{Results for audit hours and partner hours}

Table 5, Panel A, reports results on audit and partner hours. The models include Client Risk Rating and the same client-specific controls and fixed effects as the audit fee model (for a tabulation of the full models see Appendix B). In column (1), we examine total Audit Hours and find a steady decrease over the tenure cycle. This decrease follows a substantial jump in audit hours in the initial two years after rotation, as the results mapping out the individual tenure years in column (4) indicate. The increase in total hours in the initial years suggests that rotations are costly to audit firms. The subsequent decline likely reflects learning and/or efforts to make engagements more profitable.

In column (2), we analyze Total Partner Hours. This variable includes all partners on the engagement and is available for the years 2008 to 2011. The coefficient on tenure is negative but not significant. The year-by-year mapping in column (5) suggests a U-shaped form with substantially more total partner hours in the first and last year of the cycle. Next, in column (3), we analyze Engagement Partner Hours, which are closer to the construct we have in mind but are only available for the years 2012 to 2014. The coefficient on Partner Tenure becomes highly significant. As the mapping in column (6) indicates, the lead partner's effort increases substantially in the first year after the transition, but then drops significantly in years four and even more so in year five on the assignment. Combining the results in columns (5) and (6), the pattern could reflect "shadowing" by the new incoming partner, which would manifest in less effort exerted by the lead partner but more Total Partner Hours in year five. Overall, the results in Panel A suggest that when a new partner begins a five-year cycle, she needs to spend more 
time, for instance, familiarizing herself with the audit procedures in place. Over time, she can reduce her effort, and towards the end of the cycle a shadowing partner may in some cases take part of the workload. ${ }^{27}$

Considering our evidence that partner rotations are disruptive to the process and economics of the audit, we examine other dials that audit firms can turn to reduce these effects. In particular, we study the arrival of other audit team members relative to the lead partner rotation. Exploiting data on review partner and senior manager switches, we create a binary indicator, New Team Member, set equal to ' 1 ' in years when a new review partner and/or senior manager arrives. ${ }^{28} \mathrm{We}$ use this indicator twofold: (i) as a dependent variable in estimating Eq. (2), and (ii) as an additional main effect and interaction term in estimating Eq. (1) for total Audit Hours. We report the results from these specifications in Panel B of Table 5. Columns (1) focus on explaining the arrival of a new review partner, senior manager, or either one of the two. We find that review partners are more likely to rotate when the lead partner is in years one and five. New senior managers are more likely to arrive together with a lead partner. This rotation pattern might be counterintuitive as senior managers could provide continuity and minimize disruptions around engagement partner rotations. However, lead partners and senior managers could also form "teams." Pairing the engagement partner and a senior manager and rotating them at the same time could provide incremental "fresh-look" benefits (see also Table 7). When we examine the interaction between partner tenure and new team members with respect to Audit Hours in columns (2), we find that bringing in new senior managers is associated with higher audit hours, suggesting that these rotations are disruptive. The effects are insignificant for review partners, which seems sensible given they spend less time on the engagement. We find no interactive

${ }^{27}$ We corroborate this interpretation and provide more evidence on "shadowing" in Table 6.

${ }^{28}$ For senior managers, we set the indicator to ' 1 ' if any of them changes. About $79 \%$ of client-year observations have only one senior manager. When we limit the coding to this subsample, our inferences do not change. 
effect with lead partner tenure. Because these audit hour effects could plausibly be explained by lead partner rotation, we estimate the interaction effect separately for the first tenure year of the lead partner and the other years (not tabulated). Doing so, we still find incremental hour effects with a new team member during non-first years of the partner.

In sum, our analyses of the economic and audit-process variables suggest significant partner tenure effects over the cycle and that partner rotations are disruptive and have economic consequences at the engagement level. Audit firms appear to systematically manage these consequences, including the rotations of other audit team members. Together with the earlier audit quality results, our findings suggest that the disruptions are managed by the audit firms such that they do not lead to systematic quality issues around mandatory rotations.

\section{Cross-sectional analyses of audit partner tenure and rotation}

Up to this point, our analysis provides results for the average engagement of Big- 6 audit firms in the U.S. In this section, we consider a number of cross-sectional splits and special settings, in which audit quality concerns and, therefore, fresh-look benefits as well as learning effects and disruptions may be more pronounced. We also examine non-mandatory (or early) partner rotations to see if such rotations are related to accounting or audit failures. The latter is not obvious considering that partner names are not disclosed during our sample period.

\subsection{Partner experience and client size}

We start by analyzing cross-sectional splits related to partner experience and client size (or complexity). Specifically, we estimate Eq. (2) separately for client-years from newer versus more experienced lead partners or big versus small clients. Table 6 reports the results for these 
partitions using Partner Hours as the dependent variable. ${ }^{29}$ We tabulate only the main variables of interest, but the model contains the full set of controls and fixed effects.

We proxy for a lead partner's experience by counting the years since she was granted partnership at the firm and distinguish between newer and more experienced partners by splitting the sample at the median. Using Engagement Partner Hours, we find that the coefficient on Tenure Year 1 is positive and significant in the subset of newer partners only. At the same time, the coefficients on Tenure Years 4 and 5 are significantly negative for both subsets, but larger in magnitude for newer partners. Thus, less experienced partners spend relatively more time in the initial year of a rotation cycle, but also see larger declines in hours in the later years, suggesting that they have a steeper learning curve or exhibit more pronounced learning effects.

Client size and client complexity are likely important considerations when managing partner rotations. We use total assets as a proxy for complexity and split the sample by the median. We expect that, for large and complex clients, new partner assignments are made far in advance of mandatory rotation to smooth the transition and to give the new partner time to learn about the new client. Anecdotally, the process begins up to two years prior to the incoming partner's first year. As we have data (albeit for different, non-overlapping periods) on Total Partner Hours and Engagement Partner Hours, we can examine the transition behavior by comparing these two variables over the cycle. Overall, the evidence is consistent with the notion that large clients have incoming partners "shadow" outgoing partners. We find that total partner hours increase significantly in year five (column 3), but the lead partner's hours decrease substantially over the last two years of the cycle (column 5), consistent with shadowing allowing the outgoing partner

${ }^{29}$ We also estimate these partitions for Audit Hours, Audit Fees, and the audit quality proxies. Because these alternative dependent variables yield results very similar to the average results and do not allow for new insights, we do not report them in the table. 
to spend less time on the client. This pattern is already present in Panel A of Table 5, but showing that the increase in total partner hours stems primarily from large clients corroborates our interpretation. Furthermore, large clients exhibit smaller post-rotation increases in the workload of the lead partner, as shown by the insignificant coefficient on Tenure Year 1 in column (5). This result makes sense if the incoming partner already had time to accustom herself with the client. For smaller clients, we find no evidence of shadowing and, hence, the incoming partner needs to spend more hours in the initial year.

\subsection{Audit firm switches and audit team rotations}

We next examine two settings in which the "fresh look" benefits could be much stronger, namely the switch of the auditor and the rotation of multiple audit team members. We create an indicator variable marking the entire initial partner cycle (i.e., year 1 up to year 5) under either a new audit firm (Audit Firm Switch Cycle) or a new audit team, defined as the arrival of a new engagement partner together with a new review partner or senior manager (Audit Team Rotation Cycle). We then introduce this indicator as a main effect and interaction term with Partner Tenure in Eq. (1). Table 7 reports the results from estimating this specification for various audit economics and audit quality variables around switches of the auditor (Panel A) and around audit team rotations (Panel B). We tabulate only the coefficients of interest, but the model contains the full set of controls and fixed effects.

Switches of the audit firm are rare events, only occurring in 2.3 percent of client-years. They involve a substantial investment on the part of the auditor and clients likely exert pressure on prices, involving bids from multiple firms (DeAngelo, 1981). Consistent with these arguments, we find that audit fees are substantially discounted and audit hours higher in the first cycle under the new auditor (in line with Bell et al., 2015). The coding of Audit Firm Switch Cycle implies 
that this result holds not only compared to the previous audit firm but also relative to regular (or later) partner rotations with the new firm. Interestingly, the new auditor can make up for most of the fee discounts and reduce the extra effort over the initial rotation cycle. The interaction term between Audit Firm Switch Cycle and Partner Tenure is positive and negative for audit fees and audit hours, respectively, indicating a steeper fee increase and quicker audit hours reduction over the initial tenure cycle. The lead partner's effort does not seem affected by the audit firm switch, although the coefficients behave similarly to total audit hours, suggesting that low power might drive the insignificance.

In terms of audit quality, we find a higher likelihood that the new audit firm issues a $404 \mathrm{~b}$ opinion with material control weaknesses and that the PCAOB issues a Part I finding. The Audit Firm Switch Cycle variable is positive and significant in both of these models (columns 6 and 7). The $404 \mathrm{~b}$ opinion result suggests that new audit firms are more likely (or willing) to flag clients that have material internal control weaknesses, consistent with fresh-look benefits. The PCAOB inspection result indicates that new clients might require extensive learning and new systems, which in turn makes it more likely that, early on, PCAOB inspections uncover audit deficiencies. We do not find significant results for the other audit quality proxies (except for announced restatements, which are significantly related to Partner Tenure as in Table 3).

In Panel B, we report results for audit team rotations. The audit economics results are similar to what we observe for audit firm switches, but—as one would expect-less pronounced. The magnitudes of the coefficients on Audit Team Rotation Cycle and its interactions are much smaller than those in Panel A, and the fee decline during the initial cycle is not significant. For audit quality, we find a higher likelihood that the client restates its financials and announces a restatement during the initial cycle of the new audit team. At the same time, Partner Tenure is 
not significant in the Announced Restatement model (column 5) anymore, indicating that the "fresh look" effects we show in Table 3 for this variable are primarily driven by the arrival of new teams. In line with this argument, new audit teams are more likely to issue an opinion on material control weaknesses in the initial cycle (column 6). However, the fact that we also observe a higher likelihood of actual restatements (which are detected and announced at a later point in time), suggests that "fresh look" could come at a cost in that new teams are less familiar with the client and may overlook accounting misstatements. The (relatively large) point estimates for the initial rotation cycle when examining PCAOB and internal inspection findings are consistent with this latter concern (but we lack power to reject the null). In Section B3.3 of Appendix B, we provide further descriptive evidence on audit firms' team rotation practices.

\subsection{Non-mandatory rotations of engagement partners}

In the last set of analyses, we consider within-firm engagement partner switches that occur before the end of the five-year term limit. There are several potential reasons for such nonmandatory rotations. First, a client could pressure the audit firm to rotate the partner because of dissonances in the relationship or disagreements over certain accounting treatments. Particularly, early terminations could take place when the lead partner attempts to force the client to change poor or misleading accounting practices. Examples are Arthur Andersen's removal of Carl Bass from Enron (Greising, 2002) or KPMG's removal of Ronald Safran from Xerox (Andrejczak, 2003). In such cases, the year before the non-mandatory rotation likely exhibits low financialreporting and audit quality. Second, the client could request an early rotation after a restatement or a PCAOB finding. Even without such events, the client could identify the need for a more experienced or technically competent audit partner and request a rotation. Third, the audit firm could determine that the lead partner's audit is low quality, for instance, over the course of the 
internal inspections, and rotate without explicit request from the client. In the latter two cases, we expect to observe lower audit quality prior to the rotation and higher quality thereafter.

There are of course many other reasons why a lead partner rotates early. The partner may depart for personal reasons (e.g., retirement, health issues, or relocation). The audit firm could reallocate partners because of promotions, long-term career planning, or the need for a partner's special skills at another client. Early rotations for personal reasons or planning considerations by the audit firm are less likely to reflect systematic audit quality issues and, in this sense, are more exogenous (see also, Chen and Wang, 2016). Thus, we expect fewer, if any, systematic audit quality changes for these explainable non-mandatory rotations (except possibly for the year after the rotation if they were unexpected).

We analyze the effects around non-mandatory rotations by including two additional variables in Eq. (2), namely an indicator for the last year of the outgoing partner who leaves before completing a five-year cycle (Year before Non-Mandatory Rotation) and an indicator for the first year of the incoming partner (Year after Non-Mandatory Rotation). These two variables measure the incremental effects from non-mandatory rotations beyond what normally occurs over the five-year tenure cycle. ${ }^{30}$ We also include an indicator that marks the year before a client switches auditors (Year before Audit Firm Switch). This variable controls for potentially confounding effects of incomplete five-year terms due to a change of audit firm and limits the non-mandatory rotation effects to occur within existing client relationships.

Table 8, Panel A, reports results for the main variables of interest from estimating this specification for various audit economics and audit quality variables. We find no incremental

\footnotetext{
${ }^{30}$ We check and confirm that including the two non-mandatory indicators described above do not materially alter the results that we have reported up this point. Put differently, the results in the earlier sections are for mandatory rotations and not driven by non-mandatory rotations.
} 
results for audit fees around non-mandatory rotations. ${ }^{31}$ Total audit hours are elevated after a non-mandatory rotation (but not before; column 2), pointing to extra effort after unexpected or early switches. Engagement partner hours are lower prior to a non-mandatory switch, plausibly reflecting that the removal of the partner from the engagement or transition management. In terms of audit quality, we find that, in the last year before the lead partner leaves prematurely, the client is more likely to restate its financials, announce a restatement or to have a qualified $404 \mathrm{~b}$ opinion. We also observe that the likelihood of a PCAOB inspection finding is elevated, although the coefficient is not statistically significant (column 7).$^{32}$ Internal inspection findings are not significantly associated with early rotations and the coefficient is negative. We do not find any audit quality effects in the first year of the incoming partner after an early rotation. Finally, the likelihood of an audit firm switch is higher after "quality" events, which could also reflect a relationship dissonance after a restatement announcement or the issuance of a qualified 404b opinion.

As noted above, early rotations can take place for different reasons. Thus, we next examine the effects for explainable (or planned) non-mandatory rotations and all the others (unexplained) non-mandatory rotations. To do so, we split the Year before Non-Mandatory Rotation variable into two components, one for transitions following a common-sense pattern in the data likely representing such motives as retirements, promotions, or dislocations (indicated by the subscript expl) and the rest (unexpl). For variable details see Section B3.2 of Appendix B. We report result for this distinction in Table 8, Panel B.

31 Non-mandatory rotations occur with stable frequency over the first four years of the tenure cycle. In our sample, we count 346, 380, 340, and 401 switches in tenure years one, two, three, and four, respectively.

32 The Year before Non-Mandatory Rotation coefficient for PCAOB inspection findings is larger than for any of the significant audit quality models, suggesting that lack of power is the reason for the insignificance. Our analyses in Panel B of Table 8 confirm this conjecture. This interpretation is in contrast to how Aobdia and Petacchi (2017) interpret the (insignificant) effect of PCAOB inspection findings on future lead partner rotations. However, we read their results (and coefficients) as consistent with ours, reflecting lack of power (rather than transparency). 
We observe more total audit hours prior to explainable but not for unexplained early rotations (column 2). The lead partner spends significantly fewer hours on the engagement in the year before explainable non-mandatory rotations. The magnitude of the coefficient $(-0.116)$ is similar to the reduction in lead partner hours in year five of the regular tenure cycle (i.e., -0.167 in Panel A of Table 5), reflecting orderly transition management (or the reasons for the early transition). For audit quality, we find that unexplained non-mandatory rotations are significantly associated with all but internal inspection findings. Clients are more likely to restate, announce a restatement, or have a 404b opinion with a material control weakness or auditors have a PCAOB inspection finding. None of the audit quality proxies significantly loads in the year before an explainable transition of the partner. These differential findings are intuitive and lend credibility to our partitioning variable. More importantly, the results for unexplained early rotations suggest that low audit quality or financial reporting quality have (career) consequences for partners.

Arguably, the "cleanest" audit quality assessments come from PCAOB inspections as they are specifically evaluating, at the engagement level, whether the audit exhibits any deficiencies. In Table 8, Panel C, we focus on various PCAOB inspection outcomes. In column (1), we repeat the results for PCAOB inspection findings, which are published in the audit firm's public report. Next, we show that inspection findings contributing to an audit firm's Part II deficiencies (which are initially not made public and pertain to the audit firm's overall quality control system) also display elevated frequencies in the year before unexplained early rotations. ${ }^{33}$ In column (3), we combine the Part I and II findings and use the (log transformed) count as the dependent variable. The results indicate that a $1 \%$ increase in the number of PCAOB findings is associated with a

\footnotetext{
33 The coefficient is not significant at conventional levels ( $p$-value of 0.225 ). However, it is substantially different from the corresponding coefficient for explainable non-mandatory rotations (one-sided $t$-tests). Due to the pervasive nature of quality control problems, any single client audit cannot independently give rise to a Part II finding. Instead, individual findings contribute to an audit firm's quality control deficiencies.
} 
$21 \%$ increase in the likelihood of an unexplained non-mandatory rotation. No such effect is present for planned transitions. Finally, we distinguish between more and less severe inspection findings. ${ }^{34}$ Consistent with our earlier interpretation that low audit quality plays into early partner rotations, we find a significantly positive association for the incidence of severe inspection findings before unexplained early rotations (but not for less severe findings). The evidence suggests that PCAOB inspections that uncover low audit quality have (rotation) consequences for engagement partners.

\section{Conclusion}

This paper provides the first partner-tenure and rotation analysis for a large cross-section of U.S. publicly-listed audit clients over an extended period. We analyze the effects on audit quality over the mandatory five-year partner tenure cycle as well as other economic tradeoffs related to partner tenure and rotation. We find no evidence for audit quality declines over the five-year tenure cycle and, consistent with that, little support for significant fresh-look benefits after partner rotations. Thus, for the average engagement of large U.S. audit firms, mandatory rotation appears to be short enough and/or the U.S. audit environment robust enough that we cannot find major declines in audit quality or systematic evidence of partner capture over the tenure cycle.

Nevertheless, partner rotations have significant economic consequences. We show that there are fee pressures around partner rotations but also that, in subsequent years, audit firms can make up for these fee pressures. The systematic fee increases over the partner cycle are more pronounced when the local audit market is more competitive. We also document an increase in

\footnotetext{
34 The PCAOB does not distinguish inspection findings by severity; the publicly observable output of the inspection work is binary. Either the audit firm failed to perform sufficient audit work to support an opinion and, hence, has a Part I finding or not. We create this classification marking findings as severe when both the financial statement and the internal controls opinions are not supported or the PCAOB discovers a likely departure from GAAP.
} 
total audit hours and partner hours shortly after rotations, followed by a decline over the tenure cycle, however, without compromising audit quality. We find that engagement partner, review partner and senior manager rotations are disruptive in that they are associated with audit hour increases when the team member is new. The patterns in audit hours over the partner cycle differ by partner experience and client size. The partner hour results are consistent with learning and "shadowing" for larger clients. Furthermore, we provide evidence of similar audit hour patterns over the tenure cycle for review partners.

Generally speaking, the aforementioned findings are consistent with efforts by the audit firms to minimize disruptions and audit failures around mandatory rotations. When we analyze special circumstances, such as audit firm switches and audit team rotations, we find that they are more disruptive than mandatory rotations, and more likely to exhibit audit quality effects, consistent with significant learnings effects for new audit firms or new audit teams early on.

We also examine non-mandatory, early partner rotations. Our study shows that rotations before the five-year limit are more common than previously thought and that they are associated with audit quality issues in the year before the off-cycle rotation. We differentiate between rotations that are explainable by retirements, promotions, office switches, and temporary leaves, and the remainder. We show that unexplained rotations are more likely after an issuer restates its financials audited by the respective partner, a restatement is announced and, in particular, after a PCAOB inspection finding, even though such findings are not disclosed at the engagement level and, hence, less visible than restatements. To corroborate the latter results, we demonstrate that unexplained, non-mandatory rotations are particularly pronounced for PCAOB inspections with more severe findings. Overall, this evidence suggests that low-quality audits, as evidenced by restatements or PCAOB findings, give rise to early engagement partner rotations and in this 
sense low-quality audits have (career) consequences for partners. The fact that we do not find similar quality effects before a more easily explainable or planned non-mandatory rotation lends further credence to this interpretation. Interestingly, we do not find unexplained, non-mandatory rotations are associated with audit firms' internal inspection findings.

Our analysis provides a wealth of novel descriptive evidence for U.S. audits. To highlight a few additional examples: (i) Audit firms charge more for high risk clients and spend more audit hours on these engagements; (ii) new review partners and new senior managers join an engagement more frequently when the lead partner is new as well; (iii) lead partners manage very few SEC audits concurrently, which is in contrast to international settings such as China or Taiwan. Finally, (iv) we show that lead partners often manage several non-SEC audits or may shadow other partners. As these engagements are not observable (even with partner name disclosures), "gap" years in public data for a particular partner should be interpreted cautiously. The evidence in our study serves as an important baseline for future research on the disclosure of engagement partner names, which started in 2017.

In closing, some caveats are in order. First, our analysis relies on associations and does not attempt to provide causal effects. Audit firms purposefully assign lead and review partners to particular engagements, which creates selection and matching issues that need to be addressed before causal inferences can be drawn. Second, our finding that there are no major declines in audit quality over the average partner cycle needs to be interpreted carefully. While it provides an important baseline for a controversial policy issue, it does not imply that a five-year cycle is optimal or that mandatory rotations are justified. It is possible that a longer rotation term would yield similar results, yet be less costly. Thus, the relation between partner tenure and audit quality beyond the five-year period remains an open question for the U.S. audit environment. 


\section{References}

American Institute of Certified Public Accountants (AICPA), 1978. Division for CPA Firms SEC Practice Section: Peer Review Manual. New York, NY: AICPA.

Andrejczak, M., 2003. "KPMG Charged Over Xerox Audit." CBS MarketWatch (January 29, 2003). Available at http://www.marketwatch.com.com/story/kpmg-charged-over-xeroxaudit/print.

Aobdia, D. and Petacchi, R., 2017. Consequences of Low-Quality Audits for Engagement Partners. Working Paper. Northwestern University and Georgetown University.

Azizkhani, M., Monroe, G.S., Shailer, G., 2013. Audit Partner Tenure and Cost of Equity Capital. Auditing: A Journal of Practice \& Theory 32(1), 183-202.

Ball, R., Jayaraman, S., Shivakumar, L., 2012. Audited Financial Reporting and Voluntary Disclosure as Complements: A Test of the Confirmation Hypothesis. Journal of Accounting and Economics 53(1-2), 136-166.

Bamber, E.M., Iyer, V.M., 2007. Auditors' Identification with Their Clients and Its Effect on Auditors' Objectivity. Auditing: A Journal of Practice \& Theory 26(2), 1-24.

Beck, P.J., Frecka, T.J., Solomon, I., 1988. Model of the Market for MAS and Audit Services: Knowledge Spillovers and Auditor-Auditee Bonding. Journal of Accounting Literature 7(1), 50-64.

Bedard, J.C., Johnstone, K.M., 2010. Audit Partner Tenure and Audit Planning and Pricing. Auditing: A Journal of Practice \& Theory 29(2), 45-70.

Bell, T.B., Causholli, M., Knechel, W.R., 2015. Audit Firm Tenure, Non-Audit Services, and Internal Assessments of Audit Quality. Journal of Accounting Research 53(3), 461-509.

Bell, T.B., Doogar, R., Solomon, I., 2008. Audit Labor Usage and Fees under Business Risk Auditing. Journal of Accounting Research 46(4), 729-760.

Beneish, M.D., 1999. The Detection of Earnings Manipulation. Financial Analysts Journal 55(5), 24-36.

Blouin, J., Grein, B.M., Rountree, B.R., 2007. An Analysis of Forced Auditor Change: The Case of Former Arthur Andersen Clients. The Accounting Review 82(3), 621-650.

Cameran, M., Francis, J.R., Marra, A., Pettinicchio, A., 2014. Are There Adverse Consequences of Mandatory Auditor Rotation? Evidence from the Italian Experience. Auditing: A Journal of Practice \& Theory 34(1), 1-24.

Carey, P., Simnett, R., 2006. Audit Partner Tenure and Audit Quality. The Accounting Review 81(3), 653-676.

Center for Audit Quality (CAQ), 2012. Guide to PCAOB Inspections. Self-published (October 1, 2012). Available at http://thecaq.org/guide-pcaob-inspections.

Chen, C-Y., Lin, C-J., Lin, Y-C., 2008. Audit Partner Tenure, Audit Firm Tenure, and Discretionary Accruals: Does Long Auditor Tenure Impair Earnings Quality? Contemporary Accounting Research 25(2), 415-445.

Chen, T.Y., Wang, H.D., 2016. Auditors with or without Styles? Evidence from Unexpected Auditor Turnovers. Working Paper. Hong Kong University of Science and Technology and National Kaohsiung First University of Science and Technology. 
Chen, W., Hribar, P., Melessa, S., 2017. Coefficient Bias when using Residuals as the Dependent Variable. Working Paper. University of Iowa.

Chi, W. and Huang, H., 2005. Discretionary Accruals, Audit-Firm Tenure and Audit-Partner Tenure: Empirical Evidence from Taiwan. Journal of Contemporary Accounting \& Economics 1(1), 65-92.

Chi, W., Huang, H., Liao, Y., Xie, H., 2009. Mandatory Audit Partner Rotation, Audit Quality, and Market Perception: Evidence from Taiwan. Contemporary Accounting Research 26(2), 359-391.

Copley, P.A., Gaver, J.J., Gaver, K.M., 1995. Simultaneous Estimation of the Supply and Demand of Differentiated Audits: Evidence from the Municipal Audit Market. Journal of Accounting Research 33(1), 137-155.

Daugherty, B.E., Dickins, D., Hatfield, R.C., Higgs, J.L., 2012. An Examination of Partner Perceptions of Partner Rotation: Direct and Indirect Consequences to Audit Quality. Auditing: A Journal of Practice \& Theory 31(1), 97-114.

DeAngelo, L.E., 1981. Auditor Independence, 'Low Balling', and Disclosure Regulation. Journal of Accounting and Economics 3(2), 113-127.

Dechow, P.M. and Dichev, I.D., 2002. The Quality of Accruals and Earnings: The Role of Accrual Estimation Errors. The Accounting Review 77(Supplement), 35-59.

Dechow, P.M., Ge, W., Larson, C.R., Sloan, R.G., 2011. Predicting Material Accounting Misstatements. Contemporary Accounting Research 28(1), 17-82.

Dechow, P., Ge, W., Schrand, C., 2010. Understanding Earnings Quality: A Review of the Proxies, Their Determinants and Their Consequences. Journal of Accounting and Economics 50(2-3), 344-401.

DeFond, M., Zhang, J., 2014. A Review of Archival Auditing Research. Journal of Accounting and Economics 58(2-3), 275-326.

Deloitte \& Touche LLP, 2003. Comment Letter of Deloitte \& Touche LLP on the Commission's Proposed Rule Implementing Sections 201, 202, 203, 204, and 206 of the Sarbanes-Oxley Act of 2002. Available at https://www.sec.gov/rules/proposed/s74902/deloitte1.htm.

Ernst \& Young LLP, 2003. File No. S7-49-02 Proposed Rule: Strengthening the Commission's Requirements Regarding Auditor Independence. Available at https://www.sec.gov/rules/proposed/s74902/ernstyoung1.htm

Fargher, N., Lee, H-Y., Mande, V., 2008. The Effect of Audit Partner Tenure on Client Managers' Accounting Discretion. Managerial Auditing Journal 23(2), 161-186.

Firth, M.A., Rui, O.M., Wu, X., 2012. Rotate Back or Not after Mandatory Audit Partner Rotation? Journal of Accounting and Public Policy 31(4), 356-373.

Fitzgerald, B.C., Omer, T.C., Thompson, A.M., 2018. Audit Partner Tenure and Internal Control Reporting Quality: U.S. Evidence from the Not-for-Profit Sector. Contemporary Accounting Research 35(1), 334-364.

Franzel, 2012. "PCAOB: Protecting Investors and the Public Interest". Harvard Law School Forum on Corporate Governance \& Financial Regulation. Available at https://corpgov.law.harvard.edu/2012/10/03/pcaob-protecting-investors-and-the-publicinterest/. 
Gipper, B., Leuz, C., and Maffett, M., 2017. Public Audit Oversight and Reporting Credibility: Evidence from the PCAOB Inspection Regime. Working Paper. Stanford University and University of Chicago.

Gold, A., Lindscheid, F., Pott, C., Watrin, C., 2012. The Effect of Engagement and Review Partner Tenure and Rotation on Audit Quality: Evidence from Germany. Working Paper. VU University Amsterdam.

Greising, D., 2002. "How Fastidious Andersen Lost Its Way with Enron". Chicago Tribune (May 10, 2002). Available at http://articles.chicagotribune.com/2002-0510/business/0205100295_1_enron-account-andersen-partner-carl-bass.

Hackenbrack, K.E., Hogan, C.E., 2005. Client Retention and Engagement-Level Pricing. Auditing: A Journal of Practice \& Theory 24(1), 7-20.

Hamilton, J., Ruddock, C., Stokes, D., Taylor, S., 2005. Audit Partner Rotation, Earnings Quality and Earnings Conservatism. Working Paper. University of New South Wales.

Hay, D.C., Knechel, W.R., Wong, N., 2006. Audit Fees: A Meta-analysis of the Effect of Supply and Demand Attributes. Contemporary Accounting Research 23(1), 141-191.

Hribar, P., Nichols, D.C., 2007. The Use of Unsigned Earnings Quality Measures in Tests of Earnings Management. Journal of Accounting Research 45(5), 1,017-1,053.

Johnson, V.E., Khurana, I.K., Reynolds, J.K., 2002. Audit-Firm Tenure and the Quality of Financial Reports. Contemporary Accounting Research 19(4), 637-660.

Kealey, B.T., Lee, H.Y., Stein, M.T., 2007. The Association between Audit-Firm Tenure and Audit Fees Paid to Successor Auditors: Evidence from Arthur Andersen. Auditing: A Journal of Practice \& Theory 26(2), 95-116.

KPMG LLP, 2003. File No. S7-49-02 Strengthening the Commission's Requirements Regarding Auditor Independence Release Nos. 33-8154, 34-46934, 35-27610, IC-25838, IA-2088, FR-64. Available at https://www.sec.gov/rules/proposed/s74902/kpmg1.htm.

Knapp, M.C., 1991. Factors that Audit Committee Members Use as Surrogates for Audit Quality. Auditing: A Journal of Practice \& Theory 10(1), 35-52.

Kwon, S.Y., Lim, Y., and Simnett, R., 2014. The Effect of Mandatory Audit Firm Rotation on Audit Quality and Audit Fees: Empirical Evidence from the Korean Audit Market. Auditing: A Journal of Practice \& Theory 33(4), 167-196.

Laurion, H., Lawrence, A., Ryans, J.P., 2017. U.S. Audit Partner Rotations. The Accounting Review 92(3), 209-237.

Lennox, C., Wu, X., 2017. A Review of the Archival Literature on Audit Partners. Accounting Horizons, Forthcoming.

Lennox, C.S., Wu, X., Zhang, T., 2014. Does Mandatory Rotation of Audit Partners Improve Audit Quality? The Accounting Review 89(5), 1,775-1,803.

Litt, B., Sharma, D.S., Simpson, T., Tanyi, P.N., 2014. Audit Partner Rotation and Financial Reporting Quality. Auditing: A Journal of Practice \& Theory 33(3), 59-86.

Manry, D.L., Mock, T.J., Turner, J.L., 2008. Does Increased Audit Partner Tenure Reduce Audit Quality? Journal of Accounting, Auditing, \& Finance 23(4), 553-572.

Minutti-Meza, M., 2013. Does Auditor Industry Specialization Improve Audit Quality? Journal of Accounting Research 51(4), 779-817. 
O’Keefe, T.B., Simunic, D.A., Stein, M.T., 1994. The Production of Audit Services: Evidence from a Major Public Accounting Firm. Journal of Accounting Research 32(2), 241-261.

PCAOB, 2004. "Section 4. Inspections: Rule 4000. General." SEC Release No. 34-49787 \& File No. PCAOB-2003-08 (June 1, 2004).

Pitt, H.L., 2002. "Written Testimony Concerning Accounting and Investor Protection Issues Raised by Enron and Other Public Companies." Before the Committee on Banking, Housing and Urban Affairs United States Senate (March 21, 2002). Available at https://www.sec.gov/news/testimony/032102tshlp.htm.

PricewaterhouseCoopers LLP, 2003. Re: File Number S7-49-02. Available at https://www.sec.gov/rules/proposed/s74902/pricewater2.htm.

Sharma, D.S., Tanyi, P.N., Litt, B.A., 2017. Costs of Mandatory Period Audit Partner Rotation: Evidence from Audit Fees and Audit Timeliness. Auditing: A Journal of Practice \& Theory 36(1), 129-149.

Simunic, D.A., 1980. The Pricing of Audit Services: Theory and Evidence. Journal of Accounting Research 18(1), 161-190.

Turner, L.E., 2003. Re: File No. S7-49-02; Strengthening the Commission's Requirements Regarding Auditor Independence. Available at https://www.sec.gov/rules/proposed/s74902/lturner011303.htm.

US House of Representatives, 2002. Sarbanes-Oxley Act of 2002. Public Law 107-204 [H.R. 3763] Washington, D.C.: Government Printing Office.

Watts, R.L., Zimmerman, J.L., 1983. Agency Problems, Auditing, and the Theory of the Firm: Some Evidence. Journal of Law and Economics 26(3), 613-633.

Zeff, S.A., 2003. How the U.S. Accounting Profession Got Where It Is Today: Part I. Accounting Horizons 17(3), 189-205. 
FIGURE 1

Audit Fees and Audit Hours over Tenure Cycle of Engagement Partner

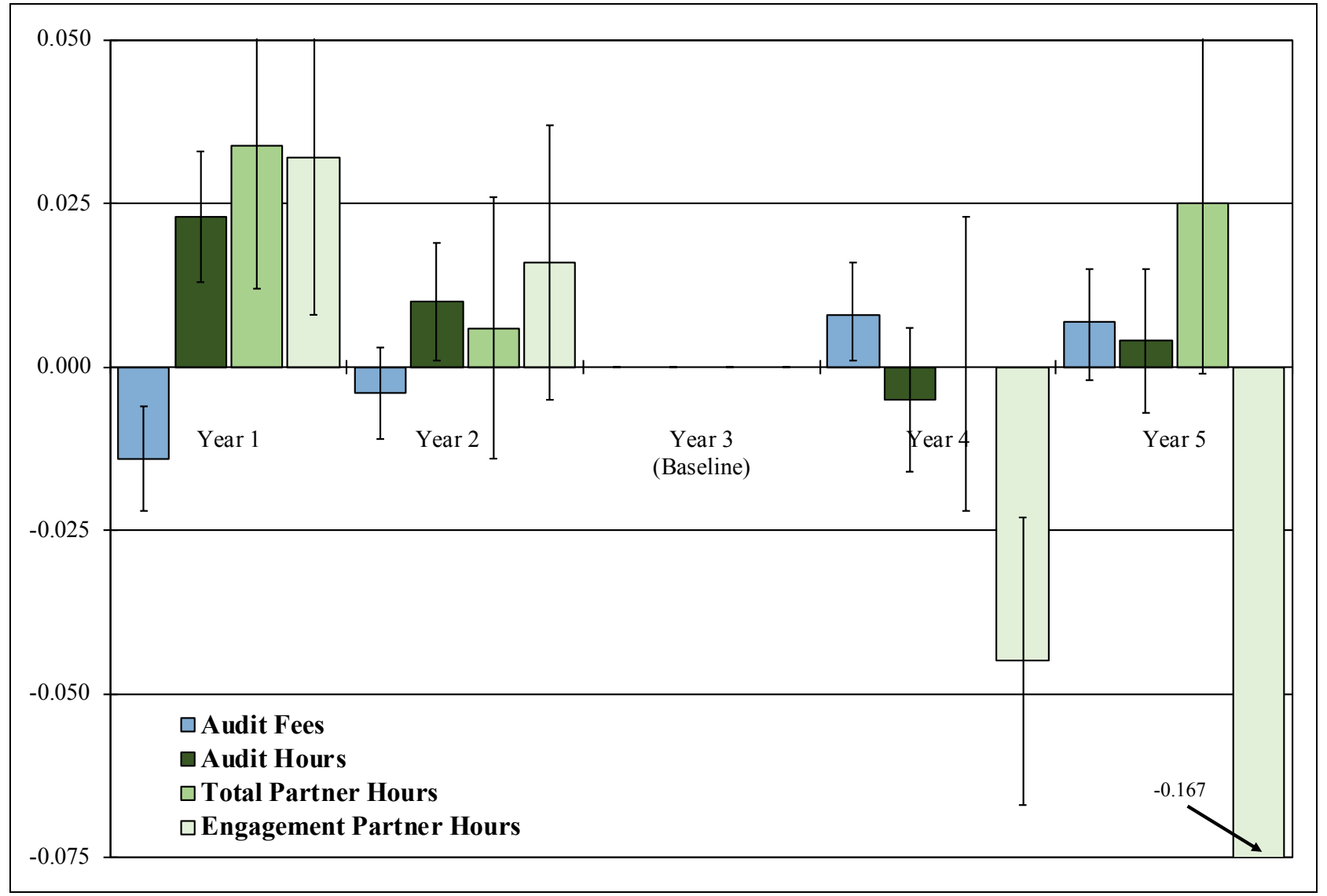

The figure plots ordinary least squares (OLS) coefficient estimates (together with 95 percent confidence intervals) from regressions of Audit Fees and audit effort (measured as Audit Hours, Total Partner Hours, or Engagement Partner Hours) for client $i$ in year $t$ on five separate indicators marking the years 1 to 5 of the tenure cycle of the engagement partner. Year 3 serves as base period and lacks a coefficient estimate. The models include various auditand client-specific control variables plus fixed effects (see notes to Tables 4 and 5 for details). The sample comprises up to 17,903 client-year observations over the 2008-2014 period with PCAOB and control variable data. 
TABLE 1

Sample Composition by Audit Firm and Year

Panel A: Number of Observations and Client Characteristics by Audit Firm

\begin{tabular}{|c|c|c|c|c|c|c|c|c|c|c|c|c|}
\hline & \multicolumn{7}{|c|}{ Full Sample } & \multicolumn{5}{|c|}{ Audit Analytics Universe } \\
\hline & $\mathrm{BDO}$ & Deloitte & EY & GT & KPMG & $\mathrm{PwC}$ & $\begin{array}{l}\text { Total } \\
\text { Big } 6\end{array}$ & $\begin{array}{l}\text { Total } \\
\text { Big } 6\end{array}$ & $\begin{array}{c}\text { Coverage } \\
(\%)\end{array}$ & $\begin{array}{c}\text { Other } \\
\text { Auditors }\end{array}$ & $\begin{array}{l}\text { Total All } \\
\text { Auditors }\end{array}$ & $\begin{array}{c}\text { Coverage } \\
(\%)\end{array}$ \\
\hline Clients & 183 & 651 & 1,017 & 278 & 713 & 739 & 3,333 & 4,947 & $67.4 \%$ & 2,661 & 7,295 & $45.7 \%$ \\
\hline Client-Years & 680 & 3,257 & 5,246 & 1,236 & 3,681 & 3,803 & 17,903 & 23,092 & $77.5 \%$ & 9,434 & 32,526 & $55.0 \%$ \\
\hline Market Value ( $\$$ million) & 608 & 6,516 & 5,966 & 586 & 5,093 & 8,642 & 5,880 & 4,105 & & 107 & 2,946 & \\
\hline Total Fees ( $\$$ thousand) & 854 & 4,075 & 3,060 & 796 & 2,748 & 4,695 & 3,289 & 2,903 & & 249 & 2,138 & \\
\hline
\end{tabular}

Panel B: Number of Observations and Engagement Partner Rotations/Audit Firm Switches by Year

\begin{tabular}{|c|c|c|c|c|c|c|c|c|c|}
\hline \multirow{2}{*}{$\begin{array}{l}\text { Fiscal } \\
\text { Year }\end{array}$} & \multicolumn{4}{|c|}{ Within-Firm Partner Rotations } & \multicolumn{2}{|c|}{ Audit Firm Switches } & \multicolumn{2}{|c|}{ Total Changes } & \multirow{2}{*}{$\begin{array}{c}\text { Total } \\
\text { Observations }\end{array}$} \\
\hline & 5-year & $\%$ & $<5$-year & $\%$ & No. & $\%$ & No. & $\%$ & \\
\hline 2008 & 481 & $20 \%$ & 177 & $7 \%$ & 25 & $1 \%$ & 683 & $28 \%$ & 2,423 \\
\hline 2009 & 401 & $15 \%$ & 235 & $9 \%$ & 20 & $1 \%$ & 656 & $25 \%$ & 2,657 \\
\hline 2010 & 319 & $12 \%$ & 286 & $11 \%$ & 37 & $1 \%$ & 642 & $24 \%$ & 2,685 \\
\hline 2011 & 273 & $10 \%$ & 281 & $11 \%$ & 64 & $2 \%$ & 618 & $24 \%$ & 2,625 \\
\hline 2012 & 259 & $10 \%$ & 288 & $11 \%$ & 93 & $4 \%$ & 640 & $25 \%$ & 2,599 \\
\hline 2013 & 365 & $14 \%$ & 200 & $8 \%$ & 97 & $4 \%$ & 662 & $26 \%$ & 2,566 \\
\hline 2014 & 287 & $12 \%$ & n.a. & n.a. & 95 & $4 \%$ & 382 & $16 \%$ & 2,348 \\
\hline Total & 2,385 & $13 \%$ & 1,467 & $8 \%$ & 431 & $2 \%$ & 4,283 & $24 \%$ & 17,903 \\
\hline
\end{tabular}

Table 1 provides descriptive information on the sample. Panel A gives detail by audit firm and compares the sample totals to the Audit Analytics Universe. The full sample comprises up to 17,903 client-year observations with PCAOB data and available (main) control variables used in the regression analyses. The Big 6 audit firms are BDO USA, Deloitte \& Touche (Deloitte), Ernst \& Young (EY), Grant Thornton (GT), KPMG, and PricewaterhouseCoopers (PwC). The Audit Analytics universe comprises firms with U.S. signing auditors and positive assets, market capitalization, and revenues. We indicate the number of unique clients, client-years, mean client market value, and mean client total fees (audit and non-audit) in the panel. Market value and fee data are from Audit Analytics. Coverage is the percentage of sample firms out of the Audit Analytics universe. Panel B provides detail on within-audit firm rotations and across-audit firm switches, and the number of client-year observations per fiscal year. We code "5-year" rotations as years when the outgoing partner is in her fifth year of tenure (mandatory rotation), and " $<5$-year" rotations as years when the outgoing partner is in her first through fourth year of tenure (non-mandatory rotation). We do not observe the number of "< 5-year" rotations in 2014 because of lack of 2015 data. We identify audit firm switches based on the opinion data in Audit Analytics. The table also indicates the number of total changes (rotations plus switches) and the proportion of changes out of the yearly total observations. 
TABLE 2

Descriptive Statistics

Panel A: Main Variables Used in the Regression Analyses

\begin{tabular}{lrrrrrr}
\hline \hline & $\mathrm{N}$ & Mean & Std. dev. & P25 & Median & P75 \\
\hline Variables of interest: & & & & & & \\
$\quad$ Partner Tenure (years) & 17,903 & 2.671 & 1.397 & 1 & 2 & 4 \\
Review Partner Tenure (years) & 17,751 & 2.522 & 1.360 & 1 & 2 & 4 \\
Audit quality variables: & & & & & & \\
Absolute Accruals (\% of total assets) & 17,903 & 0.080 & 0.090 & 0.026 & 0.054 & 0.100 \\
Restated Financials (indicator) & 17,903 & 0.172 & 0.377 & 0 & 0 & 0 \\
Announced Restatement (indicator) & 17,896 & 0.059 & 0.236 & 0 & 0 & 0 \\
404b Opinion with MCW (indicator) & 2,907 & 0.102 & 0.302 & 0 & 0 & 0 \\
PCAOB Inspection Finding (indicator) & 1,560 & 0.342 & 0.475 & 0 & 0 & 1 \\
Audit Firm Inspection Finding (indicator) & 1,801 & 0.261 & 0.440 & 0 & 0 & 1 \\
Audit economics variables: & & & & & & \\
Audit Fees (\$ thousand) & 17,850 & 2,888 & 4,677 & 734 & 1,350 & 2,892 \\
Non-Audit Fees (\$ thousand) & 17,850 & 401 & 1,056 & 8 & 86 & 329 \\
Audit Hours (hours) & 17,834 & 10,880 & 13,166 & 3,719 & 6,530 & 12,384 \\
Total Partner Hours (hours) & 10,333 & 696 & 1009 & 205 & 358 & 712 \\
Engagement Partner Hours (hours) & 7,493 & 371 & 271 & 183 & 293 & 471 \\
Review Partner Hours (hours) & 17,757 & 67 & 53 & 34 & 51 & 81 \\
Other audit variables: & & & & & & \\
Client Risk Rating (score) & 17,903 & 3.036 & 0.598 & 3 & 3 & 3 \\
New Review Partner (indicator) & 17,751 & 0.304 & 0.460 & 0 & 0 & 1 \\
New Senior Manager (indicator) & 15,484 & 0.439 & 0.496 & 0 & 0 & 1 \\
Audit Firm Switch (indicator) & 17,903 & 0.023 & 0.149 & 0 & 0 & 0 \\
Audit Firm Switch Cycle (indicator) & 17,843 & 0.072 & 0.258 & 0 & 0 & 0 \\
Audit Team Rotation (indicator) & 17,751 & 0.160 & 0.367 & 0 & 0 & 1 \\
Audit Team Rotation Cycle (indicator) & 17,751 & 0.452 & 0.498 & 0 & 0 & 1 \\
\hline \hline
\end{tabular}

Panel B: Information by Audit Engagement Partner and Review Partner

\begin{tabular}{lrrrrrr}
\hline \hline & $\mathrm{N}$ & Mean & Std. dev. & P25 & Median & P75 \\
\hline Engagement Partner Clients (number) & & & & & & \\
$\quad$ observed (per client-year) & 17,249 & 2.0 & 1.0 & 1 & 2 & 2 \\
observed (per partner-year) & 11,153 & 1.5 & 0.8 & 1 & 1 & 2 \\
reported (per partner-year) & 8,552 & 2.1 & 1.4 & 1 & 2 & 3 \\
$\quad$ non-issuer clients (per partner-year) & 8,073 & 5.0 & 6.4 & 1 & 3 & 7 \\
Review Partner Clients (number) & & & & & & \\
reported (per partner-year) & 8,465 & 1.7 & 1.9 & 0 & 1 & 3 \\
non-issuer clients (per partner-year) & 8,380 & 3.1 & 4.2 & 0 & 2 & 4 \\
Audit Hours Managed (hours) & 10,912 & 23,446 & 13,487 & 14,936 & 20,880 & 28,930 \\
Partner Utilization (percentage) & 10,935 & 62.0 & 17.8 & 51.5 & 62.6 & 73.0 \\
Partner Entry Year (calendar year) & 11,150 & 2001 & 6 & 1997 & 2002 & 2005 \\
Partner Experience (years) & 17,246 & 10.2 & 5.9 & 6 & 9 & 14 \\
\hline \hline
\end{tabular}




\section{TABLE 2-Continued}

Table 2 presents descriptive statistics for the main variables used in the regression analyses (Panel A) as well as the audit engagement and review partners in our sample (Panel B). The sample comprises up to 17,903 client-year observations with PCAOB and control variable data. For variable definitions in Panel A see Appendix A. In Panel B, we list the following variables: The number of observed Engagement Partner Clients is a count of issuers with opinions signed by the same audit partner. We provide this statistic for our client-year panel as well as on a partnerby-partner basis. All other variables are taken from what the audit firms report to the PCAOB. Review Partner Clients is a count of clients whose audit engagement the partner reviews. Issuer clients are entities required to file with the U.S. Securities and Exchange Commission (SEC), including subsidiaries or benefit plans that report separately. Nonissuer clients are entities that are not required to file with the SEC (e.g., not-for-profit entities or for-profit entities below SEC reporting thresholds). Audit Hours Managed are total staff hours under the supervision of the audit engagement partner. Partner Utilization measures the time spent on billable client work relative to the available time (i.e., standardized number of hours per week depending on the time of year). For instance, the available time could be 60 (40) hours per week during busy season (other periods) and, thus, a utilization of $60 \%$ indicates that the partner performs 36 (24) hours of billable work on average. Partner Entry Year is the calendar year the employee becomes an audit partner for the firm, either through internal promotion or external hiring. We compute Partner Experience as the current calendar year minus the year the partner was granted partnership at the firm. 
TABLE 3

Engagement Partner Tenure and Audit Quality

\begin{tabular}{|c|c|c|c|c|c|c|}
\hline \multirow[b]{3}{*}{ Dependent Variables: } & (1) & (2) & (3) & (4) & $(5)$ & (6) \\
\hline & \multicolumn{3}{|c|}{ Full Sample } & \multicolumn{3}{|c|}{ Reduced Sample } \\
\hline & $\begin{array}{c}\text { Absolute } \\
\text { Accruals } \\
(\times 100)\end{array}$ & $\begin{array}{c}\text { Restated } \\
\text { Financials }\end{array}$ & $\begin{array}{l}\text { Announced } \\
\text { Restatement }\end{array}$ & $\begin{array}{c}404 b \text { Opinion } \\
\text { with } M C W\end{array}$ & $\begin{array}{c}\text { PCAOB } \\
\text { Inspection } \\
\text { Finding }\end{array}$ & $\begin{array}{c}\text { Audit Firm } \\
\text { Inspection } \\
\text { Finding }\end{array}$ \\
\hline \multicolumn{7}{|l|}{ Audit-specific Variables: } \\
\hline Partner Tenure & $\begin{array}{c}-0.021 \\
(-0.032)\end{array}$ & $\begin{array}{l}-0.001 \\
(-0.81)\end{array}$ & $\begin{array}{l}-0.005 * * * \\
(-3.46)\end{array}$ & $\begin{array}{l}-0.003 \\
(-0.67)\end{array}$ & $\begin{array}{r}0.006 \\
(0.69)\end{array}$ & $\begin{array}{r}0.001 \\
(0.08)\end{array}$ \\
\hline Client Risk Rating & $\begin{array}{l}-0.271 * * \\
(0.109)\end{array}$ & $\begin{array}{l}-0.005 \\
(-0.71)\end{array}$ & $\begin{array}{l}-0.007 \\
(-1.50)\end{array}$ & $\begin{array}{l}0.017 * \\
(1.95)\end{array}$ & $\begin{array}{r}0.016 \\
(0.79)\end{array}$ & $\begin{array}{c}-0.002 \\
(-0.11)\end{array}$ \\
\hline Client-specific Controls & Yes & Yes & Yes & Yes & Yes & Yes \\
\hline $\begin{array}{l}\text { Fixed Effects: } \\
\text { Client (C) or Audit Firm (A) } \\
\text { Year (Y) } \\
\text { Audit Firm Tenure (AT) } \\
\text { Industry-Performance Decile (ID) }\end{array}$ & $\begin{array}{c}\mathrm{C} \\
\mathrm{Y} \\
\mathrm{AT} \\
\mathrm{ID}\end{array}$ & $\begin{array}{c}\mathrm{C} \\
\mathrm{Y} \\
\mathrm{AT}\end{array}$ & $\begin{array}{c}\mathrm{C} \\
\mathrm{Y} \\
\mathrm{AT}\end{array}$ & $\begin{array}{c}\mathrm{A} \times \mathrm{Y} \\
\mathrm{AT}\end{array}$ & $\begin{array}{c}\mathrm{A} \times \mathrm{Y} \\
\mathrm{AT}\end{array}$ & $\begin{array}{c}\mathrm{A} \times \mathrm{Y} \\
\mathrm{AT}\end{array}$ \\
\hline $\begin{array}{l}\text { R-squared } \\
\text { Observations }\end{array}$ & $\begin{array}{c}0.762 \\
16,956\end{array}$ & $\begin{array}{c}0.501 \\
17,660\end{array}$ & $\begin{array}{c}0.221 \\
17,653\end{array}$ & $\begin{array}{l}0.092 \\
2,903\end{array}$ & $\begin{array}{l}0.139 \\
1,560\end{array}$ & $\begin{array}{l}0.225 \\
1,801\end{array}$ \\
\hline
\end{tabular}

The table reports analyses of the relation between engagement partner tenure and audit quality. We measure audit quality for client $i$ in year $t$ using various assessments of a client's reporting process (e.g., whether the auditor issues a $404 \mathrm{~b}$ Opinion with MCW regarding the client's internal controls) and the outcomes of audit-level inspections by the PCAOB or the audit firm. Our variable of interest, Partner Tenure, reflects the number of consecutive years that the audit partner manages the engagement, and ranges from 1 to 5. The audit- and client-specific control variables are: Client Risk Rating, Ln(Market Value), Leverage, Return on Assets in year $t$ and $t$-1, Loss Firm, Cash Flow from Operations, Book-to-Market, Altman Z-Score, Sales Growth, Ln(Cash Flow Volatility), Restructuring Firm, and M\&A Firm. For column 1, we include the Jones (1991) model regressors (i.e., the inverse of Total Assets, Sales Growth, and PP\&E over total assets) and Receivables Turnover and Payables Turnover in year $t$-1. For columns 2-6, we include Absolute Accruals as additional control. Ln stands for the natural log of the raw values. For all variable definitions, see Appendix A. Finally, we include (but do not report) fixed effects for individual clients (C) or audit firms (A), fiscal years (Y), the number of consecutive years the client is with the same audit firm (Audit Firm Tenure, AT), or a client's industry decile rank based on its Return on Assets (Industry-Performance Decile, ID) as indicated. As the estimated coefficients are very small, we multiply Absolute Accruals by 100 in column 1. The table reports OLS coefficient estimates and (in parentheses) $t$-statistics based on robust standard errors clustered by firm (except for column 1 , in which we report robust standard errors clustered by firm). ***, **, and * indicate statistical significance at the 1\%, 5\%, and 10\% levels (two-tailed). 
TABLE 4

Engagement Partner Tenure and Audit Fees

Panel A: Analysis over Partner Tenure Cycle

\begin{tabular}{|c|c|c|c|c|c|}
\hline \multirow[b]{2}{*}{ Dependent Variables: } & (1) & (2) & (3) & (4) & \multirow{2}{*}{$\begin{array}{c}(5) \\
\operatorname{Ln}(\text { Non- } \\
\text { Audit Fees })\end{array}$} \\
\hline & \multicolumn{4}{|c|}{$\operatorname{Ln}($ Audit Fees $)$} & \\
\hline Audit-specific Variables: & & & & & \\
\hline Partner Tenure & $\begin{array}{l}0.003^{* *} \\
(2.56)\end{array}$ & $\begin{array}{l}0.006^{* * * *} \\
(5.73)\end{array}$ & $\begin{array}{l}0.006^{* * * *} \\
(5.80)\end{array}$ & - & $\begin{array}{r}0.006 \\
(0.82)\end{array}$ \\
\hline Tenure Year 1 & - & - & - & $\begin{array}{l}-0.014 * * * \\
(-3.45)\end{array}$ & - \\
\hline Tenure Year 2 & - & - & - & $\begin{array}{l}-0.004 \\
(-1.08)\end{array}$ & - \\
\hline Tenure Year 3 (baseline) & - & - & - & - & - \\
\hline Tenure Year 4 & - & - & - & $\begin{array}{l}0.008 * * \\
(1.99)\end{array}$ & - \\
\hline Tenure Year 5 & - & - & - & $\begin{array}{r}0.007 \\
(1.51)\end{array}$ & - \\
\hline Ln(Audit Hours) & - & $\begin{array}{l}0.404 * * * \\
(20.68)\end{array}$ & $\begin{array}{l}0.403 * * * \\
(20.64)\end{array}$ & $\begin{array}{l}0.404 * * * \\
(20.71)\end{array}$ & $\begin{array}{l}0.269 * * * \\
(5.22)\end{array}$ \\
\hline Client Risk Rating & - & $\begin{array}{c}0.000 \\
(0.10)\end{array}$ & - & $\begin{array}{c}0.000 \\
(0.10)\end{array}$ & $\begin{array}{l}-0.009 \\
(-0.37)\end{array}$ \\
\hline High Client Risk & - & - & $\begin{array}{l}0.016^{* * *} \\
(2.33)\end{array}$ & - & - \\
\hline $\begin{array}{l}\text { Client-specific Controls } \\
\text { Fixed Effects: }\end{array}$ & Yes & Yes & Yes & Yes & Yes \\
\hline $\begin{array}{l}\text { Client }(\mathrm{C}) \\
\text { Year }(\mathrm{Y}) \\
\text { Audit Firm Tenure (AT) }\end{array}$ & $\begin{array}{l}\mathrm{C} \\
\mathrm{Y} \\
\mathrm{AT}\end{array}$ & $\begin{array}{l}\mathrm{C} \\
\mathrm{Y} \\
\mathrm{AT}\end{array}$ & $\begin{array}{l}\mathrm{C} \\
\mathrm{Y} \\
\mathrm{AT}\end{array}$ & $\begin{array}{l}\mathrm{C} \\
\mathrm{Y} \\
\mathrm{AT}\end{array}$ & $\begin{array}{l}\mathrm{C} \\
\mathrm{Y} \\
\mathrm{AT}\end{array}$ \\
\hline R-squared & 0.971 & 0.978 & 0.978 & 0.978 & 0.761 \\
\hline Observations & 17,581 & 17,518 & 17,518 & 17,518 & 14,303 \\
\hline
\end{tabular}


TABLE 4-Continued

Panel B: Audit Fees Conditional on the Competition Among Audit Firms

\begin{tabular}{|c|c|c|c|c|c|c|}
\hline \multirow[b]{3}{*}{ Dependent Variables: Ln(Audit Fees) } & (1) & (2) & (3) & (4) & $(5)$ & $(6)$ \\
\hline & \multicolumn{3}{|c|}{ Competition Index based on Audit Fees } & \multicolumn{3}{|c|}{ Competition Index based on Audit Hours } \\
\hline & $\begin{array}{c}\text { Full } \\
\text { Sample }\end{array}$ & $\begin{array}{c}\text { High } \\
\text { Competition }\end{array}$ & $\begin{array}{c}\text { Low } \\
\text { Competition }\end{array}$ & $\begin{array}{c}\text { Full } \\
\text { Sample }\end{array}$ & $\begin{array}{c}\text { High } \\
\text { Competition }\end{array}$ & $\begin{array}{c}\text { Low } \\
\text { Competition }\end{array}$ \\
\hline \multicolumn{7}{|l|}{ Audit Tenure Variables: } \\
\hline High Competition & $\begin{array}{r}-0.010 \\
(-1.12)\end{array}$ & - & - & $\begin{array}{l}-0.020 * * \\
(-2.14)\end{array}$ & - & - \\
\hline High Competition $\times P T$ & $\begin{array}{l}0.006^{* * * *} \\
(2.82)\end{array}$ & - & - & $\begin{array}{l}0.006 * * * \\
(2.91)\end{array}$ & - & - \\
\hline Partner Tenure $(P T)$ & $\begin{array}{l}0.003 * * \\
(2.12)\end{array}$ & - & - & $\begin{array}{l}0.003 * * \\
(2.07)\end{array}$ & - & - \\
\hline Tenure Year 1 & - & $\begin{array}{l}-0.015^{* *} \\
(-2.56)\end{array}$ & $\begin{array}{l}-0.002 \\
(-0.27)\end{array}$ & - & $\begin{array}{l}-0.015^{* * *} \\
(-2.65)\end{array}$ & $\begin{array}{l}-0.007 \\
(-1.24)\end{array}$ \\
\hline Tenure Year 2, 3, 4 & - & Yes & Yes & - & Yes & Yes \\
\hline Tenure Year 5 & - & $\begin{array}{r}0.008 \\
(1.23)\end{array}$ & $\begin{array}{r}0.008 \\
(1.34)\end{array}$ & - & $\begin{array}{r}0.009 \\
(1.45)\end{array}$ & $\begin{array}{r}0.003 \\
(0.52)\end{array}$ \\
\hline Audit- and Client-specific Controls & Yes & Yes & Yes & Yes & Yes & Yes \\
\hline Fixed Effects & $\mathrm{C}, \mathrm{Y}, \mathrm{AT}$ & $\mathrm{C}, \mathrm{Y}, \mathrm{AT}$ & $\mathrm{C}, \mathrm{Y}, \mathrm{AT}$ & $\mathrm{C}, \mathrm{Y}, \mathrm{AT}$ & $\mathrm{C}, \mathrm{Y}, \mathrm{AT}$ & $\mathrm{C}, \mathrm{Y}, \mathrm{AT}$ \\
\hline R-squared & 0.978 & 0.979 & 0.979 & 0.978 & 0.979 & 0.980 \\
\hline Observations & 17,517 & 8,509 & 8,675 & 17,517 & 8,481 & 8,684 \\
\hline
\end{tabular}

The table reports analyses of the relation between engagement partner tenure and audit prices. We measure audit prices for client $i$ in year $t$ using Audit Fees or, in some specifications, Non-Audit Fees. In Panel A, we report continuous and year-by-year analyses of the evolution of audit fees over the partner tenure cycle. In Panel B, we report analyses of the partner tenure relation conditional on the level of competition among audit firms in the city of the signing partner's office. High Competition is a binary indicator equal to ' 1 ' in year $t$ if the Competition Index measured based either on Audit Fees or Audit Hours falls below the variable median, and '0' otherwise. Our variable of interest, Partner Tenure, reflects the number of consecutive years that the audit partner manages the engagement. For some analyses, we split Partner Tenure into five separate indicators marking the years 1 to 5 of the tenure cycle. Tenure Year 3 serves as base period and lacks a coefficient estimate. The audit- and client-specific control variables are: Ln(Audit Hours), Client Risk Rating, Ln(Market Value), Leverage, Return on Assets in year $t$ and $t$-1, Loss Firm, Cash Flow from Operations, Book-to-Market, Altman Z-Score, Sales Growth, Ln(Cash Flow Volatility), Absolute Accruals, Current Assets, Reporting Lag, Business Segments, and Foreign Sales. Ln stands for the natural log of the raw values. For all variable definitions, see Appendix A. Finally, we include (but do not report) fixed effects for individual clients (C), fiscal years (Y), and the number of consecutive years the client is with the same audit firm (Audit Firm Tenure, AT). The table reports OLS coefficient estimates and (in parentheses) $t$-statistics based on robust standard errors clustered by firm. $* * * * *$, and $*$ indicate statistical significance at the $1 \%, 5 \%$, and $10 \%$ levels (two-tailed). 
TABLE 5

Engagement Partner Tenure and Audit Hours

Panel A: Analysis over Partner Tenure Cycle

\begin{tabular}{|c|c|c|c|c|c|c|}
\hline Dependent Variables: & $\begin{array}{c}(1) \\
\text { Ln(Audit } \\
\text { Hours })\end{array}$ & $\begin{array}{c}(2) \\
\text { Ln(Total } \\
\text { Partner Hours })\end{array}$ & $\begin{array}{c}\text { (3) } \\
\text { Ln(Engagement } \\
\text { Partner Hours })\end{array}$ & $\begin{array}{c}(4) \\
\text { Ln(Audit } \\
\text { Hours })\end{array}$ & $\begin{array}{c}(5) \\
\text { Ln(Total } \\
\text { Partner Hours })\end{array}$ & $\begin{array}{c}(6) \\
\text { Ln(Engagement } \\
\text { Partner Hours })\end{array}$ \\
\hline \multicolumn{7}{|l|}{ Audit-specific Variables: } \\
\hline Partner Tenure & $\begin{array}{l}-0.006^{* * * *} \\
(-4.46)\end{array}$ & $\begin{array}{l}-0.004 \\
(-1.34)\end{array}$ & $\begin{array}{l}-0.043^{* * * *} \\
(-11.41)\end{array}$ & - & - & - \\
\hline Tenure Year 1 & - & - & - & $\begin{array}{l}0.023 * * * \\
(4.37)\end{array}$ & $\begin{array}{l}0.034 * * * \\
(2.98)\end{array}$ & $\begin{array}{l}0.032 * * * \\
(2.63)\end{array}$ \\
\hline Tenure Year 2 & - & - & - & $\begin{array}{l}0.010^{* *} \\
(2.17)\end{array}$ & $\begin{array}{r}0.006 \\
(0.61)\end{array}$ & $\begin{array}{c}0.016 \\
(1.45)\end{array}$ \\
\hline Tenure Year 3 (baseline) & - & - & - & - & - & - \\
\hline Tenure Year 4 & - & - & - & $\begin{array}{l}-0.005 \\
(-0.86)\end{array}$ & $\begin{array}{r}0.000 \\
(0.03)\end{array}$ & $\begin{array}{l}-0.045^{* * *} \\
(-3.96)\end{array}$ \\
\hline Tenure Year 5 & - & - & - & $\begin{array}{r}0.004 \\
(0.67)\end{array}$ & $\begin{array}{l}0.025^{*} \\
(1.89)\end{array}$ & $\begin{array}{l}-0.167^{* * *} \\
(-11.00)\end{array}$ \\
\hline Client Risk Rating & $\begin{array}{l}0.033 * * * \\
(5.77)\end{array}$ & $\begin{array}{l}0.002 \\
(0.26)\end{array}$ & $\begin{array}{l}0.011 \\
(0.71)\end{array}$ & $\begin{array}{l}0.033 * * * \\
(5.77)\end{array}$ & $\begin{array}{r}0.002 \\
(0.25)\end{array}$ & $\begin{array}{r}0.011 \\
(0.67)\end{array}$ \\
\hline $\begin{array}{l}\text { Client-specific Controls } \\
\text { Fixed Effects }\end{array}$ & $\begin{array}{c}\text { Yes } \\
\mathrm{C}, \mathrm{Y}, \mathrm{AT}\end{array}$ & $\begin{array}{c}\text { Yes } \\
\text { C, Y, AT }\end{array}$ & $\begin{array}{c}\text { Yes } \\
\text { C, Y, AT }\end{array}$ & $\begin{array}{c}\text { Yes } \\
\text { C, Y, AT }\end{array}$ & $\begin{array}{c}\text { Yes } \\
\text { C, Y, AT }\end{array}$ & $\begin{array}{c}\text { Yes } \\
\text { C, Y, AT }\end{array}$ \\
\hline $\begin{array}{l}\text { R-squared } \\
\text { Observations }\end{array}$ & $\begin{array}{c}0.944 \\
17,568\end{array}$ & $\begin{array}{c}0.915 \\
10,148\end{array}$ & $\begin{array}{l}0.888 \\
7,145\end{array}$ & $\begin{array}{c}0.945 \\
17,568\end{array}$ & $\begin{array}{c}0.915 \\
10,148\end{array}$ & $\begin{array}{l}0.889 \\
7,145\end{array}$ \\
\hline
\end{tabular}


TABLE 5-Continued

Panel B: Audit Hours around Changes in the Audit Team Composition

\begin{tabular}{|c|c|c|c|c|c|c|}
\hline \multirow[b]{3}{*}{ Dependent Variables: } & (1) & (2) & (3) & (4) & $(5)$ & $(6)$ \\
\hline & \multicolumn{2}{|c|}{$\begin{array}{c}\text { New Review } \\
\text { Partner }\end{array}$} & \multicolumn{2}{|c|}{$\begin{array}{c}\text { New Senior } \\
\text { Manager }\end{array}$} & \multicolumn{2}{|c|}{$\begin{array}{c}\text { New Review Partner } \\
\text { or Senior Manager }\end{array}$} \\
\hline & $\begin{array}{c}\text { New Team } \\
\text { Member }\end{array}$ & $\begin{array}{c}\text { Ln(Audit } \\
\text { Hours })\end{array}$ & $\begin{array}{l}\text { New Team } \\
\text { Member }\end{array}$ & $\begin{array}{l}\mathrm{Ln}(\text { Audit } \\
\text { Hours })\end{array}$ & $\begin{array}{c}\text { New Team } \\
\text { Member }\end{array}$ & $\begin{array}{l}\mathrm{Ln}(\text { Audit } \\
\text { Hours })\end{array}$ \\
\hline \multicolumn{7}{|l|}{ Audit Tenure Variables: } \\
\hline Tenure Year 1 & $\begin{array}{l}0.030 * * \\
(2.48)\end{array}$ & - & $\begin{array}{l}0.067 * * * \\
(5.11)\end{array}$ & - & $\begin{array}{l}0.052 * * * \\
(4.14)\end{array}$ & - \\
\hline Tenure Years 2, 3, 4 & Yes & - & Yes & - & Yes & - \\
\hline Tenure Year 5 & $\begin{array}{l}0.072 * * * \\
(4.72)\end{array}$ & - & $\begin{array}{l}-0.006 \\
(-0.36)\end{array}$ & - & $\begin{array}{l}0.049 * * * \\
(3.30)\end{array}$ & - \\
\hline New Team Member & - & $\begin{array}{r}0.009 \\
(1.02)\end{array}$ & - & $\begin{array}{l}0.024 * * \\
(2.53)\end{array}$ & - & $\begin{array}{l}0.019 * * \\
(2.33)\end{array}$ \\
\hline New Team Member $\times P T$ & - & $\begin{array}{l}-0.001 \\
(-0.21)\end{array}$ & - & $\begin{array}{l}-0.001 \\
(-0.45)\end{array}$ & - & $\begin{array}{l}-0.002 \\
(-0.72)\end{array}$ \\
\hline Partner Tenure (PT) & - & $\begin{array}{l}-0.006^{* * *} \\
(-3.54)\end{array}$ & - & $\begin{array}{l}-0.006^{* * * *} \\
(-3.41)\end{array}$ & - & $\begin{array}{l}-0.005^{* *} \\
(-2.39)\end{array}$ \\
\hline Audit- and Client-specific Controls & Yes & Yes & Yes & Yes & Yes & Yes \\
\hline Fixed Effects & $\mathrm{C}, \mathrm{Y}, \mathrm{AT}$ & $\mathrm{C}, \mathrm{Y}, \mathrm{AT}$ & $\mathrm{C}, \mathrm{Y}, \mathrm{AT}$ & $\mathrm{C}, \mathrm{Y}, \mathrm{AT}$ & $\mathrm{C}, \mathrm{Y}, \mathrm{AT}$ & $\mathrm{C}, \mathrm{Y}, \mathrm{AT}$ \\
\hline R-squared & 0.120 & 0.945 & 0.217 & 0.951 & 0.192 & 0.945 \\
\hline Observations & 17,421 & 17,421 & 15,106 & 15,106 & 17,568 & 17,568 \\
\hline
\end{tabular}

The table reports analyses of the relation between engagement partner tenure and audit effort. We measure audit effort for client $i$ in year $t$ using Audit Hours, Total Partner Hours, or Engagement Partner Hours. In Panel A, we report continuous and year-by-year analyses of the evolution of audit hours over the partner tenure cycle. In Panel B, we report analyses of the partner tenure relation conditional on changes in the audit team composition. New Team Member is a binary indicator and stands for the arrival of a new review partner and/or senior manager, as indicated. In columns (1), we estimate the likelihood of the arrival of a new team member over the partner tenure cycle. In columns (2), we estimate the impact of the arrival of a new team member on audit hours. Our variable of interest, Partner Tenure, reflects the number of consecutive years that the audit partner manages the engagement. For some analyses, we split Partner Tenure into five separate indicators marking the years 1 to 5 of the tenure cycle. Tenure Year 3 serves as base period and lacks a coefficient estimate. We include the same auditand client-specific control variables (except for Audit Hours) and fixed effects as in Table 4. For all variable definitions, see Appendix A. The table reports OLS coefficient estimates and (in parentheses) $t$-statistics based on robust standard errors clustered by firm. $* * *, * *$, and $*$ indicate statistical significance at the $1 \%$, $5 \%$, and $10 \%$ levels (two-tailed). 
TABLE 6

Audit Hours Conditional on Partner Experience and Client Size

\begin{tabular}{|c|c|c|c|c|c|c|}
\hline \multirow{3}{*}{ Dependent Variables: } & (1) & (2) & (3) & (4) & (5) & (6) \\
\hline & \multicolumn{2}{|c|}{$\begin{array}{l}\text { Ln(Engagement } \\
\text { Partner Hours })\end{array}$} & \multicolumn{2}{|c|}{$\begin{array}{c}\text { Ln(Total } \\
\text { Partner Hours })\end{array}$} & \multicolumn{2}{|c|}{$\begin{array}{l}\text { Ln(Engagement } \\
\text { Partner Hours })\end{array}$} \\
\hline & $\begin{array}{l}\text { Newer } \\
\text { Partners }\end{array}$ & $\begin{array}{l}\text { Experienced } \\
\text { Partners }\end{array}$ & $\begin{array}{c}\text { Big } \\
\text { Clients }\end{array}$ & $\begin{array}{l}\text { Small } \\
\text { Clients }\end{array}$ & $\begin{array}{c}\text { Big } \\
\text { Clients }\end{array}$ & $\begin{array}{l}\text { Small } \\
\text { Clients }\end{array}$ \\
\hline \multicolumn{7}{|l|}{ Audit Tenure Variables: } \\
\hline Tenure Year 1 & $\begin{array}{l}0.051^{* *} \\
(2.49)\end{array}$ & $\begin{array}{r}0.014 \\
(0.74)\end{array}$ & $\begin{array}{l}0.036^{* *} \\
(2.29)\end{array}$ & $\begin{array}{l}0.032 * \\
(1.91)\end{array}$ & $\begin{array}{c}0.006 \\
(0.39)\end{array}$ & $\begin{array}{l}0.056 * * * \\
(3.00)\end{array}$ \\
\hline Tenure Year 2 & $\begin{array}{c}0.023 \\
(1.39)\end{array}$ & $\begin{array}{r}0.010 \\
(0.65)\end{array}$ & $\begin{array}{c}0.003 \\
(0.21)\end{array}$ & $\begin{array}{c}0.010 \\
(0.70)\end{array}$ & $\begin{array}{l}0.020 \\
(1.33)\end{array}$ & $\begin{array}{l}0.015 \\
(0.95)\end{array}$ \\
\hline Tenure Year 3 (baseline) & - & - & - & - & - & - \\
\hline Tenure Year 4 & $\begin{array}{l}-0.079 * * * \\
(-4.26)\end{array}$ & $\begin{array}{l}-0.028 * \\
(-1.77)\end{array}$ & $\begin{array}{r}0.008 \\
(0.51)\end{array}$ & $\begin{array}{l}-0.022 \\
(-1.26)\end{array}$ & $\begin{array}{l}-0.027 * \\
(-1.83)\end{array}$ & $\begin{array}{l}-0.075^{* * * *} \\
(-4.16)\end{array}$ \\
\hline Tenure Year 5 & $\begin{array}{l}-0.201 * * * \\
(-7.59)\end{array}$ & $\begin{array}{l}-0.137 * * * \\
(-6.19)\end{array}$ & $\begin{array}{l}0.036^{* *} \\
(1.97)\end{array}$ & $\begin{array}{r}0.006 \\
(0.29)\end{array}$ & $\begin{array}{l}-0.169 * * * \\
(-8.70)\end{array}$ & $\begin{array}{l}-0.171^{* * * *} \\
(-6.83)\end{array}$ \\
\hline $\begin{array}{l}\text { Audit- and Client-specific Controls } \\
\text { Fixed Effects }\end{array}$ & $\begin{array}{c}\text { Yes } \\
\mathrm{C}, \mathrm{Y}, \mathrm{AT}\end{array}$ & $\begin{array}{c}\text { Yes } \\
\text { C, Y, AT }\end{array}$ & $\begin{array}{c}\text { Yes } \\
\text { C, Y, AT }\end{array}$ & $\begin{array}{c}\text { Yes } \\
\text { C, Y, AT }\end{array}$ & $\begin{array}{c}\text { Yes } \\
\text { C, Y, AT }\end{array}$ & $\begin{array}{c}\text { Yes } \\
\text { C, Y, AT }\end{array}$ \\
\hline $\begin{array}{l}\text { R-squared } \\
\text { Observations }\end{array}$ & $\begin{array}{l}0.891 \\
3,315\end{array}$ & $\begin{array}{l}0.924 \\
2,972\end{array}$ & $\begin{array}{l}0.910 \\
5,056\end{array}$ & $\begin{array}{l}0.835 \\
4,960\end{array}$ & $\begin{array}{l}0.877 \\
3,592\end{array}$ & $\begin{array}{l}0.839 \\
3,383\end{array}$ \\
\hline
\end{tabular}

The table reports analyses of the partner tenure relation conditional on partner experience and client size. We distinguish between (i) newer versus more experienced audit engagement partners based on the number of years since they were granted partnership (Partner Experience), and (ii) big versus small audit clients (Total Assets). In both cases, we estimate the model separately after splitting the sample by the partitioning variable median. We measure audit effort for client $i$ in year $t$ using Total Partner Hours and Engagement Partner Hours. We split our variable of interest, Partner Tenure, into five separate indicators marking the years 1 to 5 of the tenure cycle. Tenure Year 3 serves as base period and lacks a coefficient estimate. We include the same audit- and client-specific control variables and fixed effects as in Table 5. For all variable definitions, see Appendix A. The table reports OLS coefficient estimates and (in parentheses) $t$ statistics based on robust standard errors clustered by firm. $* * *, * *$, and $*$ indicate statistical significance at the $1 \%, 5 \%$, and $10 \%$ levels (two-tailed). 
TABLE 7

Audit Economics and Audit Quality Around Audit Firm Switches and Audit Team Rotations

Panel A: Audit Firm Switches

\begin{tabular}{|c|c|c|c|c|c|c|c|c|}
\hline \multirow[b]{3}{*}{ Dependent Variables: } & (1) & (2) & (3) & (4) & (5) & (6) & (7) & (8) \\
\hline & \multicolumn{3}{|c|}{ Proxies for Audit Economics } & \multicolumn{5}{|c|}{ Proxies for Audit Quality } \\
\hline & $\begin{array}{c}\mathrm{Ln}(\text { Audit } \\
\text { Fees })\end{array}$ & $\begin{array}{c}\mathrm{Ln}(\text { Audit } \\
\text { Hours })\end{array}$ & $\begin{array}{l}\mathrm{Ln}(\text { Engage- } \\
\text { ment Partner } \\
\text { Hours })\end{array}$ & $\begin{array}{l}\text { Restated } \\
\text { Financials }\end{array}$ & $\begin{array}{l}\text { Announced } \\
\text { Restate- } \\
\text { ment }\end{array}$ & $\begin{array}{c}404 b \\
\text { Opinion } \\
\text { with MCW }\end{array}$ & $\begin{array}{l}\text { PCAOB } \\
\text { Inspection } \\
\text { Finding }\end{array}$ & $\begin{array}{l}\text { Audit Firm } \\
\text { Inspection } \\
\text { Finding }\end{array}$ \\
\hline \multirow[t]{2}{*}{ Audit Firm Switch Cycle } & $-0.177 * * *$ & $0.113 * * *$ & 0.044 & -0.032 & 0.004 & $0.202 * * *$ & $0.153 * *$ & 0.041 \\
\hline & $(-7.34)$ & $(3.54)$ & $(0.76)$ & $(-0.96)$ & $(0.19)$ & $(3.52)$ & $(2.10)$ & $(0.65)$ \\
\hline \multirow{2}{*}{ Audit Firm Switch Cycle $\times P T$} & $0.025 * * *$ & $-0.017 * *$ & -0.019 & 0.003 & -0.004 & $-0.038 * *$ & -0.043 & -0.033 \\
\hline & (3.97) & $(-2.05)$ & $(-1.16)$ & $(0.26)$ & $(-0.53)$ & $(-1.97)$ & $(1.50)$ & $(-1.40)$ \\
\hline \multirow[t]{2}{*}{ Partner Tenure (PT) } & $0.005 * * *$ & $-0.006 * * *$ & $-0.042 * * *$ & -0.000 & $-0.004 * * *$ & -0.001 & 0.011 & 0.003 \\
\hline & $(5.30)$ & $(-4.64)$ & $(-10.93)$ & $(-0.20)$ & $(-3.00)$ & $(-0.24)$ & $(1.31)$ & $(0.42)$ \\
\hline Audit- and Client-specific Controls & Yes & Yes & Yes & Yes & Yes & Yes & Yes & Yes \\
\hline Fixed Effects & $\mathrm{C}, \mathrm{Y}$ & $\mathrm{C}, \mathrm{Y}$ & $\mathrm{C}, \mathrm{Y}$ & $\mathrm{C}, \mathrm{Y}$ & $\mathrm{C}, \mathrm{Y}$ & $\mathrm{A} \times \mathrm{Y}$ & $\mathrm{A} \times \mathrm{Y}$ & $\mathrm{A} \times \mathrm{Y}$ \\
\hline R-squared & 0.978 & 0.944 & 0.887 & 0.500 & 0.218 & 0.079 & 0.125 & 0.212 \\
\hline Observations & 17,519 & 17,569 & 7,142 & 17,609 & 17,602 & 2,889 & 1,553 & 1,799 \\
\hline \multicolumn{9}{|l|}{ Panel B: Audit Team Rotations } \\
\hline \multirow[t]{2}{*}{ Audit Team Rotation Cycle } & -0.007 & $0.034 * * *$ & 0.028 & $0.029 * *$ & $0.020 * *$ & $0.059 * *$ & 0.060 & 0.027 \\
\hline & $(-0.93)$ & $(3.12)$ & $(0.97)$ & $(2.20)$ & $(2.16)$ & $(2.30)$ & $(1.12)$ & $(0.60)$ \\
\hline \multirow[t]{2}{*}{ Audit Team Rotation Cycle $\times P T$} & $0.004 *$ & $-0.011 * * *$ & 0.004 & -0.006 & -0.003 & $-0.019 * *$ & -0.015 & -0.004 \\
\hline & $(1.72)$ & $(-3.38)$ & $(0.45)$ & $(-1.48)$ & $(-1.16)$ & $(-2.15)$ & $(-0.77)$ & $(-0.26)$ \\
\hline \multirow[t]{2}{*}{ Partner Tenure $(P T)$} & $0.004 * * *$ & -0.001 & $-0.043 * * *$ & 0.002 & -0.002 & 0.006 & 0.013 & 0.004 \\
\hline & $(3.34)$ & $(-0.66)$ & $(-8.00)$ & $(0.99)$ & $(-1.38)$ & $(1.16)$ & $(1.15)$ & $(0.37)$ \\
\hline Audit- and Client-specific Controls & Yes & Yes & Yes & Yes & Yes & Yes & Yes & Yes \\
\hline Fixed Effects & $\mathrm{C}, \mathrm{Y}, \mathrm{AT}$ & $\mathrm{C}, \mathrm{Y}, \mathrm{AT}$ & $\mathrm{C}, \mathrm{Y}, \mathrm{AT}$ & $\mathrm{C}, \mathrm{Y}, \mathrm{AT}$ & $\mathrm{C}, \mathrm{Y}, \mathrm{AT}$ & $\mathrm{A} \times \mathrm{Y}, \mathrm{AT}$ & $\mathrm{A} \times \mathrm{Y}, \mathrm{AT}$ & $\mathrm{A} \times \mathrm{Y}, \mathrm{AT}$ \\
\hline R-squared & 0.978 & 0.945 & 0.888 & 0.504 & 0.220 & 0.095 & 0.138 & 0.226 \\
\hline Observations & 17,372 & 17,421 & 7,120 & 17,509 & 17,502 & 2,881 & 1,539 & 1,792 \\
\hline
\end{tabular}

The table reports analyses of the partner tenure relation conditional on the client switching the audit firm (Panel A) or the auditor rotating the audit team (Panel B). We identify audit firm switches based on the opinion data in Audit Analytics. We define audit team rotations as years when the engagement partner and either the review partner or a senior manager arrive at a new (but not necessarily from the same) client. We use various proxies of audit economics (i.e., fees and hours) and audit quality as the dependent variables. Audit Firm Switch Cycle and Audit Team Rotation Cycle are binary indicators marking the entire (initial) partner tenure cycle under the new audit firm and the new audit team, respectively. Our variable of interest, Partner Tenure, reflects the number of consecutive years that the audit partner manages the engagement. We include the respective audit- and client-specific control variables and fixed effects as in Tables 3,4 , and 5. For variable definitions, see Appendix A. The table reports OLS coefficient estimates and (in parentheses) $t$-statistics based on robust standard errors clustered by firm. ***, **, and * indicate statistical significance at the $1 \%, 5 \%$, and $10 \%$ levels (two-tailed). 
TABLE 8

Audit Economics and Audit Quality Around Non-Mandatory Rotations of Engagement Partners $(<5-Y e a r)$

Panel A: Average Effects around Non-Mandatory Rotations

\begin{tabular}{|c|c|c|c|c|c|c|c|c|}
\hline \multirow[b]{3}{*}{ Dependent Variables: } & (1) & (2) & (3) & (4) & (5) & (6) & (7) & (8) \\
\hline & \multicolumn{3}{|c|}{ Proxies for Audit Economics } & \multicolumn{5}{|c|}{ Proxies for Audit Quality } \\
\hline & $\begin{array}{c}\mathrm{Ln}(\text { Audit } \\
\text { Fees })\end{array}$ & $\begin{array}{c}\mathrm{Ln}(\text { Audit } \\
\text { Hours })\end{array}$ & $\begin{array}{c}\text { Ln(Engage- } \\
\text { ment Partner } \\
\text { Hours })\end{array}$ & $\begin{array}{c}\text { Restated } \\
\text { Financials }\end{array}$ & $\begin{array}{l}\text { Announced } \\
\text { Restate- } \\
\text { ment }\end{array}$ & $\begin{array}{c}404 b \\
\text { Opinion } \\
\text { with } M C W\end{array}$ & $\begin{array}{l}P C A O B \\
\text { Inspection } \\
\text { Finding }\end{array}$ & $\begin{array}{c}\text { Audit Firm } \\
\text { Inspection } \\
\text { Finding }\end{array}$ \\
\hline \multirow[t]{2}{*}{ Year before Non-Mandatory Rotation } & 0.001 & 0.011 & $-0.089 * * *$ & $0.024 * *$ & $0.015^{*}$ & $0.036 *$ & 0.059 & -0.029 \\
\hline & $(0.09)$ & $(1.21)$ & $(-3.29)$ & $(2.27)$ & $(1.90)$ & $(1.87)$ & $(1.32)$ & $(-0.80)$ \\
\hline \multirow[t]{2}{*}{ Year after Non-Mandatory Rotation } & -0.006 & $0.028 * * *$ & 0.009 & 0.008 & 0.006 & -0.029 & -0.004 & -0.026 \\
\hline & $(-0.83)$ & $(2.88)$ & $(0.41)$ & $(0.70)$ & $(0.65)$ & $(-1.30)$ & $(-0.08)$ & $(-0.63)$ \\
\hline \multirow[t]{2}{*}{ Year before Audit Firm Switch } & 0.020 & $0.078 * * *$ & 0.050 & $0.043 * *$ & $0.045^{* * *}$ & $0.183 * * *$ & 0.119 & -0.006 \\
\hline & $(1.25)$ & $(4.08)$ & $(1.54)$ & $(2.09)$ & $(2.64)$ & $(4.06)$ & $(1.50)$ & $(-0.08)$ \\
\hline \multirow[t]{2}{*}{ Tenure Year 1} & $-0.012 * * *$ & $0.015^{* * *}$ & 0.014 & 0.007 & $0.014 * *$ & $0.054 * * *$ & -0.049 & 0.003 \\
\hline & $(-2.79)$ & $(2.61)$ & $(1.01)$ & $(0.91)$ & $(2.30)$ & $(2.65)$ & $(-1.26)$ & $(0.08)$ \\
\hline Tenure Year 2 to 5 & Yes & Yes & Yes & Yes & Yes & Yes & Yes & Yes \\
\hline Audit- and Client-specific Controls & Yes & Yes & Yes & Yes & Yes & Yes & Yes & Yes \\
\hline Fixed Effects & $\mathrm{C}, \mathrm{Y}, \mathrm{AT}$ & $\mathrm{C}, \mathrm{Y}, \mathrm{AT}$ & $\mathrm{C}, \mathrm{Y}, \mathrm{AT}$ & $\mathrm{C}, \mathrm{Y}, \mathrm{AT}$ & $\mathrm{C}, \mathrm{Y}, \mathrm{AT}$ & $\mathrm{A} \times \mathrm{Y}, \mathrm{AT}$ & $\mathrm{A} \times \mathrm{Y}, \mathrm{AT}$ & $\mathrm{A} \times \mathrm{Y}, \mathrm{AT}$ \\
\hline R-squared & 0.978 & 0.945 & 0.890 & 0.502 & 0.222 & 0.107 & 0.143 & 0.226 \\
\hline Observations & 17,518 & 17,568 & 7,145 & 17,660 & 17,653 & 2,903 & 1,560 & 1,801 \\
\hline \multicolumn{9}{|c|}{ Panel B: Distinction between Explainable and Unexplained Non-Mandatory Rotations } \\
\hline Year before Non-Mandatory & 0.001 & $0.025^{*}$ & $-0.116 * * *$ & 0.021 & 0.007 & 0.016 & -0.043 & -0.085 \\
\hline Rotation $_{\text {expl }}$ & $(0.09)$ & $(1.81)$ & $(-3.22)$ & $(1.14)$ & $(0.46)$ & $(0.45)$ & $(-0.53)$ & $(-1.30)$ \\
\hline Year before Non-Mandatory & 0.000 & 0.006 & $-0.076 * *$ & $0.026 * *$ & $0.018 * *$ & $0.044 *$ & $0.095^{*}$ & -0.007 \\
\hline Rotation $_{\text {unexpl }}$ & $(0.05)$ & $(0.57)$ & $(-2.22)$ & $(2.16)$ & $(2.08)$ & $(1.93)$ & $(1.84)$ & $(-0.16)$ \\
\hline Tenure Year 1 to 5 & Yes & Yes & Yes & Yes & Yes & Yes & Yes & Yes \\
\hline Audit- and Client-specific Controls & Yes & Yes & Yes & Yes & Yes & Yes & Yes & Yes \\
\hline Fixed Effects & $\mathrm{C}, \mathrm{Y}, \mathrm{AT}$ & $\mathrm{C}, \mathrm{Y}, \mathrm{AT}$ & $\mathrm{C}, \mathrm{Y}, \mathrm{AT}$ & $\mathrm{C}, \mathrm{Y}, \mathrm{AT}$ & $\mathrm{C}, \mathrm{Y}, \mathrm{AT}$ & $\mathrm{A} \times \mathrm{Y}, \mathrm{AT}$ & $\mathrm{A} \times \mathrm{Y}, \mathrm{AT}$ & $\mathrm{A} \times \mathrm{Y}, \mathrm{AT}$ \\
\hline R-squared & 0.978 & 0.945 & 0.890 & 0.502 & 0.222 & 0.107 & 0.145 & 0.226 \\
\hline Observations & 17,518 & 17,568 & 7,145 & 17,660 & 17,653 & 2,903 & 1,560 & 1,801 \\
\hline
\end{tabular}


TABLE 8-Continued

Panel C: Various PCAOB Inspection Outcomes around Explainable and Unexplained Non-Mandatory Rotations

\begin{tabular}{|c|c|c|c|c|c|}
\hline & (1) & (2) & (3) & (4) & (5) \\
\hline Dependent Variables: & $\begin{array}{c}\text { Part I Finding } \\
\text { (PCAOB Inspection } \\
\text { Finding) }\end{array}$ & $\begin{array}{c}\text { Contributing } \\
\text { Part II } \\
\text { Finding }\end{array}$ & $\begin{array}{c}\operatorname{Ln}(1+\# \text { Part I } \\
\text { Findings + \# Contr. } \\
\text { Part II Findings })\end{array}$ & $\begin{array}{l}\text { Severe } \\
\text { Inspection } \\
\text { Finding }\end{array}$ & $\begin{array}{l}\text { Non-Severe } \\
\text { Inspection } \\
\text { Finding }\end{array}$ \\
\hline \multirow[t]{2}{*}{ Year before Non-Mandatory Rotation ${ }_{\text {expl }}$} & -0.043 & -0.066 & 0.012 & 0.022 & -0.063 \\
\hline & $(-0.53)$ & $(-0.79)$ & $(0.07)$ & $(0.28)$ & $(-0.81)$ \\
\hline \multirow[t]{2}{*}{ Year before Non-Mandatory Rotation ${ }_{\text {unexpl }}$} & $0.095^{*}$ & 0.064 & $0.205^{*}$ & $0.155^{* * *}$ & -0.065 \\
\hline & $(1.84)$ & $(1.21)$ & $(1.95)$ & $(3.18)$ & $(-1.32)$ \\
\hline Tenure Year 1 to 5 & Yes & Yes & Yes & Yes & Yes \\
\hline Audit- and Client-specific Controls & Yes & Yes & Yes & Yes & Yes \\
\hline Fixed Effects & $\mathrm{A} \times \mathrm{Y}, \mathrm{AT}$ & $\mathrm{A} \times \mathrm{Y}, \mathrm{AT}$ & $\mathrm{A} \times \mathrm{Y}, \mathrm{AT}$ & $\mathrm{A} \times \mathrm{Y}, \mathrm{AT}$ & $\mathrm{A} \times \mathrm{Y}, \mathrm{AT}$ \\
\hline R-squared & 0.145 & 0.163 & 0.167 & 0.124 & 0.141 \\
\hline Observations & 1,560 & 1,560 & 1,560 & 1,560 & 1,560 \\
\hline
\end{tabular}

The table reports analyses of the partner tenure relation around non-mandatory rotations. A non-mandatory rotation occurs when the engagement partner leaves a client short of the regular 5-year rotation cycle (i.e., during years 1 to 4 of her tenure) and is replaced by another partner from within the same audit firm. We use various proxies of audit economics (i.e., fees and hours) and audit quality as the dependent variables. In Panel A, we distinguish between the Year before Non-Mandatory Rotation, the Year after Non-Mandatory Rotation, and the Year before Audit Firm Switch by introducing binary indicators in the model that mark the respective time periods in the auditor-client relationship. In Panels B and C, we partition the Year before Non-Mandatory Rotation variable into rotations that can be explained by scheduled retirements, promotions, office switches, or temporary leaves (as indicated by the subscript expl) and all the other, unexplained rotations (unexpl). In Panel C, we examine different types of PCAOB inspection findings and classify them as Severe if the PCAOB inspection determines that (i) both the financial statement and internal control opinions are not supported or (ii) the client has a likely departure from GAAP. We split our variable of interest, Partner Tenure, into five separate indicators marking the years 1 to 5 of the tenure cycle. We include the respective audit- and client-specific control variables and fixed effects as in Tables 3, 4, and 5. For variable definitions, see Appendix A. The table reports OLS coefficient estimates and (in parentheses) $t$ statistics based on robust standard errors clustered by firm. ***,**, and * indicate statistical significance at the $1 \%, 5 \%$, and $10 \%$ levels (two-tailed). 


\section{APPENDIX A \\ Variable Definitions}

Panel A: Variables of Interest

\begin{tabular}{|l|l|}
\hline Variable Name & Definition \\
\hline $\begin{array}{l}\text { Partner Tenure } \\
\text { (years) }\end{array}$ & $\begin{array}{l}\text { The ordered variable reflects the number of consecutive years that the audit } \\
\text { partner manages the engagement, and ranges from 1 to 5. We determine a } \\
\text { partner's tenure cycle based on (i) the disclosed tenure information from the audit } \\
\text { firm, and (ii) the observed partner history in the data following a switch in } \\
\text { engagements. If information is missing, we assume a partner rotation after year 5. } \\
\text { Data source: proprietary data submitted to the PCAOB. }\end{array}$ \\
\hline $\begin{array}{l}\text { Review Partner Tenure } \\
\text { (years) }\end{array}$ & $\begin{array}{l}\text { Measured the same way as Partner Tenure, but with regard to the partner that } \\
\text { reviews the audit engagement. Data source: proprietary data submitted to the } \\
\text { PCAOB. }\end{array}$ \\
\hline $\begin{array}{l}\text { Tenure Year 1 through } \\
\text { Tenure Year 5 } 5\end{array}$ & $\begin{array}{l}\text { A set of five indicator variables marking the years 1 through 5 of the tenure cycle } \\
\text { (hat the (review) partner manages (spends reviewing) the audit engagement. That } \\
\text { is, the indicator is set equal to '1' in the respective year of the tenure cycle based } \\
\text { on the variables Partner Tenure or Review Partner Tenure. }\end{array}$ \\
\hline
\end{tabular}

Panel B: Audit Quality Variables

\begin{tabular}{|c|c|}
\hline Variable Name & Definition \\
\hline $\begin{array}{l}\text { Absolute Accruals } \\
\text { (\% of assets) }\end{array}$ & $\begin{array}{l}\text { The variable is equal to the absolute value of (Net Income }- \text { Cash Flows from } \\
\left.\left.\text { Operations) / ((Total Assets } s_{t}+\text { Total Assets } s_{t-1}\right) / 2\right) \text { of firm } i \text { in year } t \text {. Data source: } \\
\text { Compustat. }\end{array}$ \\
\hline $\begin{array}{l}\text { Restated Financials } \\
\text { (indicator) }\end{array}$ & $\begin{array}{l}\text { We set the binary indicator equal to ' } 1 \text { ' in year } t \text { if subsequently the client's } \\
\text { audited annual financial statements ( } 10-\mathrm{K} \text { ) for fiscal year } t \text { are restated, and ' } 0 \text { ' } \\
\text { otherwise. We exclude quarterly restatements (except for the fourth quarter) when } \\
\text { coding this variable. Data source: Audit Analytics. }\end{array}$ \\
\hline $\begin{array}{l}\text { Announced Restatement } \\
\text { (indicator) }\end{array}$ & $\begin{array}{l}\text { We set the binary indicator equal to ' } 1 \text { ' in year } t \text { if a restatement of prior (i.e., }<t \text { ) } \\
\text { audited annual financial statements is announced between the filing of last year's } \\
10-\mathrm{K}_{t-1} \text { and the filing of this year's } 10-\mathrm{K}_{\mathrm{t}} \text {, and ' } 0 \text { ' otherwise. Compared to } \\
\text { Restated Financials, this definition results in a subsequent fiscal year being coded } \\
\text { as ' } 1 \text { '. Data source: Audit Analytics. }\end{array}$ \\
\hline $\begin{array}{l}404 b \text { Opinion with } M C W \\
\text { (indicator) }\end{array}$ & $\begin{array}{l}\text { We set the binary indicator equal to ' } 1 \text { ' in year } t \text { if the auditor finds or agrees with } \\
\text { the client's assertion that internal controls over financial reporting exhibit some } \\
\text { material control weaknesses (MCW) or qualifies the client's internal control } \\
\text { opinion for fiscal year } t \text {, and ' } 0 \text { ' otherwise. This variable is only coded for client- } \\
\text { years that were subsequently restated (i.e., Restated Financials }=1 \text { ). MCW is } \\
\text { defined by PCAOB auditing standard } 2201 \text { (pre-codified AS5). Data source: } \\
\text { Audit Analytics. }\end{array}$ \\
\hline $\begin{array}{l}\text { PCAOB Inspection Finding } \\
\text { also called: Part I Finding } \\
\text { (indicator) }\end{array}$ & $\begin{array}{l}\text { We set the binary indicator equal to ' } 1 \text { ' in year } t \text { if the PCAOB inspections of } \\
\text { clients' audits of fiscal year } t \text { resulted in any Part } 1 \text { findings (i.e. disclosed } \\
\text { anonymously in the audit firm's publicly available inspection report), and ' } 0 \text { ' } \\
\text { otherwise. The PCAOB inspection will include a Part } 1 \text { finding when the work } \\
\text { performed by the auditor does not support the opinion. This variable is only coded } \\
\text { for client-years that were subject to PCAOB inspections. Data source: proprietary } \\
\text { data generated by the PCAOB. }\end{array}$ \\
\hline $\begin{array}{l}\text { Contributing Part II } \\
\text { Finding } \\
\text { (indicator) }\end{array}$ & $\begin{array}{l}\text { We set the binary indicator equal to ' } 1 \text { ' in year } t \text { if the PCAOB inspections of } \\
\text { clients' audits of fiscal year } t \text { resulted in any findings that contributed to the } \\
\text { content of an audit firm's Part II report (i.e., describing deficiencies of the audit } \\
\text { firm's overall system of quality control), and '0' otherwise. This variable is only } \\
\text { coded for client-years that were subject to PCAOB inspections. In some analyses, } \\
\text { we are also using the log-transformed sum of the number of Part I and Part II } \\
\text { findings (plus 1) as dependent variable. Data source: proprietary data generated } \\
\text { by the PCAOB. }\end{array}$ \\
\hline
\end{tabular}




\begin{tabular}{|l|l|}
\hline Variable Name & Definition \\
\hline $\begin{array}{l}\text { Severe (Non-Severe) } \\
\text { Inspection Finding } \\
\text { (indicator) }\end{array}$ & $\begin{array}{l}\text { We set the Severe Inspection Finding binary indicator to '1' in year } t \text { if the } \\
\text { PCAOB concludes from the inspection that (i) both financial statements and } \\
\text { internal controls opinions were unsupported by the audit work or (ii) the client } \\
\text { firm had likely GAAP deficiencies that could result in material misstatements in } \\
\text { years not inspected by the PCAOB. The Non-Severe Inspection Finding indicator } \\
\text { equals '1' for any other inspection finding. We note that, in practice, the PCAOB } \\
\text { does not distinguish the severity of an inspection finding (see also footnote 41). } \\
\text { This variable is only coded for client-years that were subject to PCAOB } \\
\text { inspections. Data source: proprietary data generated by the PCAOB. }\end{array}$ \\
\hline $\begin{array}{l}\text { Audit Firm Inspection } \\
\text { Finding } \\
\text { indicator) }\end{array}$ & $\begin{array}{l}\text { We set the binary indicator equal to '1' in year } \text { tif an audit firm's internal } \\
\text { inspections resulted in some type of finding, and '0' otherwise. Audit firms } \\
\text { review audits internally and report the results, that is, no finding, minor finding(s) } \\
\text { (e.g., add additional documentation), and major finding(s) (e.g., failed to perform } \\
\text { sufficient audit work) to the PCAOB. This variable is only coded for client-years } \\
\text { that were subject to audit firms' internal inspections. Data source: proprietary data } \\
\text { submitted to the PCAOB. }\end{array}$ \\
\hline
\end{tabular}

Panel C: Audit Economics Variables

\begin{tabular}{|l|l|}
\hline Variable Name & Definition \\
\hline $\begin{array}{l}\text { Audit Fees } \\
\text { \$ thousand) }\end{array}$ & $\begin{array}{l}\text { Total fees for auditing (MATCHFY_SUM_AUDFEES) and audit related activities } \\
\text { (MATCHFY_SUM_AUDREL_FEES) paid by client } i \text { in year } t \text {. Data source: Audit } \\
\text { Analytics. }\end{array}$ \\
\hline $\begin{array}{l}\text { Non-Audit Fees } \\
\text { (\$ thousand) }\end{array}$ & $\begin{array}{l}\text { We interpret non-audit fees as total fees (MATCHFY_SUM_TOTAL) minus those } \\
\text { for auditing and audit related activities (see Audit Fees above) paid by client } i \text { in } \\
\text { year } t \text {. Data source: Audit Analytics. }\end{array}$ \\
\hline $\begin{array}{l}\text { Audit Hours } \\
\text { (hours) }\end{array}$ & $\begin{array}{l}\text { Total number of auditing hours, including both staff and partner hours, performed } \\
\text { for client } i \text { in year } t \text {. Data source: proprietary data submitted to the PCAOB. }\end{array}$ \\
\hline $\begin{array}{l}\text { Total Partner Hours } \\
\text { (hours) }\end{array}$ & $\begin{array}{l}\text { Total hours that all partners performed for client } i \text { in year } t \text { (i.e., engagement } \\
\text { partner, review partner, IT partner, tax partner, specialist partner, etc.). This } \\
\text { variable is only available for 2008 to 2011. Data source: proprietary data } \\
\text { submitted to the PCAOB. }\end{array}$ \\
\hline $\begin{array}{l}\text { Engagement Partner Hours } \\
\text { (hours) }\end{array}$ & $\begin{array}{l}\text { Total hours that the engagement partner performed for client } i \text { in year } t \text {. This } \\
\text { variable is only available for 2012 to 2014. Data source: proprietary data } \\
\text { submitted to the PCAOB. }\end{array}$ \\
\hline $\begin{array}{l}\text { Review Partner Hours } \\
\text { (hours) }\end{array}$ & $\begin{array}{l}\text { Total hours that the review partner performed reviewing the engagement partner's } \\
\text { work for client } i \text { in year } t \text {. Data source: proprietary data submitted to the PCAOB. }\end{array}$ \\
\hline $\begin{array}{l}\text { Billing Realization } \\
\text { (percentage) }\end{array}$ & $\begin{array}{l}\text { Audit fees divided by the "sticker price" of the audit performed for client } i \text { in year } \\
t . \text { The sticker price of an audit is the sum of the billing rate for all staff (including } \\
\text { the partner) multiplied by the total hours that all staff (including the partner) spent } \\
\text { on the engagement. For instance, a Billing Realization of } 40 \text { indicates that with a } \\
\text { staff (partner) bill rate of \$300 (\$800) per hour, the final, negotiated audit fee } \\
\text { results in the audit firm receiving an average of \$120 (\$320) per actual staff } \\
\text { (partner) hour. Data source: proprietary data submitted to the PCAOB. }\end{array}$ \\
\hline
\end{tabular}

Panel D: Other Audit Variables

\begin{tabular}{|l|l|}
\hline Variable Name & Definition \\
\hline $\begin{array}{l}\text { Client Risk Rating } \\
\text { (score) }\end{array}$ & $\begin{array}{l}\text { The variable is the normalized version of the risk rating that the audit firms assign } \\
\text { to client } i \text { in year } t \text {, and ranges from 1 to 5. Each audit firm has its own rating } \\
\text { system. To make risk ratings comparable, we normalize them by dividing them } \\
\text { into rank ordered quintiles per audit firm. Higher values indicate higher perceived } \\
\text { audit risks. Data source: proprietary data submitted to the PCAOB. }\end{array}$ \\
\hline $\begin{array}{l}\text { High Client Risk } \\
\text { (indicator) }\end{array}$ & $\begin{array}{l}\text { We set the binary indicator equal to '1' in year } t \text { if the Client Risk Rating variable } \\
\text { equals } 4 \text { or 5, and '0' otherwise. }\end{array}$ \\
\hline
\end{tabular}




\begin{tabular}{|c|c|}
\hline Variable Name & Definition \\
\hline $\begin{array}{l}\text { Partner Experience } \\
\text { (years) }\end{array}$ & $\begin{array}{l}\text { We compute a partner's experience in year } t \text { as the calendar year } t \text { minus the year } \\
\text { she was granted partnership at the firm. Data source: the year of partnership is } \\
\text { proprietary data submitted to the PCAOB. }\end{array}$ \\
\hline Competition Index (\%) & $\begin{array}{l}\text { We compute the Herfindahl index (i.e., sum of squared market shares) using the } \\
\text { Audit Fees charged to clients (Audit Hours performed) by an individual audit firm } \\
\text { in year } t \text { as percent of the total Audit Fees (Audit Hours) by all audit firms in a } \\
\text { signing city (i.e., the location of the signing partner's office) in year } t \text { as our proxy } \\
\text { for market share. Higher values indicate less competition in a city. Data source: } \\
\text { Audit Analytics for fees and proprietary data submitted to the PCAOB for hours. }\end{array}$ \\
\hline $\begin{array}{l}\text { New Review Partner } \\
\text { (indicator) }\end{array}$ & $\begin{array}{l}\text { We set the binary indicator equal to ' } 1 \text { ' in year } t \text { if the review partner has } \\
\text { switched between years } t-1 \text { and } t \text {, and ' } 0 \text { ' otherwise. Data source: proprietary data } \\
\text { submitted to the PCAOB. }\end{array}$ \\
\hline $\begin{array}{l}\text { New Senior Manager } \\
\text { (indicator) }\end{array}$ & $\begin{array}{l}\text { We set the binary indicator equal to ' } 1 \text { ' in year } t \text { if any senior manager has } \\
\text { switched between years } t-1 \text { and } t \text {, and ' } 0 \text { ' otherwise. Clients can have more than } \\
\text { one senior manager. Data source: proprietary data submitted to the PCAOB. }\end{array}$ \\
\hline $\begin{array}{l}\text { Audit Firm Switch } \\
\text { Audit Firm Switch Cycle } \\
\text { (indicator) }\end{array}$ & $\begin{array}{l}\text { We set the binary indicator equal to ' } 1 \text { ' in year } t \text { if the signing audit firm changes } \\
\text { from year } t-1 \text { to } t \text {, and ' } 0 \text { ' otherwise. For Audit Firm Switch Cycle, we code the } \\
\text { entire initial partner cycle (i.e., years } t \text { up to } t+4 \text { ) as ' } 1 \text { ' following an Audit Firm } \\
\text { Switch. Data source: the audit firm identifier (AUDITOR_FKEY) in Audit } \\
\text { Analytics and proprietary data submitted to the PCAOB. }\end{array}$ \\
\hline $\begin{array}{l}\text { Audit Team Rotation } \\
\text { Audit Team Rotation Cycle } \\
\text { (indicator) }\end{array}$ & $\begin{array}{l}\text { We set the binary indicator equal to ' } 1 \text { ' in year } t \text { if the engagement partner and } \\
\text { either the review partner or any senior manager have newly arrived at client } i \text { in } \\
\text { year } t \text { (but not necessarily from the same client), and ' } 0 \text { ' otherwise. For Audit } \\
\text { Team Rotation Cycle, we code the entire partner cycle (i.e., years } t \text { up to } t+4 \text { ) as } \\
\text { ' } 1 \text { ' following an Audit Team Rotation. If both the lead and the review partners } \\
\text { newly arrived at the client, we require them to stay together on the engagement } \\
\text { for the coding of Audit Team Rotation Cycle. Data source: proprietary data } \\
\text { submitted to the PCAOB. }\end{array}$ \\
\hline $\begin{array}{l}\text { Year before Non-Mandatory } \\
\text { Rotation } \\
\text { (indicator) }\end{array}$ & $\begin{array}{l}\text { We set the binary indicator equal to ' } 1 \text { ' in year } t \text { marking the final year on the } \\
\text { engagement before the partner leaves short of the regular 5-year rotation cycle } \\
\text { (i.e., during years one through four of her tenure), and '0' otherwise. In some } \\
\text { analyses, we partition this variable into two groups: years before explainable non- } \\
\text { mandatory rotations (as indicated by the subscript expl) and all the other, } \\
\text { unexplained non-mandatory rotations (as indicated by the subscript unexpl). We } \\
\text { identify explainable rotations as years in which the partner either (i) drops from } \\
\text { the dataset after more than } 10 \text { years, (ii) has a title change to a higher position or } \\
\text { leadership role, (iii) switches location to a different office, (iv) leaves, but rotates } \\
\text { back after one or two years, or (v) fills in for one or two years for another partner } \\
\text { who subsequently rotates back. Data source: proprietary data submitted to the } \\
\text { PCAOB. }\end{array}$ \\
\hline $\begin{array}{l}\text { Year after Non-Mandatory } \\
\text { Rotation } \\
\text { (indicator) }\end{array}$ & $\begin{array}{l}\text { We set the binary indicator equal to ' } 1 \text { ' in year } t \text { marking the first year on the } \\
\text { engagement after the previous partner has left short of the regular } 5 \text {-year rotation } \\
\text { cycle (i.e., during years one through four of her tenure), and ' } 0 \text { ' otherwise. This } \\
\text { variable identifies a subset of Tenure Year } 1=1 \text { observations. Data source: } \\
\text { proprietary data submitted to the PCAOB. }\end{array}$ \\
\hline $\begin{array}{l}\text { Year before Audit Firm } \\
\text { Switch (indicator) }\end{array}$ & $\begin{array}{l}\text { We set the binary indicator equal to ' } 1 \text { ' in year } t \text { if the client firm switches its } \\
\text { audit firm in the next year. Data source: Audit Analytics. }\end{array}$ \\
\hline
\end{tabular}

Panel E: Client-specific Variables ${ }^{*}$

\begin{tabular}{|l|l|}
\hline Variable Name & Definition \\
\hline $\begin{array}{l}\text { Market Value } \\
\text { \$ million) }\end{array}$ & $\begin{array}{l}\text { Share price at fiscal year-end } t \text { (PRCC_F) multiplied by the number of total } \\
\text { shares outstanding (CSHO). }\end{array}$ \\
\hline Leverage (ratio) & $\begin{array}{l}\text { Total Long Term Debt (DLC + DLTT) / (Total Assets (AT) + Total Assets } t-1) / \\
2) .\end{array}$ \\
\hline
\end{tabular}




\begin{tabular}{|c|c|}
\hline Variable Name & Definition \\
\hline Return on Assets (ratio) & $\begin{array}{l}\text { Income before Extraordinary Items (IB) / ((Total Assets (AT) + Total Assets } t-1) / \\
\text { 2). }\end{array}$ \\
\hline $\begin{array}{l}\text { Loss Firm } \\
\text { (indicator) }\end{array}$ & $\begin{array}{l}\text { We set the binary indicator equal to ' } 1 \text { ' in year } t \text { if Income before Extraordinary } \\
\text { Items (IB) is negative, and ' } 0 \text { ' otherwise. }\end{array}$ \\
\hline $\begin{array}{l}\text { Cash Flow from Operations } \\
\text { (ratio) }\end{array}$ & $\begin{array}{l}\text { Cash Flows from Operations (OANCF) / ((Total Assets (AT) + Total Assetst } t \text { ) / } \\
\text { 2). }\end{array}$ \\
\hline $\begin{array}{l}\text { Book-to-Market } \\
\text { (ratio) }\end{array}$ & Total Common Equity (CEQ) / Market Value. \\
\hline \multirow[t]{3}{*}{ Altman Z-Score } & $\begin{array}{l}\text { Following Altman (1968) and Altman and Hotchkiss (2005, p. 246), we compute } \\
\text { the client's risk of bankruptcy in fiscal year } t \text { as: }\end{array}$ \\
\hline & $\begin{array}{l}0.717 \times(\text { Working Capital } / \text { Total Assets })+0.874 \times(\text { Retained Earnings } / \text { Total } \\
\text { Assets })+3.107 \times(\text { Operating Income } / \text { Total Assets })+0.420 \times(\text { Total Common } \\
\text { Equity / Total Liabilities })+0.998 \times(\text { Revenue } / \text { Total Assets })\end{array}$ \\
\hline & $\begin{array}{l}\text { with Working Capital }=(\mathrm{ACT}-\mathrm{LCT}), \text { Total Assets }=\mathrm{AT}, \text { Retained Earnings }= \\
\text { RE, Operating Income }=\text { OIADP, Total Common Equity }=\mathrm{CEQ}, \text { Total Liabilities } \\
=\mathrm{LT} \text {, and Revenue }=\text { REVT. Higher values indicate higher risk of bankruptcy. }\end{array}$ \\
\hline Sales Growth (\%) & ${\text { (Revenue (REVT) - Revenue } t-1) / \text { Revenue }_{t-1} .}$ \\
\hline $\begin{array}{l}\text { Cash Flow Volatility } \\
(\$ \text { million })\end{array}$ & $\begin{array}{l}\text { Standard deviation of Cash Flows from Operations (OANCF) over the four years } \\
t \text { to } t-3 \text {. We require at least three years of data for the computation of this variable. }\end{array}$ \\
\hline Receivables Turnover (ratio) & Revenue (REVT) / ((Total Receivables (RECT) + Total Receivables $t-1) / 2)$. \\
\hline Payables Turnover (ratio) & Cost of Goods Sold (COGS) / ((Total Payables (AP) + Total Payablest-1) / 2). \\
\hline Total Assets (\$ million) & Total Assets (AT) \\
\hline$P P \& E$ (\$ million) & Gross Property, Plant, and Equipment (PPEGT) \\
\hline $\begin{array}{l}\text { Restructuring Firm } \\
\text { (indicator) }\end{array}$ & $\begin{array}{l}\text { We set the binary indicator equal to ' } 1 \text { ' in year } t \text { if Discontinued Operations (DO) } \\
\text { or Restructuring Expense (RCP) is non-zero, and ' } 0 \text { ' otherwise. }\end{array}$ \\
\hline $\begin{array}{l}\text { M\&A Firm } \\
\text { (indicator) }\end{array}$ & $\begin{array}{l}\text { We set the binary indicator equal to ' } 1 \text { ' in year } t \text { if Acquisition Cash Flows } \\
\text { (AQC) is positive, and ' } 0 \text { ' otherwise. }\end{array}$ \\
\hline $\begin{array}{l}\text { Current Assets } \\
\text { (ratio) }\end{array}$ & Current Assets (ACT) / Total Assets (AT). \\
\hline $\begin{array}{l}\text { Reporting Lag } \\
\text { (days) }\end{array}$ & $\begin{array}{l}\text { Number of days between the end of the fiscal year } t \text { of client } i \text { and the date the } \\
\text { audit firm signs the audit opinion. Data source: Audit Analytics. }\end{array}$ \\
\hline $\begin{array}{l}\text { Business Segments } \\
\text { (number) }\end{array}$ & $\begin{array}{l}\text { Number of operating business segments as reported in the segment database. We } \\
\text { count the number of unique segment identifiers (SID) if the segment type is equal } \\
\text { to business segments (STYPE = "BUSSEG"). We assume a value of one if data is } \\
\text { missing. }\end{array}$ \\
\hline Foreign Sales $(\%)$ & $\begin{array}{l}\text { Foreign Sales / Total Sales (REVT). We determine Foreign Sales as the sum of } \\
\text { SALES if the segment type is geographic (STYPE = "GEOSEG") and the } \\
\text { geographic segment type is nondomestic (GEOTP = "3"). We assume a value of } \\
\text { zero if data is missing. }\end{array}$ \\
\hline
\end{tabular}

* All price and accounting data are from Compustat (we indicate Compustat variable names in parentheses). We measure the data at the end of fiscal year $t$ of client $i$, if not indicated otherwise. 


\section{APPENDIX B \\ Additional Analyses}

This appendix provides descriptive information and supplemental robustness analyses. In Section B1, we report the full model specification, including all the control variables, for several of the main analyses of the relation between engagement partner tenure and our proxies for audit quality and audit economics. In Section B2, we examine the relation between review partner tenure and audit effort. The review partner is also subject to the five-year limit, which raises the question of how her review hours vary over the tenure cycle. In Section B3, we detail the split into explainable and unexplained departures of the engagement partner before the end of the five-year tenure limit. We use this distinction in our main tests to assess differences in audit quality, fees, and hours between these two types of non-mandatory rotations. We also provide descriptive information on audit firms' rotation practices for their lead and review partners.

\section{B1. Tabulation of full models for audit quality, audit fees, and audit hours}

In the main body of the study, we only report coefficient estimates for Partner Tenure and a few select audit-specific variables in the tables. Yet, because many of the audit quality (e.g., PCAOB inspections) and audit process variables (e.g., partner hours) are not publicly available for a large sample of U.S. listed firms, we tabulate the full model, including all the controls, in Table B1. We limit the tabulation to the base specification for each outcome variable.

Panel A contains the full models for the relation between engagement partner tenure and audit quality. We tabulate coefficient estimates (and, in parenthesis, $t$-statistics or, in column 1, standard errors) for all six proxies of audit quality from Table 3. The Absolute Accruals model in the first column displays the highest number of significant correlations. Large, profitable firms with higher future growth prospects exhibit lower absolute accruals. Firms with higher and more volatile cash flows, lower bankruptcy risk, and greater realized growth in the past exhibit the 
opposite relation, as do firms that underwent a restructuring. These correlations are largely consistent with prior literature (e.g., Minutti-Meza, 2013). ${ }^{1}$ The likelihood of restating financial statements is higher for high growth firms (ex post and ex ante) with volatile cash flows and high leverage. Moreover, firms that incurred a loss, underwent a restructuring, or engaged in an M\&A transaction are also more likely to restate their financials. All these relations make intuitive sense. The announcement of restated financials is significantly correlated with only two of the client-specific control variables. Firms with more volatile cash flows are more likely to announce a restatement and, somewhat counterintuitive, after an M\&A transaction, firms are less likely to do so. An auditor is more likely to report a material control weakness for smaller, less profitable firms and after they have incurred a loss. We measure these relations conditional on the firm restating its financials in a subsequent period. Finally, in the last two columns, we find that high growth firms with higher bankruptcy risk are more likely to incur a PCAOB inspection finding, while the audit firm's internal inspection is more likely to produce a finding for small firms. Internal inspection findings are also negatively related to the loss firm indicator.

In Panel B, we tabulate the full specification for the Audit Fees regression (model 2 in Table 4, Panel A) and for the various audit effort outcome variables (models 1 to 3 in Table 5, Panel A). Many of the client-specific control variables are significant and exhibit the expected signs (see e.g., Ball, Jayaraman, Shivakumar, 2012). Larger firms that bear more risk (as shown by higher leverage ratios, the incurrence of a loss, or more volatile cash flows), with higher ex

\footnotetext{
1 While prior work, including Minutti-Meza (2013), generally uses discretionary accruals, we use total accruals given the econometric problems raised in Chen et al. (2017). However, comparing our associations with various control variables are similar to prior work. For instance, comparing our coefficient estimates to Table 3 from Minutti-Meza (2013), we find similar signs for Ln(Market Value), Return on Assets, Book-to-Market, Sales Growth, and Ln(Cash Flow Volatility). For other variables, we note Minutti-Meza (2013) does not find significant coefficients for Loss Firm, Cash Flow from Operations, and Altman Z-Score. Our coefficients differ for Return on Assets $_{t-1}$ and Leverage. Note that we do include financial firms in our analysis because we do not estimate a discretionary accruals model, plausibly reducing comparability. Additionally, we include an extensive set of fixed effects, notably client effects, to isolate changes from partner tenure and rotation.
} 
post and ex ante growth options and a more complex operating structure (i.e., higher number of business segments) are charged higher audit fees and require more audit effort in terms of total hours to complete the audit, total partner hours, and engagement partner hours. More profitable firms with higher cash flows from operations and a higher proportion of current assets display the opposite relation. Reporting Lag is positively correlated with the proxies for audit economics. This relation is likely endogenous because when auditors need more time, the signing of the audit opinion is delayed.

In Panel C, we focus on Billing Realization. This measure reflects the profitability of the engagement. Audit firms calculate billing realization as the actual audit fees charged to the client divided by the "sticker price." The latter equals the total hours performed by all staff and partners multiplied by the respective billing rates. Importantly, the fee regressions combined with the audit hour results does not necessarily yield the same inferences as the analysis of billing realization. It is plausible that audit firms take actions to maintain consistent audit profitability amid changing hours and fees over the tenure cycle. For instance, an audit firm could substitute lower ranked audit staff into client service when that client negotiates lower audit fees. Similarly, audit firms could reallocate work away from senior managers and managers (i.e. higher ranks) to seniors and associates (i.e. lower ranks) when a client requires additional audit hours. In those cases, one could observe lower fees and/or higher hours, but no changes in audit profitability.

As the results in Panel C show, Billing Realization is positively related to partner tenure, suggesting that profitability increases over time. This result is consistent with higher fees and lower audit hours in the later years of the partner cycle (see Tables 4 and 5) and similar to findings in Bedard and Johnstone (2010) for planned audit effort and planned billing realization. Audit firms display lower billing realization for risky clients, as measured by the Client Risk 
Rating variable. Most of the client-specific control variables are insignificant. In column (1), only the coefficients on size, book-to-market, current assets, and the number of business segments significantly load. Yet, the explanatory power of the model is high (R-squared of 91 percent). In column (2), we replace the general year fixed effects with specific year fixed effects for each audit firm. Audit firms use different bill rates, that is, different denominators, by year, which are accounted for by this specification. The coefficient on Partner Tenure is only slightly attenuated by the inclusion of the additional fixed effects and the inferences remain the same.

\section{B2. Analysis of review partner tenure and rotation}

The review partner is a second partner involved in the audit engagement whose tenure is also limited to a five-year term. In Table B2, we focus on how the review partner's tenure cycle is related to total Audit Hours, the Review Partner Hours, and the Engagement Partner Hours. In the first two columns, we show that review partner tenure is negatively related to the total audit hours spent on the engagement and to the hours the review partner herself spends reviewing the engagement. These correlations are not driven by the lead partner whose tenure we include as a control in the model. Moreover, the two partners show little response to the tenure of each other. While the coefficient on Partner Tenure is slightly negative in explaining the hours of the review partner (mainly driven by a positive year one effect; not tabulated), the coefficient on Review Partner Tenure is insignificant in explaining the hours of the engagement partner (column 3). At the same time, the coefficient on Partner Tenure is essentially the same in terms of magnitude and significance as in the main specification in Table 5, Panel A.

The year-by-year analyses (columns 4 to 6) indicate that the entire audit staff spends fewer hours on the client in the final years of the review partner's tenure cycle. For her own hours, the review partner spends more time in the initial two years of the transition, but scales 
back her involvement substantially towards the end. Finally, we find that the lead partner spends slightly fewer hours on the engagement during the first year of the review partner, but there is no effect on Engagement Partner Hours during the other years of the review partner's tenure cycle.

\section{B3. Further evidence on non-mandatory partner rotations}

In our main tests, we split the departures of the engagement partner before the end of the five-year tenure limit into explainable and unexplained departures to assess differences in audit quality, fees, and hours between these two types of non-mandatory rotations (see Table 8). In this section, we (i) validate the frequent occurrence of non-mandatory rotations in our sample using an alternative data source, (ii) outline how we construct the explainable and unexplained rotation variables, and (iii) provide further descriptive information on audit firms' rotation practices regarding their lead and review partners.

\section{B3.1. Validating the relatively high frequency of non-mandatory rotations}

The PCAOB collects information specific to audits selected for inspection. The audit firm provides this information in the so-called "engagement profile" shortly before an inspection takes place. Among other things (e.g., data on audit materiality; see Choudhary, Merkley, and Schipper, 2017), the engagement profile contains all the partners' tenure information, and the lead partner signs the form to confirm that the data is correct. We use this alternative data source to gauge the observed frequency of non-mandatory rotations in our sample. Specifically, for client firms with more than one PCAOB inspection over the period 2006 to 2015, we can construct a partner tenure sequence following a hypothetical five-year rotation cycle and compare it to the actual partner tenure cycle reported in the subsequent engagement profiles. For instance, if the lead partner in 2006 (year of the first inspection) is in her second year of tenure, 
then the lead partner in 2012 (year of the second inspection) should be in year three. In case of discrepancies, we assume that a non-mandatory rotation has occurred at this client in the interim.

Using this approach, we show in Panel A of Table B3 that out of the more than 500 clients with multiple PCAOB inspections over the years 2006 to 2015, 51 percent must have had at least one non-mandatory rotation. For 49 percent of the clients with multiple inspections, we can fully account for the partner rotations based on the five-year term. The proportion of nonmandatory rotations that we draw from the PCAOB engagement profile data is larger than the 31 percent of clients with non-mandatory rotations in our sample. This finding could reflect the selection criteria for PCAOB inspections (and, hence, limits the generalizability of engagement profile data). Importantly, however, this benchmark using a different data source is larger than the ratio of non-mandatory rotations that we observe in our main analyses, which provides comfort that the (high) ratio of non-mandatory rotations in the main analysis is not an aberration.

\section{B3.2. Distinction between explainable and unexplained non-mandatory rotations}

In some of our tests, we distinguish between explainable and unexplained non-mandatory rotations. Explainable rotations are within-firm partner switches before the five-year limit due to reasons such as retirement, promotion, dislocation, sabbatical, maternity leave, temporary illness, etc. We identify explainable non-mandatory rotations based on the following data characteristics: First, because we do not observe a partner's age, we flag partners with at least 10 years of

experience that disappear from our data as potential retirements. Second, we proxy for a partner's promotion by the title information in the engagement profile. Partners with no title in the year of the non-mandatory switch, and a newly assigned title or leadership role (e.g., Office Managing Partner) in the first year on the new engagement fall into this category. Third, we count any change in the signing partner's office affiliation as a relocation to a different city. 
Finally, we flag partners that rotate off a client for one or two years and later return to the same client as well as their temporary replacements. These interrupted tenure cycles are less likely to be driven by dissonances in the client-partner relationship and/or quality issues (an assertion that is testable and supported by our results for explainable rotations in Table 8).

Panel B of Table B3 shows that out of the 1,467 non-mandatory rotations in our sample, 379 (26 percent) seem to be explainable by the above reasons. This fraction is likely a conservative estimate. The remaining 1,088 are left unexplained. For comparison, we also provide frequency counts for the tenure of incumbent partners in the year of an audit firm switch in Panel C. In the majority of cases, the audit firm switch occurs before the end of the five-year term (and, in that sense, also represents an early termination). However, we do not include audit firm switches before the end of the tenure term in the count of non-mandatory rotations. Thus, our numbers for non-mandatory rotations hold the client-audit firm relation fixed.

\section{B3.3. Details on audit firms' rotation practices for engagement and review partners}

In this subsection, we discuss in more detail rotation practices that audit firms could use to reduce the disruption for the client, for instance, by rotating partners back to the same client or alternating assignments between lead and review partners. We also discuss how such practices, if prevalent, could affect some of our results.

Technically, an audit firm can return a partner to the same client after a five-year coolingoff period (17 C.F.R. $§ ~ 210.2-01(c)(6)$ and SEC 33-8183). Our data series covers seven years. Thus, we can only observe such instances if a partner audits the client in 2008, departs in 2009, and returns to the same client for the 2014 audit. We find 46 such cases out of the 658 withinfirm (mandatory and non-mandatory) rotations in 2008 (see Table 1, Panel B). This 7-percent rate seems low if there were substantial benefits to relationship continuity from partner returns. 
An audit firm might rotate a partner off after fewer than five years to avoid the five-year cooling-off period. ${ }^{2}$ We observe 22 cases in which a partner returns to the same client with a cooling-off period of less than five years. In 16 cases, the cooling-off period was one year; however, the audit firms appear to count these off years "as if" the partner remained on the client for tenure limit purposes. ${ }^{3}$ As an example, in one case the lead partner rotates off after three years, is replaced by the review partner for a single year, and then returns to the engagement as lead partner for another year or two. Overall, the incidence of such cases is rare, implying that the number of non-mandatory within-firm rotations in Tables 1 and 8 are unlikely to be inflated by abbreviated tenure cycles to avoid the five-year cooling-off period.

Finally, an audit firm could use a review partner assignment to prepare a partner for the lead position or, conversely, the audit firm could rotate a former lead partner into the review partner position to monitor and support the new incoming lead partner. Years in either position account towards the combined five-year limit. ${ }^{4}$ Potential other reasons for these role reversals include client incentives to ensure consistency or temporal unavailability of the lead partner (e.g., due to maternity/paternity leave, illness, sabbatical, or career development) that requires the audit firm to ask the review partner to substitute during the absence. These types of role switches could affect our analyses in two ways. First, the switches could add noise to how we measure non-mandatory rotations. A partner who switches roles ends up with a shorter than five-year tenure as lead or review partner. If we are unable to observe the reversal of roles, we will classify

2 The rule, 17 C.F.R. $§ 210.2-01$ (c)(6), states, "An accountant is not independent of an audit client when any audit partner within the five consecutive year period following the performance of services [for five consecutive years as lead or concurring partner] performs for that audit client the services of a lead [...] or concurring partner." Simply, if a partner is lead or review for five years, the cool off must last five years. If a partner is lead or review for less than five years, she has to cool off for at least one year and then can return to the client as lead or review.

${ }^{3}$ For instance, we observe no cases in which the sum of the years before the cool off, the year of the cool off, and the years after the cool off on the same client exceeds the limit of five years.

4 The rule, 17 C.F.R. $\S 210.2-01(\mathrm{c})(6)$, states, "An accountant is not independent of an audit client when any audit partner $[\ldots]$ performs the services of a lead $[\ldots]$ or concurring partner $[\ldots]$ for more than five consecutive years" (emphasis added). 
the switch as (unexplained) non-mandatory rotation. Additionally, the years spent in the new role will also be less than five but likely mark the end of the term limit and, hence, should be classified as a mandatory rotation. Second, the switching of roles, if unrecognized, could lead us to classify the audit team as new while effectively the same audit team stays in place. We count 164 lead partners who at any time over our sample period also serve as review partners on 159 clients. The typical sequence is to start out as review partner before assuming a lead role (i.e., 157 cases). The 164 partners give rise to 596 client-year observations in which the partner serves either as lead or review partner at the same client. In 45 cases, the consecutive time spent as review or lead partner reaches the five-year limit. ${ }^{6}$ We try to carefully account for these facts when we construct our variables. ${ }^{7}$

${ }^{6}$ Due to the short time series, we are unable to determine in all cases if a partner serving both as lead and review partner completes her five years. Out of the 64 partners who switch roles and for whom we can observe the entire tenure cycle (i.e., partners beginning in 2009 or 2010), only 29, or 45 percent, complete the five-year cycle. We exclude partners beginning in 2008 from this count because we are often unable to determine how long they have served a client prior to that year.

7 When coding the variables Year before Non-Mandatory Rotation and Year after Non-Mandatory Rotation, we set them equal to ' 0 ' whenever we observe the exiting partner's five-year cycle in both the lead and review roles or if the partner began as review partner in 2008 or earlier. For coding Audit Team Rotation Cycle, we set this variable to ' 0 ' over the full cycle whenever we observe that the partners switch roles from the prior year. 
TABLE B1

Engagement Partner Tenure and Audit Quality/Audit Economics - Tabulation of Full Models

Panel A: Audit Quality (Table 3)

\begin{tabular}{|c|c|c|c|c|c|c|}
\hline Dependent Variables: & $\begin{array}{l}(1) \\
\text { Absolute } \\
\text { Accruals } \\
(\times 100)\end{array}$ & $\begin{array}{c}\text { (2) } \\
\text { Restated } \\
\text { Financials }\end{array}$ & $\begin{array}{l}\text { (3) } \\
\text { Announced } \\
\text { Restate- } \\
\text { ments }\end{array}$ & $\begin{array}{c}\text { (4) } \\
404 b \\
\text { Opinion } \\
\text { with } M C W\end{array}$ & $\begin{array}{l}\text { (5) } \\
\text { PCAOB } \\
\text { Inspection } \\
\text { Finding }\end{array}$ & $\begin{array}{l}\text { (6) } \\
\text { Audit Firm } \\
\text { Inspection } \\
\text { Finding }\end{array}$ \\
\hline \multicolumn{7}{|l|}{ Audit-specific Variables: } \\
\hline Partner Tenure & $\begin{array}{l}-0.021 \\
(0.032)\end{array}$ & $\begin{array}{l}-0.001 \\
(-0.81)\end{array}$ & $\begin{array}{l}-0.005^{* * * *} \\
(-3.46)\end{array}$ & $\begin{array}{l}-0.003 \\
(-0.67)\end{array}$ & $\begin{array}{r}0.006 \\
(0.69)\end{array}$ & $\begin{array}{r}0.001 \\
(0.08)\end{array}$ \\
\hline Client Risk Rating & $\begin{array}{l}-0.271 * * \\
(0.109)\end{array}$ & $\begin{array}{l}-0.005 \\
(-0.71)\end{array}$ & $\begin{array}{l}-0.007 \\
(-1.50)\end{array}$ & $\begin{array}{l}0.017 * \\
(1.95)\end{array}$ & $\begin{array}{r}0.016 \\
(0.79)\end{array}$ & $\begin{array}{l}-0.002 \\
(-0.11)\end{array}$ \\
\hline $\begin{array}{l}\text { Client-specific Controls: } \\
\text { Ln(Market Value })\end{array}$ & $\begin{array}{l}-0.421 * * \\
(0.203)\end{array}$ & $\begin{array}{r}0.013 \\
(1.53)\end{array}$ & $\begin{array}{l}-0.002 \\
(-0.37)\end{array}$ & $\begin{array}{l}-0.028 * * * \\
(-4.02)\end{array}$ & $\begin{array}{l}-0.006 \\
(-0.41)\end{array}$ & $\begin{array}{l}-0.032 * * * \\
(-3.08)\end{array}$ \\
\hline Leverage & $\begin{array}{c}0.427 \\
(0.869)\end{array}$ & $\begin{array}{l}0.068 * \\
(1.70)\end{array}$ & $\begin{array}{r}0.017 \\
(0.72)\end{array}$ & $\begin{array}{l}-0.043 \\
(-1.62)\end{array}$ & $\begin{array}{r}0.002 \\
(0.04)\end{array}$ & $\begin{array}{r}0.051 \\
(1.04)\end{array}$ \\
\hline Return on Assets & $\begin{array}{l}-60.12 * * * \\
(2.687)\end{array}$ & $\begin{array}{l}-0.014 \\
(-0.27)\end{array}$ & $\begin{array}{l}-0.005 \\
(-0.16)\end{array}$ & $\begin{array}{l}-0.168 * \\
(-1.88)\end{array}$ & $\begin{array}{c}0.104 \\
(0.50)\end{array}$ & $\begin{array}{l}-0.051 \\
(-0.31)\end{array}$ \\
\hline Return on Assetst-1 & $\begin{array}{l}-1.560^{*} \\
(0.924)\end{array}$ & $\begin{array}{l}-0.030 \\
(-1.00)\end{array}$ & $\begin{array}{r}0.001 \\
(0.05)\end{array}$ & $\begin{array}{c}0.055 \\
(0.77)\end{array}$ & $\begin{array}{c}0.183 \\
(1.42)\end{array}$ & $\begin{array}{c}0.140 \\
(1.46)\end{array}$ \\
\hline Loss Firm & $\begin{array}{c}0.131 \\
(0.292)\end{array}$ & $\begin{array}{l}0.028 * * * \\
(2.73)\end{array}$ & $\begin{array}{c}0.000 \\
(0.01)\end{array}$ & $\begin{array}{l}0.042 * * \\
(2.28)\end{array}$ & $\begin{array}{c}-0.035 \\
(-0.95)\end{array}$ & $\begin{array}{l}-0.056^{*} \\
(-1.81)\end{array}$ \\
\hline Cash Flow from Operations & $\begin{array}{l}39.98 * * * \\
(2.648)\end{array}$ & $\begin{array}{l}-0.091^{*} \\
(-1.78)\end{array}$ & $\begin{array}{c}-0.047 \\
(-1.33)\end{array}$ & $\begin{array}{c}0.128 \\
(1.59)\end{array}$ & $\begin{array}{c}-0.321 \\
(-1.55)\end{array}$ & $\begin{array}{c}0.059 \\
(0.38)\end{array}$ \\
\hline Book-to-Market & $\begin{array}{l}-0.419 * * \\
(0.198)\end{array}$ & $\begin{array}{l}0.015^{*} \\
(1.70)\end{array}$ & $\begin{array}{c}0.006 \\
(1.14)\end{array}$ & $\begin{array}{c}-0.013 \\
(-1.33)\end{array}$ & $\begin{array}{l}0.078 * * * \\
(4.39)\end{array}$ & $\begin{array}{c}0.015 \\
(0.72)\end{array}$ \\
\hline Altman Z-Score & $\begin{array}{l}0.540 * * * \\
(0.162)\end{array}$ & $\begin{array}{c}0.003 \\
(0.72)\end{array}$ & $\begin{array}{c}-0.002 \\
(-0.62)\end{array}$ & $\begin{array}{c}-0.000 \\
(-0.05)\end{array}$ & $\begin{array}{l}-0.022 * * \\
(-2.18)\end{array}$ & $\begin{array}{c}-0.004 \\
(-0.47)\end{array}$ \\
\hline Sales Growth & $\begin{array}{l}1.281 * * * \\
(0.489)\end{array}$ & $\begin{array}{l}0.018 * * \\
(2.04)\end{array}$ & $\begin{array}{c}0.003 \\
(0.53)\end{array}$ & $\begin{array}{c}0.003 \\
(0.15)\end{array}$ & $\begin{array}{c}-0.031 \\
(-0.81)\end{array}$ & $\begin{array}{c}-0.019 \\
(-0.64)\end{array}$ \\
\hline Ln(Cash Flow Volatility) & $\begin{array}{l}0.445^{* * * *} \\
(0.102)\end{array}$ & $\begin{array}{l}0.020^{* * * *} \\
(3.17)\end{array}$ & $\begin{array}{l}0.010^{* * *} \\
(2.57)\end{array}$ & $\begin{array}{c}0.008 \\
(1.20)\end{array}$ & $\begin{array}{c}-0.003 \\
(-0.26)\end{array}$ & $\begin{array}{c}0.003 \\
(0.30)\end{array}$ \\
\hline Restructuring Firm & $\begin{array}{l}2.734 * * * \\
(0.391)\end{array}$ & $\begin{array}{l}0.029 * * \\
(2.10)\end{array}$ & $\begin{array}{c}0.017 \\
(1.43)\end{array}$ & $\begin{array}{r}0.045 \\
(1.41)\end{array}$ & $\begin{array}{c}-0.024 \\
(-0.39)\end{array}$ & $\begin{array}{c}-0.015 \\
(-0.35)\end{array}$ \\
\hline M\&A Firm & $\begin{array}{l}-0.089 \\
(0.116)\end{array}$ & $\begin{array}{c}0.014 * \\
(1.82)\end{array}$ & $\begin{array}{l}-0.014 * * \\
(-2.44)\end{array}$ & $\begin{array}{c}-0.005 \\
(-0.42)\end{array}$ & $\begin{array}{c}0.031 \\
(1.29)\end{array}$ & $\begin{array}{c}0.001 \\
(0.06)\end{array}$ \\
\hline Absolute Accruals & - & $\begin{array}{c}0.044 \\
(0.90)\end{array}$ & $\begin{array}{c}0.020 \\
(0.56)\end{array}$ & $\begin{array}{c}-0.102 \\
(-1.21)\end{array}$ & $\begin{array}{c}0.032 \\
(0.14)\end{array}$ & $\begin{array}{c}-0.185 \\
(-1.08)\end{array}$ \\
\hline Receivables Turnover $\mathrm{t}-1$ & $\begin{array}{l}-0.000 \\
(0.008)\end{array}$ & - & - & - & - & - \\
\hline Payables Turnover ${ }_{\mathrm{t}-1}$ & $\begin{array}{l}0.026 * * \\
(0.013)\end{array}$ & - & - & - & - & - \\
\hline $\begin{array}{l}\text { Jones Model Regressors } \\
\text { Fixed Effects: }\end{array}$ & Yes & No & No & No & No & No \\
\hline $\begin{array}{l}\text { Client }(\mathrm{C}) \text { or Audit Firm (A) } \\
\text { Year (Y) } \\
\text { Audit Firm Tenure (AT) } \\
\text { Industry-Perf. Decile (ID) }\end{array}$ & $\begin{array}{l}\mathrm{C} \\
\mathrm{Y} \\
\mathrm{AT} \\
\mathrm{ID}\end{array}$ & $\begin{array}{c}\mathrm{C} \\
\mathrm{Y} \\
\mathrm{AT}\end{array}$ & $\begin{array}{c}\mathrm{C} \\
\mathrm{Y} \\
\mathrm{AT}\end{array}$ & $\begin{array}{c}\mathrm{A} \times \mathrm{Y} \\
\mathrm{AT}\end{array}$ & $\begin{array}{l}\mathrm{A} \times \mathrm{Y} \\
\mathrm{AT}\end{array}$ & $\begin{array}{l}\mathrm{A} \times \mathrm{Y} \\
\mathrm{AT}\end{array}$ \\
\hline $\begin{array}{l}\text { R-squared } \\
\text { Observations }\end{array}$ & $\begin{array}{c}0.762 \\
16,956\end{array}$ & $\begin{array}{c}0.501 \\
17,660\end{array}$ & $\begin{array}{c}0.221 \\
17,653\end{array}$ & $\begin{array}{l}0.092 \\
2,903\end{array}$ & $\begin{array}{l}0.139 \\
1,560\end{array}$ & $\begin{array}{l}0.225 \\
1,801\end{array}$ \\
\hline
\end{tabular}


TABLE B1-Continued

Panel B: Audit Fees (Table 4, Panel A) and Audit Hours (Table 5, Panel A)

\begin{tabular}{|c|c|c|c|c|}
\hline & (1) & (2) & (3) & (4) \\
\hline Dependent Variables: & $\begin{array}{l}\mathrm{Ln}(\text { Audit } \\
\text { Fees })\end{array}$ & $\begin{array}{c}\mathrm{Ln}(\text { Audit } \\
\text { Hours })\end{array}$ & $\begin{array}{c}\mathrm{Ln}(\text { Total } \\
\text { Partner Hours })\end{array}$ & $\begin{array}{c}\text { Ln(Engage- } \\
\text { ment Partner } \\
\text { Hours })\end{array}$ \\
\hline \multicolumn{5}{|l|}{ Audit-specific Variables: } \\
\hline Partner Tenure & $\begin{array}{l}0.006^{* * * *} \\
(5.73)\end{array}$ & $\begin{array}{l}-0.006 * * * \\
(-4.46)\end{array}$ & $\begin{array}{l}-0.004 \\
(-1.34)\end{array}$ & $\begin{array}{l}-0.043^{* * *} \\
(-11.41)\end{array}$ \\
\hline Client Risk Rating & $\begin{array}{c}0.000 \\
(0.10)\end{array}$ & $\begin{array}{l}0.033 * * * \\
(5.77)\end{array}$ & $\begin{array}{c}0.002 \\
(0.26)\end{array}$ & $\begin{array}{c}0.011 \\
(0.71)\end{array}$ \\
\hline Ln(Audit Hours) & $\begin{array}{l}0.404 * * * \\
(20.68)\end{array}$ & - & - & - \\
\hline \multicolumn{5}{|l|}{ Client-specific Controls: } \\
\hline Ln(Market Value) & $\begin{array}{l}0.077 * * * \\
(11.853)\end{array}$ & $\begin{array}{l}0.082^{* * * *} \\
(9.42)\end{array}$ & $\begin{array}{l}0.046^{* * * *} \\
(3.36)\end{array}$ & $\begin{array}{l}0.094 * * * \\
(5.23)\end{array}$ \\
\hline Leverage & $\begin{array}{l}0.242 * * * \\
(8.446)\end{array}$ & $\begin{array}{l}0.274 * * * \\
(7.65)\end{array}$ & $\begin{array}{l}0.244 * * * \\
(3.71)\end{array}$ & $\begin{array}{l}0.326 * * * \\
(4.94)\end{array}$ \\
\hline Return on Assets & $\begin{array}{l}-0.120 * * * \\
(-3.528)\end{array}$ & $\begin{array}{l}-0.112 * * * \\
(-2.74)\end{array}$ & $\begin{array}{l}-0.051 \\
(-0.63)\end{array}$ & $\begin{array}{l}-0.114 \\
(-1.29)\end{array}$ \\
\hline Return on Assets $t_{t-1}$ & $\begin{array}{c}0.003 \\
(0.171)\end{array}$ & $\begin{array}{l}-0.020 \\
(-0.80)\end{array}$ & $\begin{array}{c}0.002 \\
(0.05)\end{array}$ & $\begin{array}{c}0.008 \\
(0.12)\end{array}$ \\
\hline Loss Firm & $\begin{array}{l}0.019 * * * \\
(2.987)\end{array}$ & $\begin{array}{l}0.034 * * * \\
(4.08)\end{array}$ & $\begin{array}{c}0.024 \\
(1.61)\end{array}$ & $\begin{array}{c}0.013 \\
(0.65)\end{array}$ \\
\hline Cash Flow from Operations & $\begin{array}{l}-0.080 * * \\
(-2.362)\end{array}$ & $\begin{array}{c}-0.071 \\
(-1.61)\end{array}$ & $\begin{array}{c}-0.098 \\
(-1.27)\end{array}$ & $\begin{array}{l}-0.132 \\
(-1.50)\end{array}$ \\
\hline Book-to-Market & $\begin{array}{l}0.044 * * * \\
(5.991)\end{array}$ & $\begin{array}{l}0.033^{* * * *} \\
(2.81)\end{array}$ & $\begin{array}{c}0.019 \\
(1.20)\end{array}$ & $\begin{array}{l}0.073 * * * \\
(3.41)\end{array}$ \\
\hline Altman Z-Score & $\begin{array}{c}0.005 \\
(1.326)\end{array}$ & $\begin{array}{l}0.003 \\
(0.62)\end{array}$ & $\begin{array}{l}0.006 \\
(0.73)\end{array}$ & $\begin{array}{c}0.003 \\
(0.38)\end{array}$ \\
\hline Sales Growth & $\begin{array}{c}0.014 * \\
(1.947)\end{array}$ & $\begin{array}{l}0.026 * * \\
(2.50)\end{array}$ & $\begin{array}{l}0.040 * * \\
(2.18)\end{array}$ & $\begin{array}{l}0.015 \\
(0.77)\end{array}$ \\
\hline Ln(Cash Flow Volatility) & $\begin{array}{l}0.025^{* * * *} \\
(6.451)\end{array}$ & $\begin{array}{l}0.041^{* * * *} \\
(7.34)\end{array}$ & $\begin{array}{l}0.023 * * \\
(2.35)\end{array}$ & $\begin{array}{l}-0.015 \\
(-1.32)\end{array}$ \\
\hline Absolute Accruals & $\begin{array}{c}0.055 \\
(1.624)\end{array}$ & $\begin{array}{l}0.082 * \\
(1.95)\end{array}$ & $\begin{array}{l}0.153 * * \\
(2.00)\end{array}$ & $\begin{array}{c}0.052 \\
(0.58)\end{array}$ \\
\hline Current Assets & $\begin{array}{l}-0.217 * * * \\
(-6.334)\end{array}$ & $\begin{array}{l}-0.379 * * * \\
(-9.08)\end{array}$ & $\begin{array}{l}-0.291 * * * \\
(-3.91)\end{array}$ & $\begin{array}{l}-0.328 * * * \\
(-3.58)\end{array}$ \\
\hline Reporting Lag & $\begin{array}{l}0.003 * * * \\
(7.297)\end{array}$ & $\begin{array}{l}0.005^{* * * *} \\
(8.85)\end{array}$ & $\begin{array}{l}0.005^{* * * *} \\
(6.26)\end{array}$ & $\begin{array}{l}0.007 * * * \\
(7.48)\end{array}$ \\
\hline Business Segments & $\begin{array}{l}0.020 * * * \\
(4.938)\end{array}$ & $\begin{array}{l}0.029 * * * \\
(4.54)\end{array}$ & $\begin{array}{c}0.008 \\
(0.56)\end{array}$ & $\begin{array}{c}0.006 \\
(0.56)\end{array}$ \\
\hline Foreign Sales & $\begin{array}{l}0.150 * * * \\
(3.631)\end{array}$ & $\begin{array}{l}0.059 \\
(0.94)\end{array}$ & $\begin{array}{c}0.015 \\
(0.16)\end{array}$ & $\begin{array}{c}0.171 \\
(1.41)\end{array}$ \\
\hline $\begin{array}{l}\text { Fixed Effects: } \\
\text { Client (C) } \\
\text { Year (Y) } \\
\text { Audit Firm Tenure (AT) }\end{array}$ & $\begin{array}{l}\mathrm{C} \\
\mathrm{Y} \\
\mathrm{AT}\end{array}$ & $\begin{array}{l}\mathrm{C} \\
\mathrm{Y} \\
\mathrm{AT}\end{array}$ & $\begin{array}{l}\mathrm{C} \\
\mathrm{Y} \\
\mathrm{AT}\end{array}$ & $\begin{array}{c}\mathrm{C} \\
\mathrm{Y} \\
\mathrm{AT}\end{array}$ \\
\hline $\begin{array}{l}\text { R-squared } \\
\text { Observations }\end{array}$ & $\begin{array}{c}0.978 \\
17,518\end{array}$ & $\begin{array}{c}0.944 \\
17,568\end{array}$ & $\begin{array}{c}0.915 \\
10,148\end{array}$ & $\begin{array}{l}0.888 \\
7,145\end{array}$ \\
\hline
\end{tabular}


Panel C: Billing Realization

Dependent Variable:

Audit-specific Variables:

Partner Tenure

Client Risk Rating

Ln(Audit Hours)

Client-specific Controls:

Ln(Market Value)

Leverage

Return on Assets

Return on Assetst -1

Loss Firm

Cash Flow from Operations

Book-to-Market

Altman Z-Score

Sales Growth

$\operatorname{Ln}($ Cash Flow Volatility)

Absolute Accruals

Current Assets

Reporting Lag

Business Segments

Foreign Sales

Fixed Effects:

Client (C) or Audit Firm (A)

Year (Y)

Audit Firm Tenure (AT)

R-squared

Observations
(1)

(2)

Billing Realization

$\begin{array}{ll}0.414^{* * *} & 0.386^{* * *} \\ (9.58) & (9.92) \\ -0.316^{*} & -0.377^{* *} \\ (-1.73) & (-2.43) \\ -8.345^{* * *} & -5.722^{* * *} \\ (-10.55) & (-8.08)\end{array}$

$1.152 * * *$

(5.88)

(5.22)

$1.909^{* *}$

(2.21)

$-2.052^{* *}$

(-2.02)

$-1.067$

$(-1.55)$

0.084

(0.39)

1.504

(1.41)

0.420 *

(1.65)

0.155

(1.41)

-0.491 **

$(-2.38)$

0.050

(0.39)

$-0.395$

$(-0.35)$

$-1.756^{*}$

$(-1.72)$

$0.034^{* * * *}$

(3.09)

$0.338 * * *$

(3.09)

$-1.250$

$(-0.96)$

$(-0.26)$

C

$\mathrm{A} \times \mathrm{Y}$

AT

AT

0.906

0.930

17,549

(Continued) 
TABLE B1-Continued

The table reports analyses of the relation between engagement partner tenure and several measures of audit quality (Panel A) and audit economics (Panel B). We measure audit quality for client $i$ in year $t$ using various assessments of a client's reporting process (e.g., whether the auditor issues a $404 b$ Opinion with MCW regarding the client's internal controls) and the outcomes of audit-level inspections by the PCAOB or the audit firm. Our proxies for audit economics are audit fees and audit/partner hours. In Panel C, we use Billing Realization as the dependent variable. Our variable of interest, Partner Tenure, reflects the number of consecutive years that the audit partner manages the engagement, and ranges from 1 to 5. For Panel A, column 1, we multiply Absolute Accruals by 100 because the estimated coefficients are so small and include the Jones (1991) model regressors as controls (i.e., the inverse of Total Assets, Sales Growth, and $P P \& E$ over total assets). We also report robust standard errors instead of $t$-statistics in this column. We include (but do not report) fixed effects for individual clients (C) or audit firms (A), fiscal years (Y), the number of consecutive years the client is with the same audit firm (Audit Firm Tenure, AT), or a client's industry decile rank based on its Return on Assets (Industry-Performance Decile, ID) as indicated. For all variable definitions, see Appendix A. Ln stands for the natural log of the raw values and $t-1$ indicates values lagged by one year. The table reports OLS coefficient estimates and (in parentheses) $t$-statistics based on robust standard errors clustered by firm. $* * *, * *$, and $*$ indicate statistical significance at the $1 \%, 5 \%$, and $10 \%$ levels (two-tailed). 
TABLE B2

Review Partner Tenure and Audit Hours

\begin{tabular}{|c|c|c|c|c|c|c|}
\hline Dependent Variables: & $\begin{array}{c}(1) \\
\operatorname{Ln}(\text { Audit } \\
\text { Hours })\end{array}$ & $\begin{array}{c}\text { (2) } \\
\text { Ln(Review } \\
\text { Partner Hours })\end{array}$ & $\begin{array}{c}\text { (3) } \\
\text { Ln(Engagement } \\
\text { Partner Hours })\end{array}$ & $\begin{array}{c}(4) \\
\text { Ln(Audit } \\
\text { Hours })\end{array}$ & $\begin{array}{c}(5) \\
\text { Ln(Review } \\
\text { Partner Hours })\end{array}$ & $\begin{array}{c}(6) \\
\text { Ln(Engagement } \\
\text { Partner Hours })\end{array}$ \\
\hline \multicolumn{7}{|l|}{ Audit-specific Variables: } \\
\hline Partner Tenure & $\begin{array}{l}-0.006 * * * \\
(-4.40)\end{array}$ & $\begin{array}{l}-0.005^{*} \\
(-1.89)\end{array}$ & $\begin{array}{l}-0.043^{* * *} \\
(-11.46)\end{array}$ & $\begin{array}{l}-0.006 \text { *** } \\
(-4.41)\end{array}$ & $\begin{array}{l}-0.005^{*} \\
(1.92)\end{array}$ & $\begin{array}{l}-0.043^{* * *} \\
(-11.48)\end{array}$ \\
\hline Review Partner (RP) Tenure & $\begin{array}{l}-0.004 * * * \\
(-2.74)\end{array}$ & $\begin{array}{l}-0.026^{* * * *} \\
(-8.99)\end{array}$ & $\begin{array}{r}0.003 \\
(0.91)\end{array}$ & - & - & - \\
\hline RP Tenure Year 1 & - & - & - & $\begin{array}{c}0.004 \\
(0.73)\end{array}$ & $\begin{array}{l}0.044 * * * \\
(4.66)\end{array}$ & $\begin{array}{l}-0.022 * \\
(1.75)\end{array}$ \\
\hline RP Tenure Year 2 & - & - & - & $\begin{array}{l}0.000 \\
(0.07)\end{array}$ & $\begin{array}{l}0.017 * * \\
(1.98)\end{array}$ & $\begin{array}{l}-0.017 \\
(-1.54)\end{array}$ \\
\hline RP Tenure Year 3 (baseline) & - & - & - & - & - & - \\
\hline RP Tenure Year 4 & - & - & - & $\begin{array}{l}-0.010^{*} \\
(-1.90)\end{array}$ & $\begin{array}{l}-0.012 \\
(-1.28)\end{array}$ & $\begin{array}{c}-0.008 \\
(-0.61)\end{array}$ \\
\hline RP Tenure Year 5 & - & - & - & $\begin{array}{l}-0.013^{*} \\
(-1.96)\end{array}$ & $\begin{array}{l}-0.078 * * * \\
(-5.97)\end{array}$ & $\begin{array}{l}-0.016 \\
(-1.06)\end{array}$ \\
\hline Client Risk Rating & $\begin{array}{l}0.033 * * * \\
(5.77)\end{array}$ & $\begin{array}{l}0.043 * * * \\
(4.69)\end{array}$ & $\begin{array}{c}0.012 \\
(0.76)\end{array}$ & $\begin{array}{l}0.033 * * * \\
(5.76)\end{array}$ & $\begin{array}{l}0.043^{* * * *} \\
(4.66)\end{array}$ & $\begin{array}{l}0.012 \\
(0.73)\end{array}$ \\
\hline Client-specific Controls & Yes & Yes & Yes & Yes & Yes & Yes \\
\hline Fixed Effects & $\mathrm{C}, \mathrm{Y}, \mathrm{AT}$ & $\mathrm{C}, \mathrm{Y}, \mathrm{AT}$ & $\mathrm{C}, \mathrm{Y}, \mathrm{AT}$ & $\mathrm{C}, \mathrm{Y}, \mathrm{AT}$ & $\mathrm{C}, \mathrm{Y}, \mathrm{AT}$ & $\mathrm{C}, \mathrm{Y}, \mathrm{AT}$ \\
\hline R-squared & 0.945 & $\begin{array}{c}0.697 \\
17362\end{array}$ & 0.888 & 0.945 & 0.697 & 0.888 \\
\hline
\end{tabular}

The table reports analyses of the relation between review partner tenure and audit effort. We measure audit effort for client $i$ in year $t$ using Audit Hours, Review Partner Hours, or Engagement Partner Hours. Our variable of interest, Review Partner Tenure, reflects the number of consecutive years that the review partner (RP) spends reviewing the engagement, and ranges from 1 to 5. For some analyses, we split Review Partner Tenure into five separate indicators marking the years 1 to 5 of the tenure cycle. RP Tenure Year 3 serves as base period and lacks a coefficient estimate. We include Partner Tenure and the same audit- and client-specific control variables and fixed effects as in Table 5. For all variable definitions, see Appendix A. The table reports OLS coefficient estimates and (in parentheses) $t$-statistics based on robust standard errors clustered by firm. $* * *, * *$, and $*$ indicate statistical significance at the $1 \%, 5 \%$, and $10 \%$ levels (two-tailed). 
TABLE B3

Descriptive Statistics on Non-Mandatory Rotations and Partner Tenure Prior to Audit Firm Switches

Panel A: Proportion of Non-Mandatory Rotations for Clients with Multiple PCAOB Inspections

\begin{tabular}{lc}
\hline PCAOB engagement profiles data: & $2006-2015$ \\
Inspection years & $>2,000$ \\
Number of inspected client firms & $>500$ \\
Number of client firms with multiple inspections & $51 \%$ \\
Of these, percentage of & $49 \%$ \\
Client firms with non-mandatory rotations between subsequent inspections (<5-year) & 3,333 \\
Client firms with only mandatory rotations (5-year) & \\
\hline Sample data: & $31 \%$ \\
Number of client firms (see Table 1 Panel A) & $69 \%$ \\
Of these, percentage of & \\
Client firms with non-mandatory rotations (<5-year) & \\
Client firms with only mandatory rotations (5-year) & \\
\hline
\end{tabular}

Panel B: Explainable and Unexplained Non-Mandatory Rotations

(1) Total non-mandatory rotations (see Table 1, Panel B)

(2) Explainable non-mandatory rotations:

- Retirement (dropping from dataset after more than 10 years as a partner) 197

- Promotion (title change to higher position or leadership role) 105

- Relocation (observable switch in office in subsequent year) 35

- Short-term break (partner rotates back after one or two years) 26

- Temporary replacement (partner fills in for one or two years) 16

Total explainable non-mandatory rotations

(3) Total unexplained non-mandatory rotations (1) - (2)

\section{Panel C: Partner Tenure Prior to an Audit Firm Switch}

\begin{tabular}{lr}
\hline \hline Audit firm switch when incumbent partner is in tenure years 1 through 4 & 374 \\
Audit firm switch when incumbent partner is in tenure year 5 & 57 \\
Total audit firm switches (see Table 1, Panel B) & 431 \\
\hline \hline
\end{tabular}

The table provides descriptive information on the sample of non-mandatory rotations and audit firm switches. A non-mandatory rotation occurs when the engagement partner leaves a client short of the regular 5-year rotation cycle (i.e., during years 1 to 4 of her tenure) and is replaced by another partner from within the same audit firm. Panel A gives details on the rates of non-mandatory rotations using an alternative data source. We identify non-mandatory rotations by comparing "engagement profiles" from client firms with multiple PCAOB inspections. In the engagement profiles that the PCAOB collects shortly before inspections, the audit firm indicates the lead partner's tenure year. Panel B provides details on how we identify plausible explanations for partners to rotate prior to year 5 of their tenure cycle. Panel $\mathrm{C}$ gives details on the tenure of incumbent partners at the time of an audit firm switch. We identify audit firm switches based on the opinion data in Audit Analytics. We do not include these partner changes in our count of non-mandatory (within-firm) rotations. 